Historic, Archive Document

Do not assume content reflects current scientific knowledge, policies, or practices. 



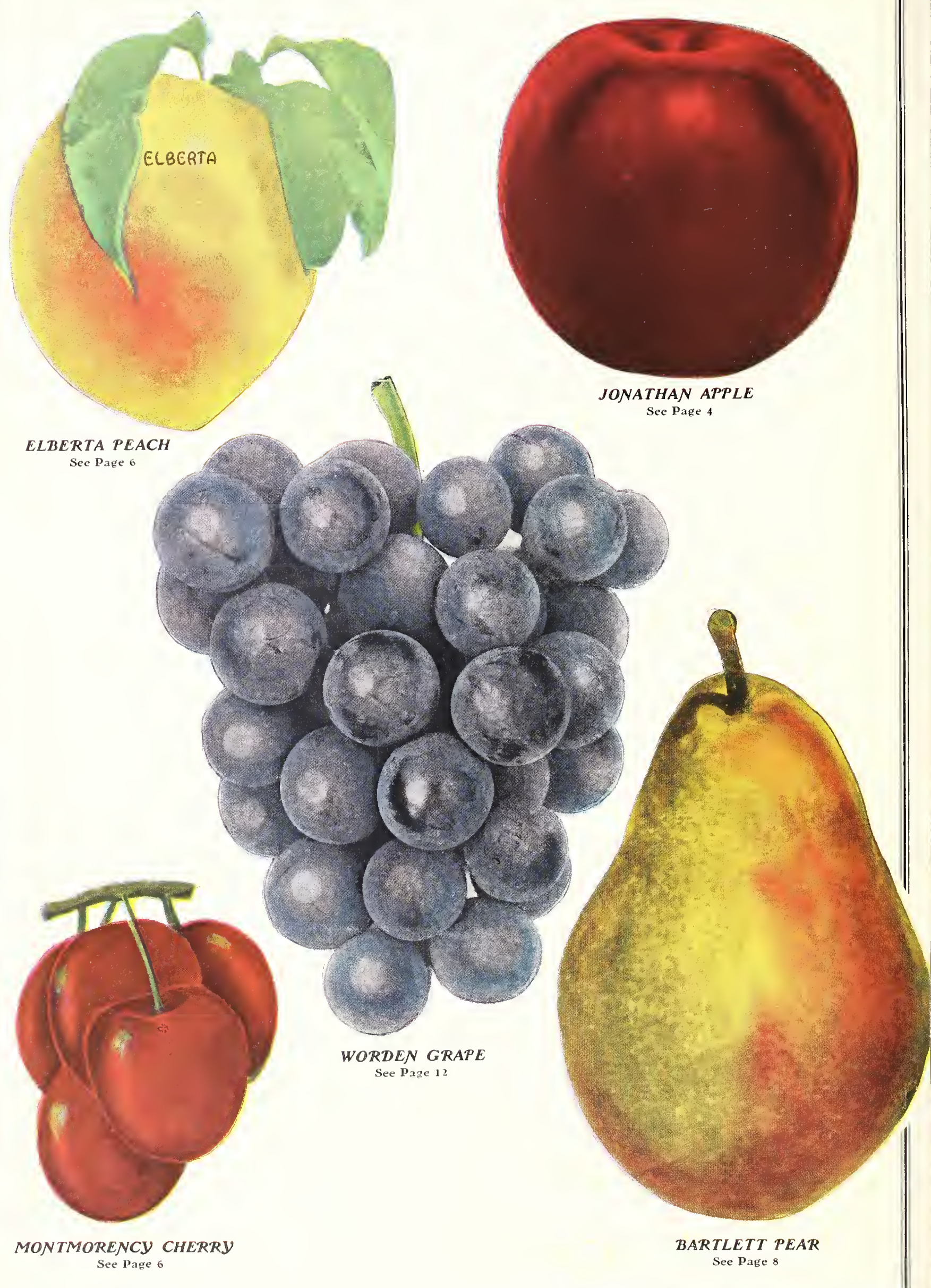




\section{Introductory}

It ls wlth great pleasure that we present herewith copy of "Weber's Gulde" for 1926 . First of all we want to extend rreetings and best wlshes for a prosperous year in 1926 and to thank each and every one of our customers for their patronage durlng the past years and hope that we may have the pleasure of recelving your valued orders for the coming year.

Those who may receive copy of "Weber's Guide" and who have never purchased Nursery Stock irom us, we ask that you give us a trial order.

We klndly ask those who receive copy of "Weber's Guide" to preserve same for reference. You wlll find much valuable informatlon contalned ln same. It would also be a great favor to us if you would show same to your friends who may be in need of something in our line. We are always glad to mail coples to interested parties upon request.

With prlces of fruit as high as they have been the past few years, it seems to us that the property owner should plant at least a part of his property to fruit of some kind suitable to his locality and not depend entirely upon farm crops. Diversifled farmlng ls the money-making proposition today.

Our facllities are the best of any nursery near St. Louis; we have large frost-proof concrete storage houses, 80 by 120 feet, 14 feet high, also storage cellars for bulbous stock. Our greenhouses cover over one-half acre and our cold-frames in whlch we keep our Perennial plants cover about 1 acre, so that we are prepared to handle your orders carefully.

All packing and filling of orders is personally superintended by members of the firm in the best possible manner; no dlstance ls too great for our mode of packing. For spring shipments we carry a complete line of stock ln our storage houses and can make shipments at any time during the winter and up to May 1st, and later according to weather conditions. In etc.

We extend a cordlal Invitation to visit our Nurseries, We, however, wish to announce that our offices wil be closed all day Sunday excepting during the months of october and November, also March, April and May,
when we will have open Sundays from 8 to $11: 30$ to accommodate those who cannot come during the week.

Solicitlng your correspondence, lnquiries and favors, we are

Yours truly.

\section{H. J. WEBER \& SONS NURSERY CO., INC.}

Established 1867.

Incorporated 1903.

Capltal, \$150,000.00.

100 Acres in Nursery

LOCATION - Nurseries and office located on Gravois Road, one and one-quarter miles west of the St. Louis City llmits nine miles southwest of the St. Louis Court House, and one and one-half miles west of the terminus of the Cherokee Street
Car Line. We are one-half mile east of Gravois Station on the St. Louis, Cape Girardeau \& Memphis branch of the Frisco R. R. We now have an Auto Bus Line leaving end of Cherokee car line passing by our office. Phone us for time of leaving.

\section{Terms, Conditions and General Remarks READ CAREFULLY BEFORE MAIING UP ORDER}

Clause 1-Terms invariably cash.

Clause 2-Remit by Postofice or Express Money Order on St. Louls, Mo.; Reglstered Mail to Afiton, Mo., or by Draft. Please do not send private checks unless drawn on some
St. Louis Bank. Address all correspondence to H.J. Weber \& Sons Nursery Company, Afton, Mo. in cash.

C. D. D. Orders must be accompanied by one-half the amount

Clause 3-Quotations. Prices quoted in this catalogue are for the quantities specified. 1,2 or 3 trees or plants of a kind are to be figured at the single price, 4 or more plants of a kind are to be flgured at the 10 price, 40 trees of a kind at the 100 price. Example: 1 Oldenburg, 2 Wealthy, 3 Grimes, 2 Winesap, 2 York Imperial Apple are to be figured at the single price. If you take 4 trees of each variety mentioned above you are entitled to the a variety, you will be entitled to the 100 price, and so on throughout the catalogue. Thousand prices will be quoted on application where list of varieties accompanies the request. All orders are booked with the understanding that same shall be void should injury befall the stock from drouth, fire, hail, frost or other causes beyond our control.

Clause 4-Non-Warranty Clause. If nursery stock proves untrue to the name under which it is sold by us, a replacement of th stock, as originally ordered, without charge, or a refund of the purchase price shall be a complete satisfaction of our liability. Except for such liability, we give no undertaking or warranty, express or implied, as to description, quality, growth, productiveness, or any other matter on any nursery stock we sell. We assume no liability for delays in delivery, or for non-delivery of nursery stock caused by frost, fire, flood, drought, hail, strikes, embargoes. war or other causes beyond our control. our re: embargoes. war or other causes beyond our control. Our responsibility ceases upon the delivery of stock in good condition. Complaints, if any, must be made within five days after delivery. sponsible for losses in case of delay or damage in transit.

Clause 5-Free Packing. We pack free all orders sold at catalogue prices, in the best possible manner, in bales or boxes with moss or excelsior.

Clause 6-No Cartage to freight depots, express offices or wharves in St. Louis.

Clause 7-Clty of St. Louls and Suburban Dellverles. Our delivery trucks will make trips to the various sections of $\mathrm{St}$. Louis and suburban points during the seasons. Orders to go this way must be left entirely to us as to the time of delivery. We

Clause 8-Speclal Dellverles. Parties desiring delivery on a certain day must order "Express Shlpment" of their order
and must pay Express charges. Ordes must be plainly marked
"Special Dellvery," and must give date on which delivery is to be made, weather conditions permitting.

Clause 9-Railroad Facilltles. We have the St. Louis and Memphis $R$. R. branch of the Frisco System within one-half mile of the office. Our station is Gravois, Mo. Carload shipments are loaded here. This with the St. Louis facilities enables us to make prompt shipments on direct lines.

Clause 10-Early Orders. Customers should send in orders as early as until the last minute and then expect to get immediate delivery. Wishing to serve our patrons in the best possible manner is the reason we ask for early orders.

Clause 11-Dlrectlons. Observe carefully that your Name, Postofice, County and State are plainly written on your order; also state whether to be sent by freight or express, and by what route. If no directions be given, we will use our best judgment. Use order sheet enclosed.

Clause 12-Errors. Any errors that may occur in fillng orders must be reported within flve days after recelpt of goods. We will immediately correct same. Complaints entered after the above stated time will not be entertained.

Clause 13-1-Losses. All stock will be sent out in good condition. We do not guarantee stock to live, nor do we make up any losses whatever due to climatic conditions or after culture on the part of the purchaser. Immediately upon receipt of stock, open the package and ascertain the condltion of same; check up the varleties and compare with your order and report to us at once any complaints that are to be made. If package has become frosted or dry en route, treat as per instructions given under "Directions for Transplanting and Care of Trees, Shrubs, etc."

Clause 14-Replacing. We do not replace stock that may dle at the prlce quoted in this llst. Our responsibillty ceases upon the delivery of stock in good condition. Complaints, if any, must be made within five days after delivery, when we will at once rectlfy or allow deductlons. We will not permit any deductions from invoices unless the above conditions have been complled with.

Clause 15-Insurance. A great many people want the nurseryman to stand all the losses, whether due to climatic conditions, planting, after care, etc. For such customers we have declded to offer an insurance proposition, as follows: If the purchaser desires insurance on stock purchased, we will insure the growth chaser desires insurance on stock purchased, we will insure the growth of such stock as we may deliver (excepting injury sustained by fire, and floods) until the first day of september after delivery; provided and floods) until the first day of September after delivery; provided that purchaser adds twenty-five per cent $(25 \%)$ to the amount
of the purchase price and pays the total amount on or before the day of the purchase price and pays the total amount on or before the day chaser is to notify us promptly on the first day of September as to chaser is to notify us promptly on the first day of September as to under no conditions are dead trees or plants to be removed until we have had an opportunity to investigate in case we should desire to do so. 


\section{Terms, etc.-Continued}

Clause 16-Sulbstitution. It is customary, should the supply of a variety become exhausted (as will occasionally occur in all eatabllshments), to substitute in its place a similar sort, if there your order, "No substitution."

Clause 17-Selectlons. Persons not acquainted with the different varieties can leave the selection to us, in which case we will select as if planting for ourselves.
Clause 18-Tramsportation. Fvery care is taken to secure safe and prompt transportation. The forwarders alone must be
held responsible for loss or delay in transit.

Clause 19-Inspection. Our nurseries are annually inspected by the State Entomologist and have been found free of San Jose tifleate of inspection will be attached to overy package that cerour establishment.

Clause 20-Notice. The prices in this list abrogate previous quotations and are made on stock to be strictly first class in the
grades named. Please do not compare our prices with frms quoting grades named. Please do not compare
on mailing size trees and plants only.

\section{Directions for Transplanting Trees, Shrubs, etc.}

Preparation of the Soll.-For fruit trees the soil should be dry, either natural or made so by thorough drainage, as they will not live or thrive on a soil constantly saturated with stagnant moisture. The soll should be well prepared by plowing at least twice beforehand, using a subsoil plow after the common one at the second plowing. On new, fresh land manuring will be unnecessary, but on lands exhausted by cropping, fertilizers must be applied, elther by turning in heavy crops of clover, or well decomposed manure be in as good condition as for a crop of wheat, corn or potatoes.

Preparation of the Trees Refore Planting--This is one of" the most important operations to be performed, and one in which the most fatal errors are liable to be committed. The object of pruning is twofold: First, to secure a head properly shaped and the fruit. Second, to prepare the natural balance between the roote and branches of the trees, that a healthy growth may be secured. When young trees are removed from the nursery, roots are often broken or bruised, as will be the case however careful the digging, packing and transportation may be performed, and it becomes necessary that the balance should bo preserved by a proper and judiclous pruning. This pruning should be adapted to the size and condition of the tree, and at the same time the form should not be forgotten. It should be so close as to enable the roots to supply the demand for sap from the remaining branches, and at the same time, no growth already secured should be wasted.

In both Standard and Dwarf Trees, it will be usually found rule to cut back, when pruning at transplanting, one-hal of the growth of the provious season. The ends of the large roots should be made smooth with a sharp knife, where they have been roughly cut with the spade in digging, always cutting from the
bottom of the root with an outward cut New roots will form, and the injured parts heal more readily with this attention.

Planting with Dynamite. - We recommend the use of $\mathrm{dy}$ namile to every plan

1st. It is more economical than any other method.

2nd. It costs little or any more than digging a proper sized hole with the spade.

3rd. Dynamiting the soil conserves moisture and prevents the big losses during dry seasons that are common with spade-dug holes.

4th. Trees planted with dynamite make as much growth in years as spade-set trees will in four years.

5th. Dynamite breaks up the ground for 12 to 15 feet in diameter and 5 feet deep, kills all insects and fungous growth contained in the soil.

6th. Dynamite-set trees bear fruit one to two years sooner han spade-set trees, and live longer.

W rite to the E. 1. DuPont Nemours Powder Co., Wllmington,

"Tree Planting" with dynamite.

Planting with Spade.-The holes should be dug large enough In the first place to recelve the roots of the trees without cramping or bending them from their natural position. The tree having been properly pruned, should be held upright and the earth filled in around the roots, the finest and best soil from the surface being fully in contact with it. When the hole has been half filled, pour in a pall or two of water: let this settle well, then finish the plantlng in a pail or two of water: let this settle well, then finish the planting what higher than elsewhere, and press the soil carefully down with What higher than elsewhere, and press the soil carefully down with the foot. Care must be taken against planting too deep; when the when in tbe nursery. When set in Autumn, it is well to raise a mound of earth them from being swayed by the winds or thrown out by the frost during the winter. It should be removed in the spring. In planting 1 warf trees, the stock on which they are budded should be under ground.

Staking-- If trees aro tall or in exposed situations, they should be supported by stakes to prevent injury from the action of the wind. Staking is done in the best manner by driving two strong stakes firmly in the ground, one on each side of the tree, about a foot distant from it, and fastening the tree between them with upright position without chaffing until the roots obtain a firm hold upon the soil.

Mulching.-Thls is properly done by placlng a layer of coarse manure or litter from three to six inches deep about the tree, extending one to two feet further in each direction than the roots. This kesps the ground moist and of equal temperature, rendering watering unnecessary, and is in all respects preferable to it. Trees properly mulched are more certain to live and

Cultivation After Planting.-Here is the grand opportunity for the success of the skillful fruit grower. It is not enough for him that his trees are of the choicest sorts. selected with regard to the climato and adaptation to the uses for which they are designed; that they are properly pruned and planted in dry, mellow soil, thoroughly enriched and prepared for their reception; protected shape and thriftiness. He knows very well that all this may be properly and well done, at great expense, and without further care be followed by an entire failure, so he watches their growth and defends them from their enemies that the cankerworm and caterpillar do not find safe lodgment among the branches; or the borer cut about them or the cattle obtain access to them by neglected gates or fence, and break down the branches. He is well repaid, for they and smooth, and soon a most abundant crop of superior fruit testifies to his wisdom and care. His neighbor, perhaps with better soil neglected these apparently trivial but really important matters sees, instead of thrifty trees loaded with luscious fruit, the wreck of his hope in a few mossy, scraggy, misshapen specimens of what he his hope in a few mossy, scraggy, misshapen specimens of what he considers his ill-fortune, and hastens to remove. He. too, is justly
rewarded for his neglect, as is his more prosperous neighbor for care. Those who are obliged to plant trees in a fleld of grain or grass should see that all such are carefully mulched with rough manure, hoed crop is greatly preferable in such plantation for the first five hoed crop is greatly preferable in such plantation for the first five and plum trees will grow and produce fairly in turf. The dwar. trees and peaches should be well mulched every year with loose manure and the ground thoroughly cultivated. They will amply
repay for this attention in the increased quantity and improved repay for this attentio
quality of the fruit.

Pruning.- Pruning after the first vear should be varied acshould be trimmed as early as possible up to the height it is intended the future head should be, and the cutting off of large limbs may not the future head should be, and the cutting off of large limbs may not
in the future be necessary. The removal of large branches should be avoided in all cases whenever it is possible to do so, as decay is be avoided in all cases whenever it is possible to do so, as decay is liable to commence at the point of separation and extend into the
trunk; whenever it is done the wound should be carefully pared trunk; Whenever it is done the wound should be carefully pared smooth and a coating of paint or grafting wax applled to protect until the head has reached the desired height, the only pruning needed is to remove such branches as are crossing and interfering needed is to remove such branches as are crossing and interfering with each other, and keep the heads in a symmetrical shape and well open to the sun and air. Trees should receive proper shape by judicious pruning and attention early in the spring of each year, while they are young, and very little pruning will be necessary afterward.
When trees are to be pruned and trained for snecific purposes and in a special manner, the orchardist will find full directions in the stand ard works on horticulture which may be read with great benefit and follow

Grape VInes require a dry, mellow, well-drained soll, deeply worked and well enriched, with a warm, sunny exposure. In planting, give the roots plenty of room and settle soil firmly about them. All newly planted vines should be cut back to 2 to 3 buds or eyes as soon as planted. Two sprouts or canes should be aliowed to grow the following summer and should be carefully tied to stakes to grow the following summer and should be carefully tied to stakes following winter these canes should be cut back to five feet and tled following winter these canes should be cut back to five feet and tled to the lower wire of the trellis, which should be put up the following fall or winter after planting. For the subsequent pruning of vines work on the subject.

Berries should have a strong soll and be kept under constant cultivation. Mulching is of special value. Raspberries and Blackberries should have old wood cut out each year and new canes pinched of when three feet high. Strawberries should be mulched late in the fall: uncover the crowns early in spring; $r$

Currants and Gooseberries need heavy mulching and pruning, so that new wood will have room to grow

Roses should have a deep, rich, well-drained soll, and should be severely pruned every spring before the buds start, cutting back all the last growth to three or four buds, except climbing roses, which may be first allowed to partly cover the space deslred. Old decayed branches should never remain. Every autumn compost
should be placed around the stems of the plants and spaded into the ground in the following spring.

Treatment of Trees That Have Been Frozen in the Packages, Recelved During Frosty Weather, or After Long Exposure. Place the package, unopened, in a cellar or some such can be unpacked and either planted or placed in a trench untll convenient to plant. Treated thus they will not be injured by the freezing. If dried from long exposure, bury entirely under the ground, soaking well with water, or place in wat
hours, and prune more closely than ordinarily. 


\title{
A COMPLETE SPRAY CALENDAR
}

\author{
For Winter and Summer as used and recommended by the B. G. Pratt Co., New York, \\ Manufacturers of Scalecide and Sulfocide
} (Never omlt "Standard Sprays"" and add the "Speclal Sprays"
as needed.)

After ten years of comparatlve work wlth most of the bestknown commercial sprays, we have settled on the following spraying program in our own large orchard operations as giving the best results obtainable. Using this program, we have packed $95 \%$ A-grade apples from tree-run without thinning.

In the last few years many of our friends and customers have followed it with most gratifying results.

Mr. George T. Powell of Ghent. N. Y.. Writes: "Never produced a crop of apples of so fine a quality." " "It seems that every. My apple trees are the finest in this locality as well as the apples."

\section{FIRST STANDARD SPRAY. \\ (Dormant or Scale Spray.)}

For Apples, Pears, Quinces, Cherrles, Peaches, Plums and Smail Fruits.

Spray any time in the fall after the leaves have fallen and the wood has hardened, or in the spring before the buds show green, providing it is not too cold, say $40^{\circ}$ Fahr., using "Scalecide," 1 gallon to 15 gallons of water (3-50). Spray thoroughly from the topmost twig down to the base of the tree at the ground, using tarts to drip.

It is well to let the material run down around the base of the tree, as lt alds in controlling diseases and insects there.

Make the fall application for pear psylla and peach leaf curl. Make the delayed dormant application for aphis, pear thrips, leaf roller and tent caterpillars Make either fall or spring application for scale, bud moth, case-bearer, cankers, both fungous and blight and collar rot.

Be sure your spray-tank is clean before you start to spray.

SPECIAL SPRAY NO. 1.

Sometimes called the "Scab," "Cluster-bud" or "Pink" spray, and is almost becoming a Standard Spray.

\section{For Apples, Pears and Quinces.}

When the buds are still in cluster, just before the blossoms begin to show color, use "Sulfoclde" 1 gal. to 200 gallons of water. wlthout any poison.

For chewing insects use arsenate of lead or cal-arsenate combined with Sulfocide, one heaping teaspoonful to each gallon of spray ( $3 / 4$ of a pound to 50 gallons). Dilute Sulfocide, 1 quart to 50 gallons of water. Cal-arsenate may be combined with Sulfocide with or without Kayso. When arsenate of lead is used be sure to follow these directions: Use the same quantity of Kayso as of arsenate of lead: mix Kayso in the water first, arsenate of lead second, and Sulfocide last, after all the water has been added.

For Peaches, Plums, Apricots and Stone Fruits.

When the buds are ready to open and just show color, use "Suifoclde," 1 gallon to 200 gallons of water. Use soap or Kayso as a spreader

A poison spray at this time is usually not necessary on stone rruits, but if it is desirable use the Kayso, arsenate of lead and of lead to 200 gallons of water is all that is considered safe on stone fruits. Never use cal-arsenate on stone fruits.

\section{SECOND STANDARD SPRAY.}

For Apples, Pears and Qulnces.

For the control of Codling Moth (wormy fruit) and pungous troubles, but generally too late for scab.

This spray is most important and should never be omitted or delaved, and must be very thorough.

As soon as the bees leave the blossom, and not later than ton days after the petals fall, spray with one pound of Kayso, one pound of arsenate of lead and one quart of Sulfocide to 50 gallons of water; or $1 / 2$ pound of Kayso, one pound of cal-arsenate and one quart Sulfocide to 50 gallons of water. Follow directions caresulfocide last, after all the water has been added. Ncver spray in full bloom. Direct the spray into the open calyces.

For Peaches and Stone Frults.

Just as the shucks or withered blossoms are falling from the newly-formed fruit, spray with $3 / 4$ pound Kayso, 3/4 pound arsenate of tions carefully: Always mix Kayso in the water first, arsenate of lions carefully: Always mix Kayso in the water first, arsenate of lead second and Sulfocide last, after all the water has been added. This spray is for brown rot and for curculio, the little insects that
sting the peaches and plums and make wormy fruit. Never use calsting the peaches and plums and make worm
arsenate on peaches, plums or stone fruits.

For later spraying of peaches, plums, cherries and apricots, use sulfocide and soap alone every few weeks until picking time Peaches Sulfocide and soap alone every few weeks until picking time. Peaches ing, will keep in marketable condition five to ten days longer than where not sprayed. The spray material does not show on the fruit, cannot be tasted and is non-poisonous.

SPECIAL SPRAYS NO. 2 and NO. 3.

Where leaf spot or black rot is prevalent, or a late batch of codling moth is feared, repeat Second Standard Spray ten days later, and for the second brood, slx weeks after the petals fall.
ORANGES AND CITRUS TREES.

"Scaleclde" has been used for many years for the control of scale insects on cltrus trees.

Use "Scaleclde" 1 to 50 or 60 parts of water during the dormant season as you would Lime-Sulfur for scale. Repeat as often as necessary. For white fly, rust mites, etc., use one gallon of Sulfocide and two gallons of Scalecide to 200 gallons of water-mix Sulfohas also proven very effective for the control of citrus scab and citrus aphis.

EVER GREENS AND CONIFERS.

Spray with "Scaleclde," 1-25, just before the new growth starts in the spring.

\section{SPRAYING SMALL FRUITS.}

Grapes, Currants, Gooseberrles, Raspberrles and Blackberries.

Never omit a dormant spray with "Scaleclde," 1 gallon to 15 gallons of water, before the leaves come out-it. will repay many times the cost and trouble. It cleans them of many insects and diseases, making the summer spray with "Sulfocide" more effective.

Spray just before blossoming with "SuIfoclde," 1 part to 200 parts of water, and again when the fruit sets and as often as occaslon demands.

Add soap or Kayso as described under spraying peaches. lnsects.

Dust with 1 part Cal-Arsenate and 2 parts Lime for chewing

\section{SPRAYING VEGETABLES.}

We spray everything ln the garden subject to fungi once every two weeks according to weather conditions.

Beans, tomatoes, eggplant, peppers, cucumbers, squash and melons should be sprayed every ten days or two weeks from the tlme they start through the ground with "Sulfoclde," 1 gal. to 200 gallons of water (one quart to 50 gallons, or one ounce to $\mathrm{j} / \frac{2}{2}$ gallons water). For chewing insects use $3 / 4$ pound of cal-arsenate or arsenate of lead to 50 gallons of water. When combined with Sulfocide, cal arsenate can be used with or without Kayso. But if arsenate of lead is used, use an equal a mount of Kayso and follow the directions: Mix Kayso in the water first, arsenate of lead second and Sulfocide one part cal-arsenate and two parts hydrated or slacked lime.

"Sulfoclde" has been used for years by the vegetable growers of Florida with wonderful results: String heans and tomatoes are sometimes dlpped in "Sulfoclde" after picking to insure safe arrival at market.

Several years ago two men planted three acres of beans together. One wanted to spray and the other did not, so the patch "Was divided in two equal parts. The man who sprayed with spray picked only 36 hampers. (Address furnished on request.)

\section{SPRAYING POTATOES.}

We have not had occasion to use any other fungicide on our potatoes for ten years.

Potatoes require a little stronger mixture than other vegetables. Use one gallon of Sulfocide and six pounds cal-arsenate to $150 \mathrm{gal}$ lons of water (with or without Kayso). Or use arsenate of lead instead of cal-arsenate, but be sure to use an equal quantity of Kayso mix Kayso in the water first, arsenate of lead second and Sulfocide last, after all the water has been added. Start when the vines come

through the ground and keep the new growth covered. Sulfocide to 200 gallons of water and then add two gallons of Scalecide. Do not use any poison with this combination.

\section{SPRAYING FLOWERS.}

For mildew and blight on roses, hollyhocks, carnations, chrysanthemums, peonies, etc. spray with 2 ozs. of "Sulfocide" to 3 gals. of water ( 1 part to 200 parts of water) every ten days or two
weeks to which a little soap is added. If 2 ozs. common laundry soap is softened by boiling and added to each 3 gals. "Sulfoclde" spray, it will spread better and leave practlcally no marking on rose leaves.

If Aphis are present, add 1 teaspoonful Black Leaf 40 to each gallon of spray. "Sulfoclde and Scaleclde" as recommended for potatoes and fruits, cannot be used on roses and some flowers.

\section{PROPORTIONS FOR MEASURING SMALL QUANTITIES}

One ordinary cup or tumbler $-80 \mathrm{oz}$. or $1 / 2$ pint or $1 / 6$ of a quart.

1 teaspoonful to $1 \frac{1}{2}$ qts. water or 6 cupfuls.

$1 \mathrm{oz}$, to 6 qts. water (1 $1 / 2$ gals. $)$

1 cupful $(8 \mathrm{oz}$.) to $121 / 2 \mathrm{gals}$. Water.

1 pint to 25 gals, water.

2 quarts to 100 gals. water.

CAL-ARSENATE AND ARSENATE OF LEAD.

One heaping teaspoonful to 1 gal. of water makes approximately the proportion of 3 lbs. to 200 gallons of water

We are the Western Distributing Agents for "Scaleclde" and "Sulfoclde," for the B. G. Pratt Co., New York, N. Y., and Hackensack, $N$,

Write us for booklets and price list on Insecticides. 


\section{Fruit Department}

ATTENTION, BUYERS OF NURSERY STOCK:

Please note that we specify age, caliper and approxlmate height of our fruit trees; there is no order.

\section{STANDARD APPLE}

Our supply of 2-vear apple for spring 1926 delivery will be limited. and on account of the heavy demand we kindly ask our patrons to place their orders promptly upon receipt of this catalogue.

PLANT standard apple trees from 30 to 40 feet apart each way, according to the nature of the soil.

At 30 feet apart it takes 48 trees per acre; 40 feet apart it takes 27 trees per acre.

Extra selected trees

2 -year, $11 / 16$ to 1 inch, 5 ft. and up.

2 -year, $9 / 16$ to $11 / 16,4 \mathrm{ft}$. and up..

\begin{tabular}{rrr} 
Eacl & 10 & 100 \\
$\$ 0.90$ & 10 & \multicolumn{1}{c}{100} \\
.70 & $\$ 6.00$ & $\$ 50.00$ \\
.60 & 5.00 & 40.00 \\
.55 & 4.50 & 35.00
\end{tabular}

\section{SUMMER OR EARLY VARIETIES}

Eariy Harvest.-Medium to large, flat, pale yellow; good. Tree a fair grower and bearer. July.

Fameuse (Snow Apple).- - Iedium to large; a handsome, deep crimson, white-fleshed apple of high flavor and best quality; very productive. August and September.

Oldenburg (Fussian).-Medium to large; striped, mostly red. Best summer cooking apple; tree hardy, early and a good bearer. July and August.

Red Jume.-Medium size, red; flesh white, tender, juicy, subacid: an abundant bearer. July.

Yellow Transparen (Russian),-Skin clear white changing to pale yellow when fully ripe; flesh white, tender, spriglitly subacid; good early bearer. July.

\section{AUTUMN VARIETIES}

KIng David.-A beautiful apple, resembles Jonathan in color. Tree strong, vigorous grower, healthy, bears young. September

Maiden Biush.-Large, flat, pale yellow; beautiful blush mild, sub-arid: valuable for market, cooking and drving. September

Wealthy.-Fruit medium, oblate, skin smooth, whitish-yellow. shaded with deep red in the sun, splashed and spotted in the shade. Flesh white, tender, juicy, sub-acid, very good. August to September.

\section{EARLY WINTER VARIETIES}

Grimes.-Medlum to large, roundish, oblate, slightly conlcal, arge specimens oblong. Skin yellowish-white. with a mild sub-acirl agreeable good to best flavor. September to December.

Jonathan.-Medium size, unless thinned on tree, when it becomes a air size; form roundish, conical; skin thin and smooth the ground clear, light yellow, nearly covered with lively red stripes and deepening lnto brilliant or dark red in the sun: flesh white, rarely a little plnklsh; very tender and juicy; mild, sprightly vinous flavor. September to December.

\section{WINTER VARIETIES}

Arkansas (Mammoth Black Twig).-A seedling of Winesap, which it resembles in every way except that the tree ls a better and much more vigorous grower, more hardy, and the fruit is much larger. Color dark red; flesh firm; flavor mild. A good keoper. One of the best. October to May.

Balley's Sweet.-Tree hardy, vigorous, upright, spreading, productive. Fruit large, roundish, conical, color yellowish shaded and slightly stripod with red. Thickly covered with small dots. Flesh white, tender, with a honeyed sweet flavor. Good. November to March.

Arkansas Black.-Large, very dark red, smooth, roundish flat, lightly dotted white; flesh yellow, sub-acid; long keeper. November to April.

Newton Pippin.-Fruit medium, oblate, slightly conic, yellow. Washed with light red, richly splashed with deeper red. Flesh yellow, crisp, tender, with a rich vinous flavor. October to February.

Biack Ben.- Of the Ben Davis type, sald to be better than Gano. Fruit large, deep red, long keeper, good shipper and sells well on the market. September to February.

Dellcious.-This variety should be in every orchard. Fruit large, almost covered with beautiful dark red, blending to yellow at the blossom end. Sweet, pleasant flavor, only enough acid to
make lt pleasing. Flesh crisp, Juicy, flne grained, melting. Sepmake lt pleasing.

Ben Davis.-Large, roundish, oblong, red striped, very handsome. Mild, sub-acid, not rich. Tree very vigorous, hardy and productive. This is one of the safest and most profitable market apples grown in this country at present. October to March.

Gano.-Tree very healthy, vigorous, hardy, having stood 32 degrees below zero without injury. A rapid grower, large and spreading in orchard. Color bright red without stripes or blotches.
Similar but superior to Ben Davis. Large and even in size. Proliflc bearer and a good keeper, October to March.
Northwestern (Greening).-A Wisconsin seedling of great promise, having taken first prize at their State societies. good grower and hardy. Fruit yellow, smooth, rich, of good size, November to December.

Rome Beauty.-Large, roundish flat; bright red, mild, subacid, very good. A good grower and early bearer, November to March. Spitzenburg (Esopus), - Large, round, brilliant red, with gray
dots, Flesh flrm, rich, crisp, juicy, delicious, A fine apple where it succeeds. October.

Stayman.-Tree ls a vigorous grower, drooping in habit and adapts itself to soils and situations; fruit large size, bright red color and produced in large quantities. A profitable market variety. October to March.

Winesap.-Medium, conical, dark red; very smooth, Acid to sub-acid, juicy and rich, very valuable for both family and market. Tree very hardy and an early and constant bearer. December to April.

Huntsman.-Fruit large, flat, deep yellow: very mild, subacid, fine-grained. Very good. Valuable for family and market. Tree fair grower and good bearer, but does not bear heavily while young. october to April.

Yellow Bellflower--Large to very large; oblong, pale yellow, sometimes blushed; acid to sub-acid, rich and good. Tree a fine spreading grower and hardy. October to January.

York Imperial.-Medium to large, oblate; color white, shaded with crimson; flesh firm, crisp, juicy and sub-acid; a good bearer and keeper; one of the best winter apples. November to April

Janet (Rawles).-Also called Geneton. Medium to large when grown on good soil and not allowed to overbear; flat, conical striped, red, sub-acid; very good for market and family use. Good cider apple. October to April.

\section{CRAB APPLES}

Same price as Apple.

Florence.-Originated in Minnesota. Fruit medium in size; color carmine when well colored; flesh yellowish, fine, acid. Excellent for cooking and for jelly. Valuable for early market. Tree hardy and spreading; bears when young and inclined to overbear.

Transcendent.-Medium size; flavor pleasant and agreeable: extremely hardy.

Hysiop.-Large size, beautlful dark crlmson. Hangs in clusters. September.

\section{A Table Showing the Number of Trees or Plants to the Acre.}

Distance.

No. of trees.

$\begin{array}{llll}1 \text { foot apart each way. } .43,560 & 12 \text { feet apart each way. . } & 302 \\ 2 \text { feet apart each way. } 10,890 & 13 \text { feet apart each way... } & 257\end{array}$

$\begin{array}{lll}3 \text { feet apart each way... } 4,840 \quad 14 \text { feet apart each way... } & 222 \\ 4 \text { feet apart each way. } & 193\end{array}$

5 feet apart each way... 2,702 15 feet apart each way. . . 193

6 feet apart each way... 1,210 17 feet apart each way.... 150

7 feet apart each way... 88818 feet apart each way... 134

$\begin{array}{llll}8 \text { feet apart each way... } & 680 & 19 \text { feet apart each wa. ... } & 128 \\ 9 \text { feet apart each way... } & 537 & 20 \text { feet apart each way. . } & 109\end{array}$

10 feet apart each way... 43425 feet apart each way... 68

11 feet apart each way... $360 \quad 30$ feet apart each way... 40

Ruie-Multiply the distance in feet between the rows by the distance the plants are apart in the rows, and the product will be the number of square feet for each plant or hill, which, divided into the number of feet in an acre $(43,560)$, will give the number of plants or trees to the acre.

Distances for planting various fruits will be given under respective headings in this catalogue.
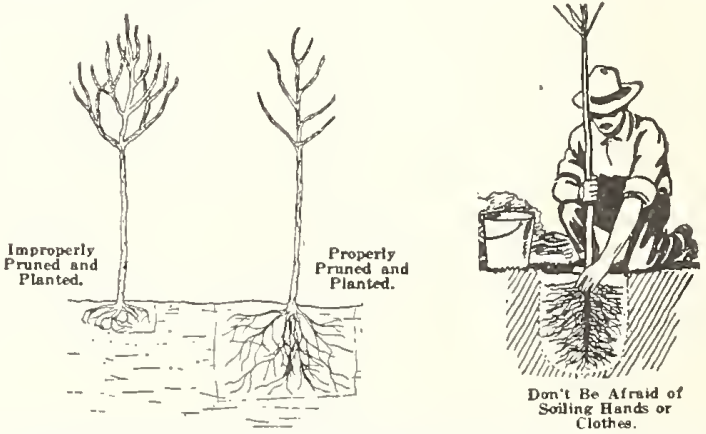

Proper planting and cultivation with correct pruning is the best insurance on an orchard. See page 2 for complete directions. 


\section{Weber's Collection Leading Varieties of Apple}
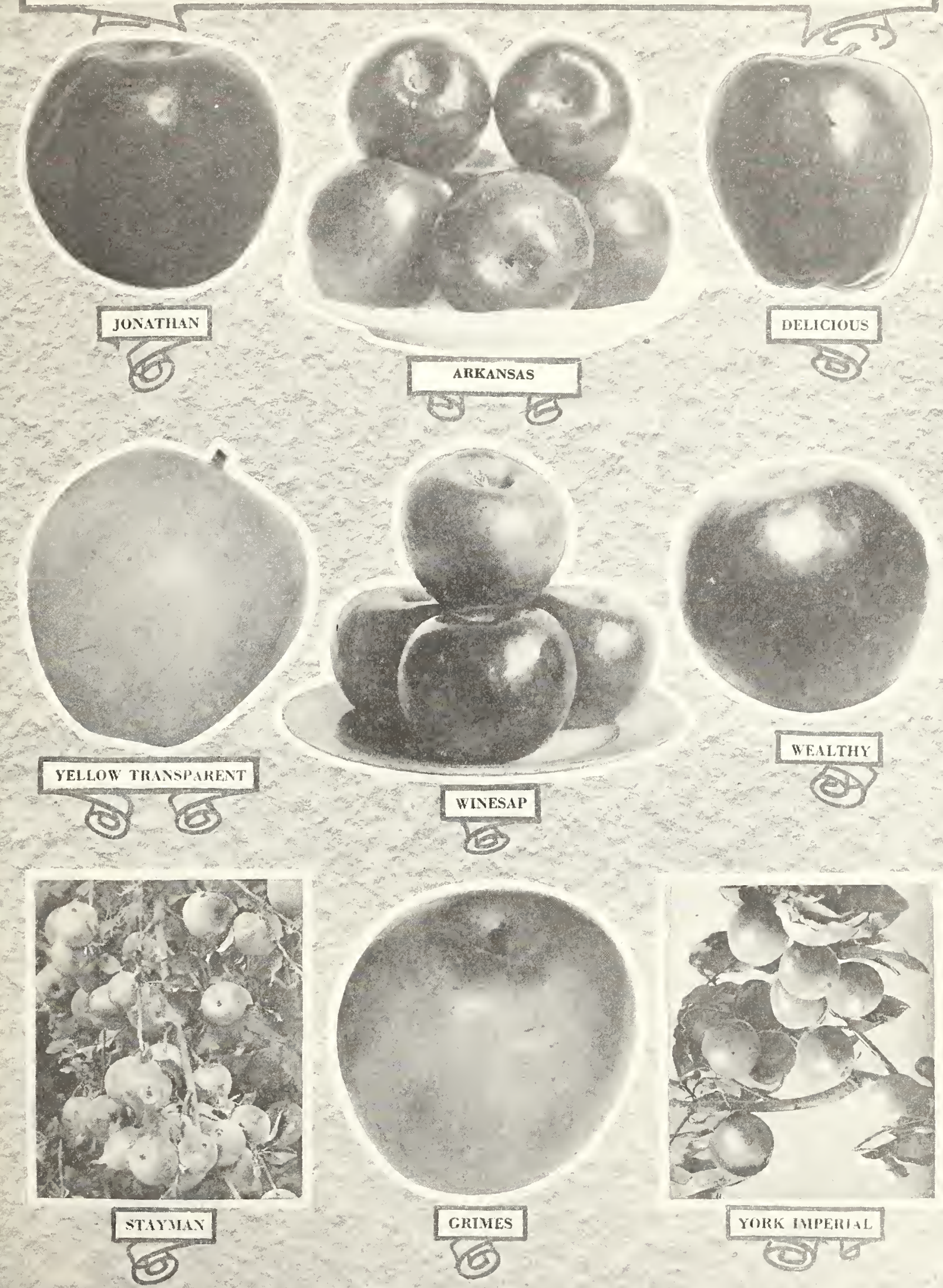


\section{Peach}

The Peach is probably the flnest of our frults; everybody delights ln the flavor of a fine, juicy Peach. In this section, select high, dry lands, northern or western exposure preferred.

In order to preserve the continued healthy growth of the trees and the fine quality of the fruit, the trees should have careful and severe

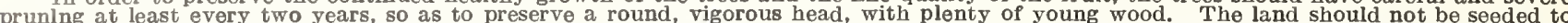

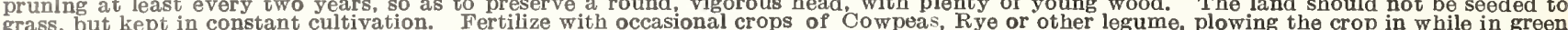

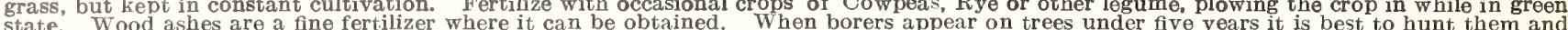

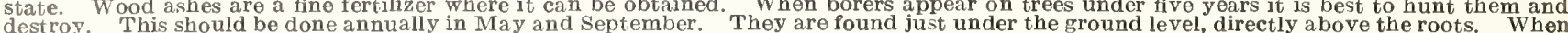

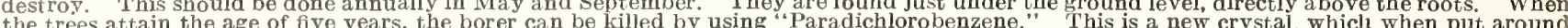

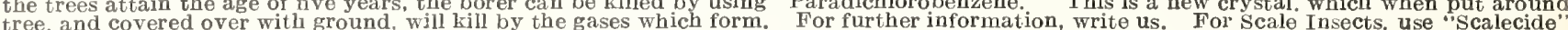

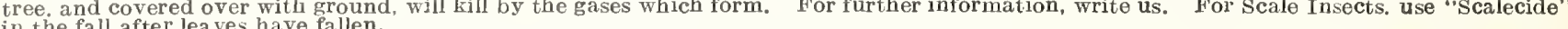
in the fall after leaves have fallen.

We have this year arranged our Yeach list as nearly as possible according to time or ripening. We think this will make it easier for our customers to make up their order, beginning with the earliest and on through the list to the latest

Plant Peach 20 feet apart, 109 trees to the acre.

-year, $11 / 16$ and up, 5 to $7 \mathrm{ft}$

$1-$ year, $9 / 16$ to $11 / 16,41 / 2$ to $6 \mathrm{ft}$

Each $10 \quad 100$

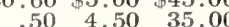
$40 \quad 3.50 \quad 25.00$

-Jear, $7 / 16$ to $9 / 16,31 / 2$ to $4 \mathrm{ft} \ldots \ldots \ldots \ldots$. $\ldots$ and and stock is limited. Place your order early while our stock ls complete.

\section{VARIETIES.}

Wheeler (Red Bird Cling).--Fruit larger than Greensboro. round, flesh white, juicy; tough skin nearly covered with deep red. A good shipper. July 1st to 5 th.

Mayflower--Originated in North Carollna; very early: color perfectly red; a valuable market sort.

Greensboro.-The largest and most beautlfully colored of the extra early peaches. A freestone: flesh white, julcy and excellent. July 10 th to 15 th.

Carman.-Large, resembles Elberta In shape; color creamy white, with deep blush; skin very tough; flesh tender, flne flavo and quite juicy. One of the hardiest in bud. In shipping qualitles and freedom from rot $1 \mathrm{t}$ is unsurpassed. Profltable market variety. July 10 th to 15 th.

Belle.-Very large; skin white, with red cheek; flesh white, Arm and excellent flavor: the fruit is uniformly large and showy: a very prolific bearer. July $15 \mathrm{th}$ to $20 \mathrm{th}$.

Mamle Ross (Cling).-Very large, oblong; color slmilar to Chinese Cling, but has more of a red cheek. With us one of the best early clingstones. July $20 \mathrm{th}$ to $25 \mathrm{th}$.

Rochester.-A new yellow freestone variety. The fruit ls large, yellow, sweet, juicy and of deliclous flavor, keeping and shipplng Well; skin prettly blushed. Tree strol

Crawford Early.-The best early yellow freestone; one of our oldest varietles. Rlpens about August 1st.

Champlon.-Originated at Nokomis, Ill. Flavor deliclous, sweet, rlch, juicy, surpasslng all other early varieties. Skin cream white wlth red cheek. Early.

Goldfinch (Ey. Elberta).-Color beautiful yellow, red on the unny slde; flesh juicy and sweet. August 10th to 15th.

Ede.-Large to very large; a rlch orange yellow; flesh yellow small stone; melting, rich, highly flavored. Freestone. August 15 th to $20 \mathrm{th}$.

Elberta.-Supposed to be a seedling of Chinese Cling, but ls entirely free. Very large, yellow, with red cheek; flesh yellow. frm juicy and of high quality; exceedlngly prolific; sure bearer and hardy. August 15th to 20 th.
J. H. Hale.-"Everybody has heard of this variety; ripens about the same time as Elberta; said to be larger and better flavored highly colored." We have only a limited number to offer this year. August 15 th to 20 th.

Wilma.-A splendid new varlety. In growth lt ls strong and stocky, with large, dark greon foliage. A seedling of Elberta; ripens about ten days later. Thls variety ls belng largely planted up in the Lake regions and is believed by many to be the comlng leading commerclal variety. End of August.

Rex (Late Elberta).-Almost identical with Elberta, but ripens several weeks later. Fine market peach, good shipper.

Crawiord Late.-Rlpens from 14 to 20 days later than the Crawford Early and Is larger in slze; color about the same, only a Preestones; moderately productive. August 25th to 30 th

Stump.- Very large, roundish: skin white, with bright red cheek: flesh white, juicy. One of the best late freestones. September 1st to 5 th.

Dulce.-Free, rich orange color, dark red cheek, firm, small seed.

Golddust. - A large, fine peach in every respect; color, bright yellow shaded with red; juicy, sweet; valuable for canning.

Picquet.- Large yellow with red cheek, Rich and sweet and a better flavor than Salway. Freestone.

Laura Cing. - Identical with Krummel's Late, only that it is a clingstone.

Pingold.-A good late clingstone.

Salway.-Large, creamy yellow, with crimson cheek; flesh deep yellow, juicy. rlch, sweet. September 15 th to 20 th.

Heath Cling.- One of the flnest canning peaches; good size; lemon shape: tree a good grower and excellent bearer. September 15 th to 20 th.

Krummel's Late.-Found in an orchard on property of Mr. Krummel of St. Louis. Color a rich golden yellow, with bright red cheek; round; free-stone; juicy. Ripens here about October

$5 \mathrm{th}$, and is a good keeper. purple. Originated on the grounds of Judge Hugo Muench of St. Louis. We recommend it as the best late yellow cling. October 5 th to 10 th.

Greblng Peacli. $\rightarrow$ Originated on the farm of Grebing near Perry large, almost round, free-stone: color, white in shade, blending into a beautiful red, thence to a very deep red, almost black, where exposed to full sunlight; something on the order of Mountain Roses, only darker. Flesh white, juicy, vinous, melting. Small stone. Tree a tremendous bearer, hardy in fruit, bud bearing when others fail. Fruit should be thinned and trees kept under cultivation, with proper a limited number of trces to offer this year. Ripens in July. Price, $\$ 1.00$ each; three trees for $\$ 2.00$.

\section{Cherry}

The Cherry is one of the finest and most delicate dessert fruits. The acid varieties are also highly esteemed for preserving and cooking

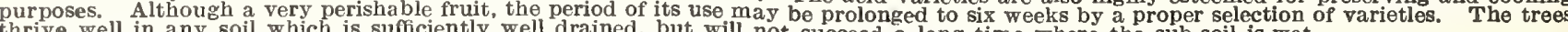
thrive well in any soil which is sufficiently well drained, but will not succeed a long time where the sub-soil is wet.

Our Cherry trees are all budded on Mahaleb stock, which makes a healthy tree, and does not sprout from the roots, which is a nuisance when common Morello stocks are used. Plant 18 feet each way; 135 trees to the acre.

\section{DUKE AND SOUR VARIETIES}

Cherry trees are very scarce. Place your orders early.

-year, extra selected trees

-year, $11 / 16$ and up, $41 / 2 \mathrm{ft}$. and up.

2 -year, $11 / 16$ and up, $41 / 2 \mathrm{ft}$, and up.

-year, $9 / 16 \mathrm{ft}$

Each

$\$ 1.25$

$.00 \quad \$ 9.00$

$\begin{array}{ll}7.50 & 60.00\end{array}$

$\begin{array}{ll}7.00 & 60.00\end{array}$

1 -year, $2 \frac{1 / 2}{\mathrm{ft}}$.

\section{DUKE VARIETIES}

May Duke.-Medlum, dark red, melting, rlch, julcy, excellent. A reliable early cherry, nearly sweet.

Late Duke.-Frult similar to May Duke, but later and not so sweet.

\section{SOUR VARIETIES}

Dyehouse.-A very early and sure bearer. Ripens a week before the Early Richmond.

RIchmond.-Medium size, light red; melting, juicy, sprightl acid flavor. Tree healthy and productive. One of the most popular early cherries.

Montmorency.-Large red cherry, ripening ten to fourteen days after Early Richmond. Trce a slow but stiff grower; very profitable bearer; valuable late sour cherry.

Morello.-Good size, very dark red when fully ripe, rich, acid, juicy, excellent for canning. Later than Montmorency.

\section{SWEET VARIETIES}

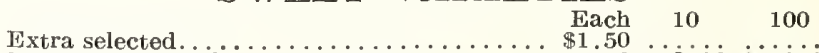

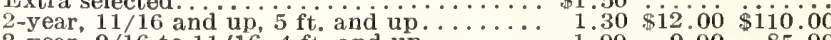

2 -year, $9 / 16$ to $11 / 16,4 \mathrm{ft}$. and up....... $1.00 \quad 9.00 \quad 85.00$

Bing_- Very large, à dark brown-almost black; flesh firm, sweet, rich and delicious. A noted western sort. Late.

Spanish (Sweet).-Large, pale yellow, firm, juicy and excellent. One of the best light colored cherries. Tree productive and a fine grower.

Schmldt.-Immense size. deep black, flesh dark, tender, very juicy, flne flavor; produc tive. July.

Tartarlan (Black).-Very large, black, juicy, rich. End of June.

Wood.-Large, light red, juicy, rich, delicious. June.

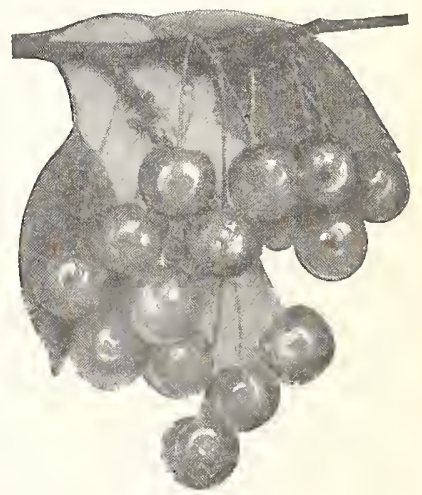

Montmorency 

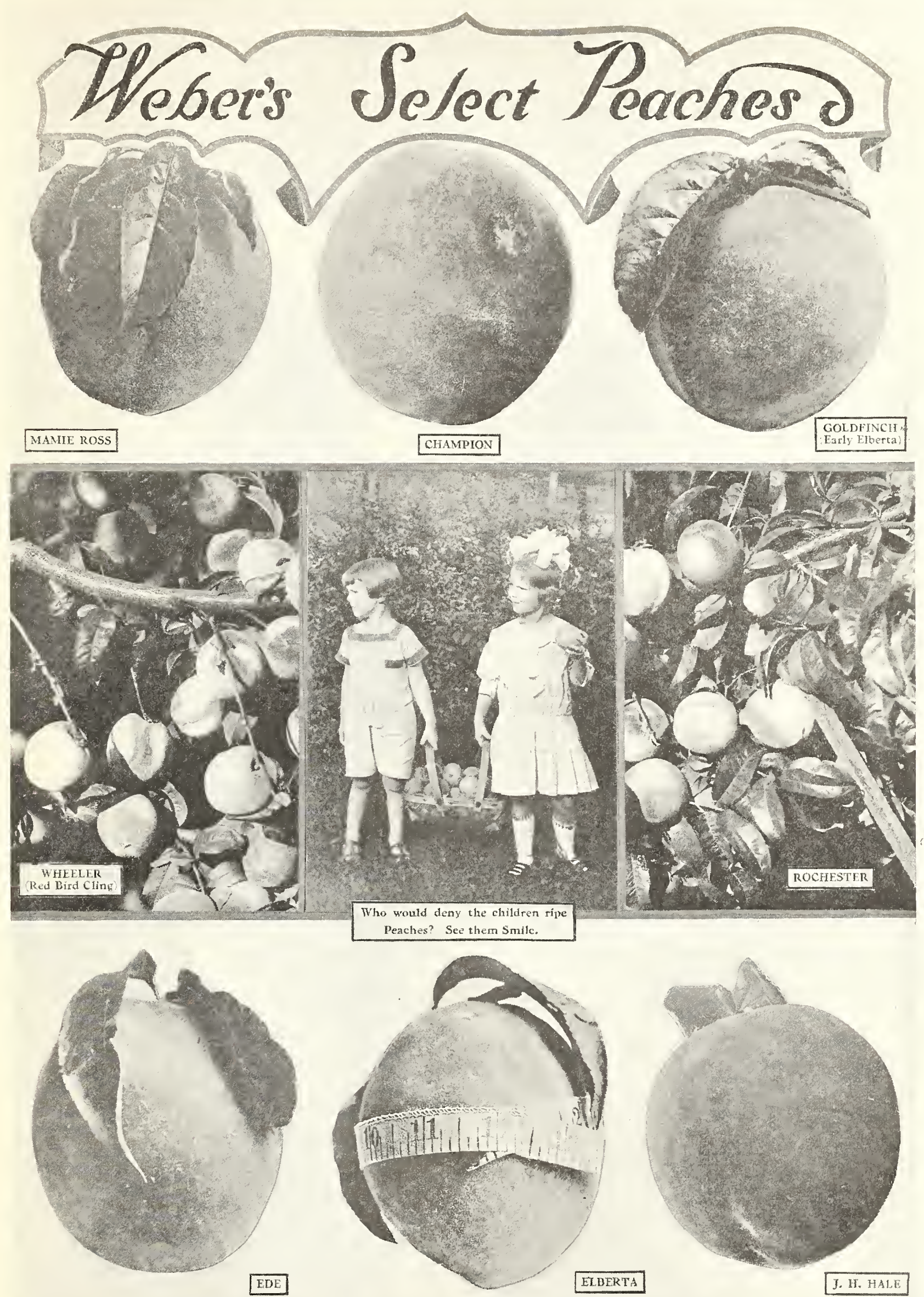


\section{Pear}

The cultivation of this noble fruit is extending as its vaiue is appreciated. The Pear, like most things highiy desirable and vaiuable.

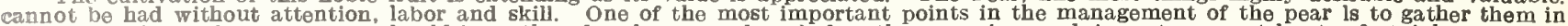

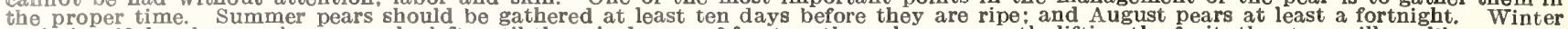

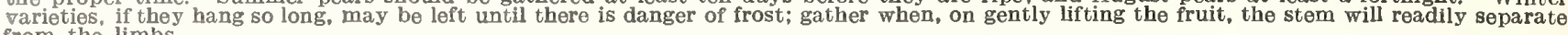
from the limbs.

Place in a dark room until fully matured. The Pear succeeds on most soils, but probably does better on rather sandy loam.

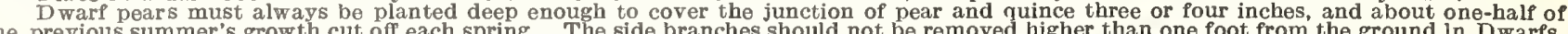

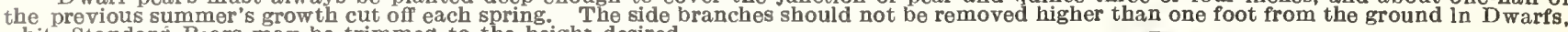
while Standard Pears may be trimmed to the height desired.

(The ietters " $U$ " and "s" appended to the descriptions of varieties indicate favorable growth, either as Dwarfs or Standards, or both.) Plant Standard varieties 20 to 25 feet apart; Dwarfs 10 to 12 feet apart.

2-year, $11 / 16$ and up, $5 \mathrm{ft}$. and up....... $\$ 1.20 \$ 11.00 \$ 100.00$ 2 -year, $9 / 16$ to $11 / 16,4 \mathrm{ft}$. and up....... $1.00 \quad 9.00 \quad 80.00$ Kîfifer and Garber only.

1-year, $9 / 16^{\prime \prime}, 31 / 2$ to $4 \mathrm{ft} \ldots \ldots \ldots \ldots \ldots \ldots \ldots . \$ \ldots 0.60 \quad \$ 5.00 \quad \$ 40.00$ 2-gear, $5 / 8$ and up, $31 / 2 \mathrm{ft}$, and up....

$$
1.009 .00
$$

\section{AUTUMN VARIETIES}

Bartlett (S).- One of the most popular pears: large, buttery and melting, with rich flavor. Tree a vigorous and erect grower; bears young and abundantly.

Clalrgeau (S).- Very large, yellow and red. Flesh yellowish. Keeps solid a long time after gathering. Free grower and abundant bearer.

Angouleme (Ducliesse) (D).-The largest of our good pears; succeeds on pear, but attains its highest perfection on quince, and is a

beautiful and vigorous tree. Most profitable for market. sprightly vinous flavor. Tree a vigorous grower and good bearer. Best on quince.

Garber (S). - One of the Japan Hybrids; the best and handsomest of its ciass. Earlier than Kieffer, larger and much better quality; free from blight; very hardy. Immensely productive; bears young: excellent for canning or preserving.

irowell (S).-Cone of the finest American pears. Large, hand-

e. sweet and melting; tree very vigorous, hardy and productive.

Klefer (S). -This is a seedling raised from the Chlnese Sand Pear crossed with the Bartlett. Skin rather rough. Color yellow. with red cheek in the sun. Flesh white, juicy, buttery and rlch. Tree a very strong. upright grower. Very proftable for market.

Seckel (S) - The standard of excellence in pears. Small but of highest flavor. Tree a strong, slow, erect grower; very hardy and bears abundantly.

Sheldon (S).-Fruit medium; coior greenish yellow, mostly covered with russet and a llttle brownish crimson in the sun. Juicy, trich, aromatic and sweet.

\section{WINTER VARIETIES}

Lawrence (S).-Slze medium to large; obovate; color a golden yellow; flesh melting, with a rich, aromatlc flavor. Tree a moderate grower and an abundant bearer.

\section{Plum}

The Plum tree wiil accommodate ltseif to most situations not absolutely wet, but produces its best fruit and most certain crops on heavy, clayey soil.

The great enemy of this, as weil as other smooth-skinned fruits, is the curculio, and as a knowledge of a practlcai remedy for this pest ls essentlal to the raislng of good crops, a description of the only method for its "destruction yet known is here given.

Shortly after the blossoms fall, and as soon as the presence of the insect is ascertained by his crescent-shaped mark upon the young

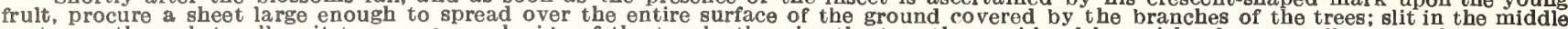

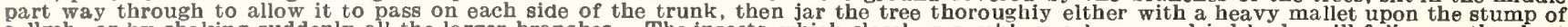

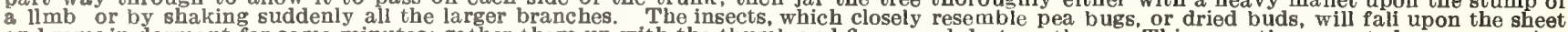

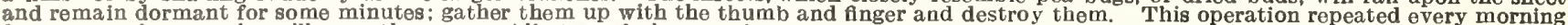

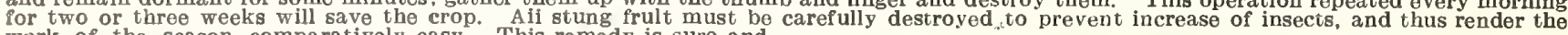
work of the season comparatively easy. This remedy is sure and iar more feasible than is sometimes supposed.

Plant 18 feet apart; 135 trees to the acre.

Our piums are budded on imported plum roots.

\begin{tabular}{|c|c|c|c|}
\hline $\begin{array}{l}11 / 16 \text { and } u p, 5 \mathrm{ft} \text {. and } u p \ldots \ldots \ldots \ldots \\
9 / 16 \text { to } 11 / 16,4 \mathrm{ft} \text {. and } u p \ldots \ldots \ldots \\
7 / 16 \text { to } 9 / 16,31 / 2 \text { to } 41 / 2 \mathrm{ft} \ldots \ldots \ldots \ldots\end{array}$ & $\begin{array}{r}\text { Each } \\
\$ 1.00 \\
.90 \\
.80\end{array}$ & $\begin{array}{l}10 \\
\$ 9.00 \\
8.00 \\
7.00\end{array}$ & $\begin{array}{l}100 \\
\$ 75.00 \\
70.00 \\
60.00\end{array}$ \\
\hline
\end{tabular}

\section{EUROPEAN VARIETIES}

Black Beauty - A cross between a Japan Plum and Damson Color almost black. Said to be one of the most productive and profitable varieties. Ripens in August. Damson (Common Blue). - A valuable market sort. It bears
Thousands of bushels are annuaily soid on our markets. It is the best plum for preserving. August and September.

Deck's Damson.-Larger than the common blue and an earlier bearer. Freestone.

German Prume.-Large, dark purple, sweet, good. One of the most popuiar and desirable for canning. September.

Lombard.-Medium, violet red, juicy, good, hardy and productive; the leading market variety. August.

Shropsh Ire.-An English variety of great merit for preserving. An abundant bearer and hardy.

Moore"s Arctlc.-Small, purpiish-black, juicy, sweet, lmmense bearer; one of the hardiest in bud and bloom. September.

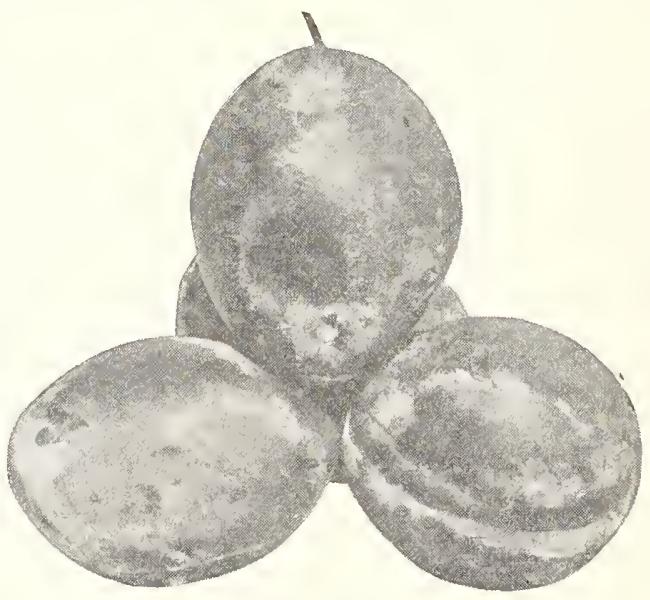

Lombard Plums 


\section{Plums-Continued}

\section{JAPAN OR ORIENTAL VARIETIES}

This class of plums and their hybrids are strong-growing trecs with light green foliage and attractive bloom, productive and usually commence bearing the third to fourth year after planting. They bloom very early, should be planted on north or west slopes and in sections not subject to late spring frosts.

$11 / 16$ and up, $5 \mathrm{ft}$. and up.

Each $10 \quad 100$

$\$ 1.00 \$ 9.00 \$ 75.00$ $\begin{array}{rrr}.90 & 8.00 & 70.00 \\ 80 & 7.00 & 60.00\end{array}$ $7 / 16$ to $9 / 16,3 \mathrm{ft}$, and up.

Botan.-Beautiful lemon-yellow ground, nearly overspread point like the Wild Goose; flesh orange yellow, melting, rich and aromatic. A ugust.

Burbank.-Large, nearly globular; clear cherry red. with a thin lilac bloom; flesh a deep yellow, very sweet and agreeable flavor. Hardy; one of the best for both garden and market planting. August.

Wickson.-A sturdy, upright grower, productive almost to a fault; fruit remarkably handsome, deep maroon: stone small a fault; fruit remarkably handsome, deep maroon; stone small; fine shipper.

\section{HANSEN HYBRIDS}

$11 / 16$ and up, $5 \mathrm{ft}$. and up............. Each $\$ 1.00 \quad \$ 9.00$

The varieties we are offering are all selected varieties that have proven profitable over a wide territory. We request our customer to try out some of these varieties. Trees do not grow large, hence can be planted quite close together, 15 feet being sufficient

The fruit is fine for culinary purposes and fine for eating fresh when fully ripe. Trees should be grown more in bush form for best results. We recommend the planting of several varieties close together as the blossoms fertilize each other. Try a few of these new plums, you will be more than pleased with them.

Waneta_-Good red color skin free from acidity and with delicious flavor. Two inches in diameter. Bear heavy and often have to have some picked from the tree to keep limbs from breaking. often bears second year when tree is well cultivated.

Sapa.-Very fine, perfectly hardy. Glossy, dark purple skin with rich dark purplish-red flesh

Opata.-Very beautiful when in bloom. Color of flesh green. flavor very pleasant. Ripens with us about July 10th, and will hang on the trees in good condition for about two weeks.

Hanska.-Bright red, heavy blue bloom, firm flesh, good quality. rich fragrance, bears early in abundance. When cooked has the flavor of an Apricot. Keeps well and has proven to be a good shipper.

Surprise.-Large bright red, flesh yellow, fine flavor. Ripens la te in August.

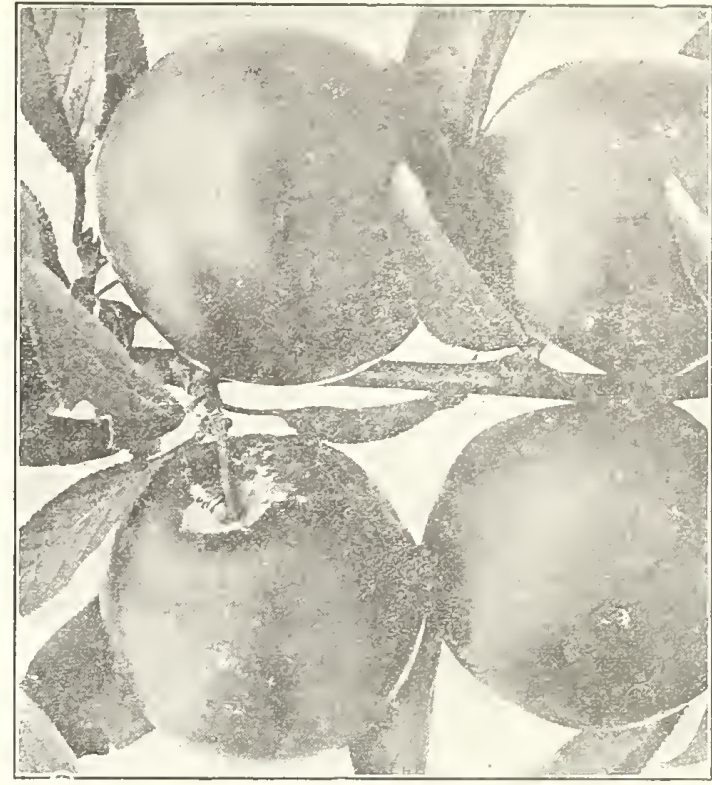

Black Beauty Plum

\section{CHICKASA W VARIETIES}

wild Goose.-Well known, large, deep red when ripe. Good quality: one of the best native plums: should be in every orchard July.

$11 / 16$ and up, $5 \mathrm{ft}$. and up..

Each $\quad 10 \quad 100$

$9 / 16$ to $11 / 16, \pm \mathrm{ft}$, and up.

$\$ 1.00 \$ 9.00 \$ 75.00$

$90 \quad 8.00 \quad 70.00$

$7 / 16$ to $9 / 16,3^{1 / 2} \mathrm{ft}$. and up.

\section{Miscellaneous Fruits, Nuts and Berries}

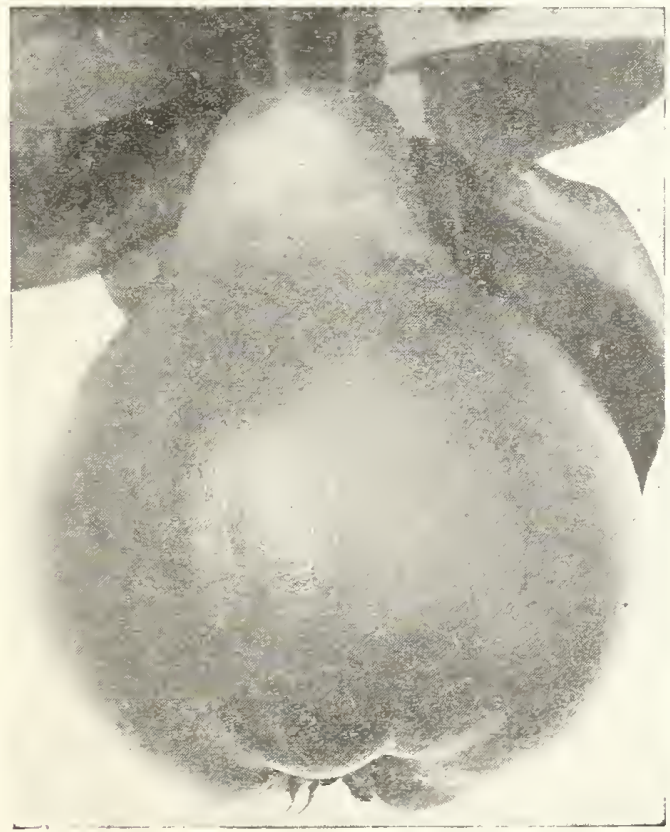

Champion Quince

\section{QUINCE}

The Quince is hardy and prolific, bearing its crops with great regularity. The fruit always commands a good market, and with most families is considered indispensable for canning and jelly.

The trees or bushes sliould have a good, rich soil, clean cultivation and an annual dressing of well rotted manure. Thinning out the twigs so as to keep the head open to the sun and air, and removing dead or decaying branches, is all the pruning that is required. Plant 10 feet apart each way, 435 trees to the acre.

Champlon.-Originated in Connecticut. The tree is a prolific and constant bearer: fruit averaging larger than the Orange, but not so high colored; more oval in shape. Quality equally as fine. and a good keeper.

a good keeper it large bright yellow color: a good bearer. The standard variety in quince.

$5 / 8$ and $\mathrm{up}, 4 \mathrm{ft}$, and up

\section{APRICOT}

There is no fruit more delicious or beautiful than the Apricot, and its ripening between cherries and peaches renders it especially
valuabie. Its chief enemy is the curculio, which can be kept in check by the method suggested for plums. Plant the same as plums.

Early Golden-Small size: color pale orange yellow: juicy and sweet; exquisite flavor.

Royal.- Large, yellow, juicy, rich and delicious; a very fine variety.

$9 / 16$ to $11 / 16,4 \mathrm{ft}$, and up.

Each 10

\section{MULBERRIES-MORUS}

American.-Equal to Downing in fruit, but much hardier rigorous grower, very productive; the hest variety for fruit; ripe from middle June to middle September.

5 to $6 \mathrm{ft}$., each........................... \$1 2

Russlan.- Very hardy, vigorous grower; valuable for feeding sllk worms, also relished by birds.

5 to $6 \mathrm{ft}$. Each 10 Downing. - Very large, black, handsome, sweet, rich and excellent.

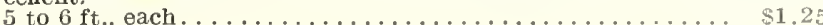




\section{Raspberries}

Will do well on any soil that will produce a good corn crop. Land should be thoroughly prepared and well enriched; ground bone is one of the best fertilizers. Keep well cultivated and free from weeds and suckers. As soon as they have done bearing, cut out the old wood to give vigor to the young canes. Spring is the in rows, 2,420 plants to the acre.

Write us for prices on larger quantities.

If wanted by parcel post add $10 \mathrm{c}$ to the 10 price, $15 \mathrm{c}$ to the 25 price, 50c to the 100 price to cover cost of postage and
extra packing. 1,000 lots should be sent by express.

\section{RED SORTS}

Cuthbert.-A remarkably strong, hardy variety; berries very large, rich crimson, very handsome, sweet, rich and luscious; highly tlavored.

Each. 10 cents; per $25, \$ 1.75$ : per $100, \$ 5.00$; per $1,000, \$ 35.00$.

King.-Said by many to be the best early red raspberry. Plant a strong grower, hardy and productive. Berry firm; good shipper; large size; color bright scarlet

Each. 10 cents: per 25, \$1.75; per 100, \$5.00: per 1,000, $\$ 35.00$.

St. RegIs. - This variety has proven its worth again during the season of 1917, producing fine crops of fruit. Begins to ripen with the earliest and continues to bear on young wood until Ocwith the earliest and continues to bear on young wood until October. Berries bright crimson, large size, rich sugary raspberry flavor. the first or main crop, equalling any red variety known. Canes the first or main crop, equalling any red variety known. Canes
stocky. of strong growth, with abundant dark green leathery foliage. Stocky, of strong growth, with abundant dark green leathery
Each, 10 cents; pes $25 . \$ 1.75$; per $100, \$ 5.00$; per $1,000, \$ 35.00$

\section{PURPEE SORTS}

Columbian.- An improvement on Shaffer's, which it resembles, but the berry is much firmer, adheres to the bush much longer and retains its shape better, both on the market and for canning. Bush a stronger grower, attaining a very large slze, One
of the hardiest and wonderfully prolific. Unexcelled for productiveuess, and stands at the head for canning. making jam, etc.

Each, 15 cents; per $25, \$ 2.00$; per $100, \$ 6.00$; per $1,000, \$ 50.00$.

\section{BLACK SORTS}

Cumberland.-The largest of all black caps. A healthy, vigorous grower, throwing up stout, stocky, well-branched canes, that produce immense crops of magnificent berries. Fruit very large. firm; quality about the same as Gregg: keeps and ships well as any of the blacks. The most profitable market variety.

Tips.

$\begin{array}{llll}\text { Each } & 25 & 100 & 1,000\end{array}$

Kansas.-A strong, vigorous grower, standing extremes of drought and cold and bearing immense crops. Early, berrles size of Gregg, of better color; jet black and almost free from bloom; firm, of best quality; pr.

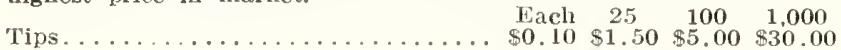

Plum Farmer--A few days later than Kansas: matures its crop in a very short period, making it one of the most profitable similar to Gregg. Large berries.

Tips

Each $25 \quad 100 \quad 1,000$

\section{Gooseberries}

Can not be shipped to states west of Iowa, Missouri and Arkansas, or to Minnesota, account embargo.

This fruit requires the same cultivation as the currant. The surest method to prevent mildew is to plant thickly in the rows and mulch deeply six or more inches with straw, tan bark, coal ashes, etc. Plantations thus treated have borne large crops for twenty years. The mulch retains moisture in the driest weather: the fow weeds that push up are easily pulled, and the fruit is large the fow weeds that push up are easily pulled, and the fruit is large is underdrained, or it is worse than useless, Good cultivating is better than half mulching. Put it on thick. In a dry season the extra a mount of fruit will double pay for the material used not to extra amount of fruit will double pay for the material used, not to speak of the saving of labor and cleanliness of the fruit. The price is remunerative and the demandis yearly increasing. The American bushes as soon as the leaves appear in the spring, and several times during the summer, with potassium sulphide (liver of sulphur), one ounce to four gallons of water. in the rows-2,904 plants to the acre. Write for prices on larger quantities than quoted.

If wanted by parcel post add $5 \mathrm{c}$ per plant to the price quoted to cover postage and extra packing.

Downing.-Size medium to large, oval, greenish white; plants vigorous, upright, very productive; never mildews.

2 -year, No. 1...... $\begin{array}{lcc}\text { Each } & 10 & 100 \\ \$ 0.25 & \$ 2.00 & \$ 15.00\end{array}$

Houghton.-A vigorous grower; very productive; not subject to mildew. Flesh tender and very good. Red when ripe.

2-year, No. 1 ..

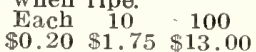

\section{Curraints}

Cannot be shipped to states west of Iowa, Missouri and Arkansas, or to Minnesota, account enibargo.

Currants should be planted in good, very fertile soil, with hiberal manuring, and the tops should be cut back nearly to the crown, allowing only three or four canes to grow the first year. Prune more or less every year to get rid of old wood and keep the one ounce to three gallons of water, and applied with a sprinkling one ounce to three gallons of water, and applied with a sprinkling
can. Be sure to use the remedy as soon as, or before, the worms can. Be sure to use the remedy as soon
appear. Plant the same as Gooseberries.

Write for prices on larger quantities than quoted.

If wanted by parcell post, add 5 cents per piant co cover postage and extra packing.

Fay.-The best currant yet introduced; berries are large, uniform in size, with long stems, good flavor, and is very productive and easy to pick.

2-year, No. 1

$\begin{array}{ccc}\text { Each } & 10 & 100 \\ \$ 0.20 & \$ 1.50 & \$ 13.00\end{array}$

London.- Largely planted in Michigan and regarded there as one of the best market varieties. Plant is extremely vigorous, with perfect foliage, which it retains through the season; an enormou
cropper; ripens with Victoria: is large in bunch and berry. Cictoria: is large in bunch and berry. 100 $\begin{array}{lll}\text { Each } & 10 & 100 \\ \$ 0.20 & \$ 1.50 & \$ 13.00\end{array}$

Perfection.- The color is a beautiful bright red. Size as large or larger than Fay, the clusters averaging longer. The Perfection has a long stem from the point of attachment to the bush to the first berry, making it easy to pick without crushing any of the berries. It is a great bearer, and on account of its great productiveness the plants should be kept well cultivated and fertilized, as should all heavy bearers. The Perfection ripens about the same time as the Received the "Barry Medal" in July, 1901, the highest award given to any new fruit at the Pan-American Exposition. The Gold Medal was awarded this currant at the Louisiana Purchase Exposition in 1904 . Each $10 \quad 100$
$\$ 0.30 \$ 2.50 \quad \$ 20.00$ 2-year, No. 1

Wulder.-Introducer says: "Wilder will make twice as much wood as will Fay's Prolific, while setting as large fruit wlth double and triple the quantity: combines more good qualities than any red currant he has ever fruited." It is large, very productive, sweet and hangs a long time on the bushes in fine condition after fully ripe.

2-year, No. 1 Each $10 \quad 100$

White Grape-_Large, yellowish white; sweet or very mild acid; excellent quality and valuable for table use. Productlve.

2-year, No. 1 $\begin{array}{llll}\text { Each } & 10 & 100\end{array}$

Cherry.-Very popular in market and brings several cents more per quart than any other old variety.

2-year. No, 1 , $\begin{array}{ccc}\text { Each } & 10 & 100 \\ \$ 0.20 & \$ 1.50 & \$ 13.00\end{array}$

\section{Blackberries}

Many kinds of blackberries will succeed, not only on good fruit and, but even on the most sandy, porous soil. They require the same treatment as recommended for raspberries, culture should be planted in rows seven feet apart and three feet distant in the rows; in garden culture, plant rows five feet apart and three feet distant in the rows. The pruning should be governed in summer when three feet high, causing them to throw out laterals.

When planting 7 by 3 feet it takes 2,078 plants for an acre.

When planting 5 by 3 feet apart it takes 2,904 plants for an acre. are free from disease.

If wanted by parcel post, addil 10e to the $10 \mathrm{price}, 15 \mathrm{c}$ to the 25 price, 50c to the 100 price, to cover postage and extra packing. 1,000 lots shouid be sent by express.

Blowers.-Originated in Chautauqua County. New York. Claimed to be the hardiest, most productive and the finest quality of all the blackberries. Large size, jet black, good shipper. We believe this variety has special merit.

Per 10, $\$ 1.10$; per $25, \$ 1.85$; per $100, \$ 6.00 ;$ per $1,000, \$ 50.03$. cultivation: a compact, dwarf grower; fruit medium size and fine quality: an enormous bearer

Per $10,75 c ;$ per $25, \$ 1.50$; per $100, \$ 4.75$; per $1,000, \$ 33.00$

Eld orado. - Very vigorous and hardy, enduring the winters of the far Northwest without injury, and their yield is enormous. The berries are large, jet black, borne in clusters, and ripen well together; they are very sweet, melting and pleasing to the taste: have no hard core

Per 10, $\$ 1.00$; per $25, \$ 1.75$; per $100, \$ 5.50$; per $1.000, \$ 45.00$.

\section{Dewberries}

Lucretia.-One of the low-growing, trailing blackberries; in size and quality it equals any of the tali-growing sorts. Perfectly hardy, healthy and remarkably productive, with large showy flowers. The fruit, which ripens early, is often one and one-half inches long by one inch in diameter: soft, sweet and luscious throughout, with mulched to keep berries from the ground.

If wamted by parcel post add $10 \mathrm{c}$ to the 10 price, 15c to

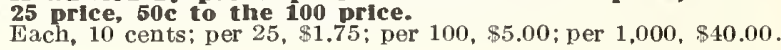




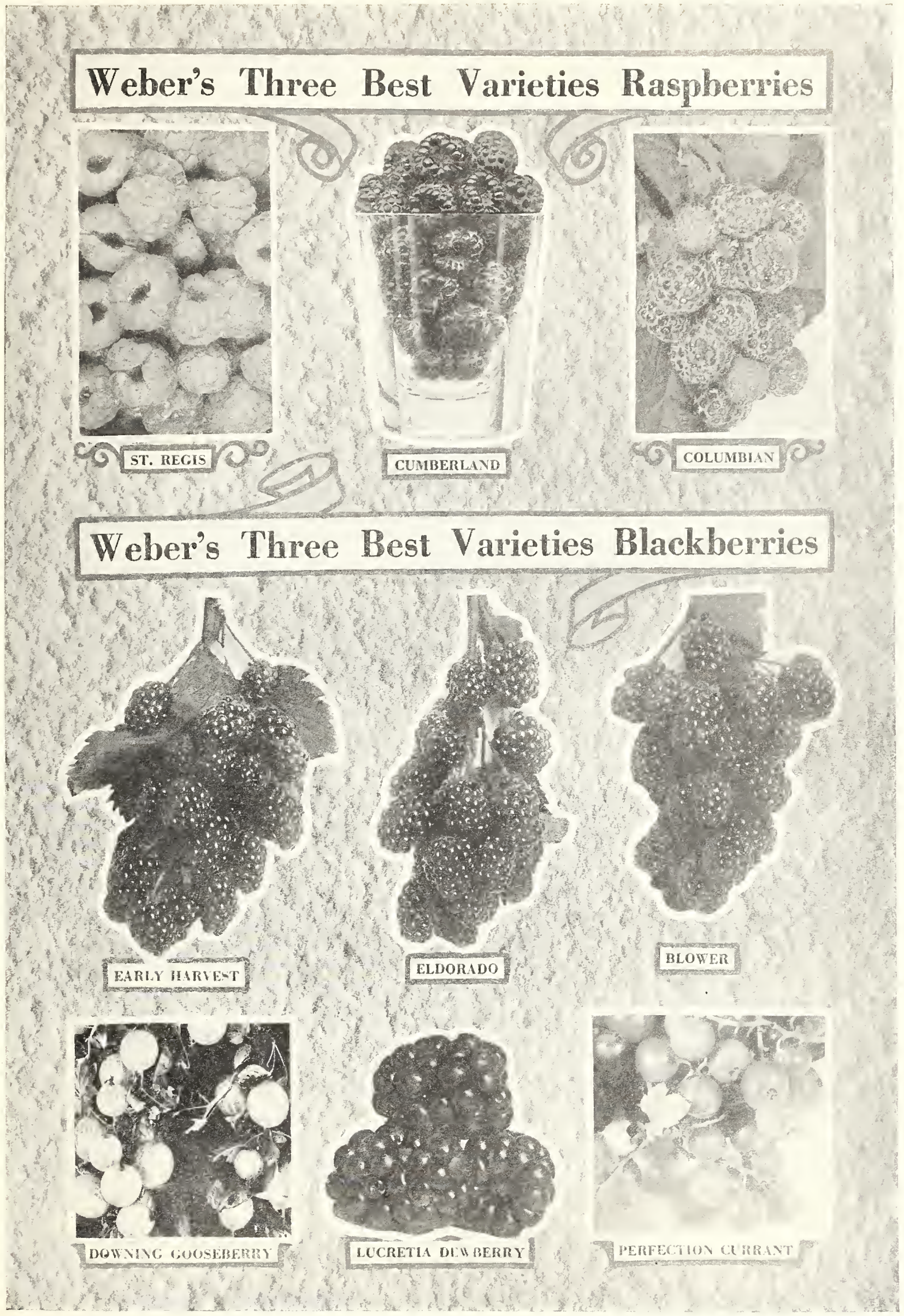




\section{Grapes}

There is scarcely a yard so small, either in country or city, that room for one to a dozen or more grape vines cannot be found. They do admirably traincd up to the side of any building, or along the garden fence, occupying but little room and furnishing an abundance of the healthiest fruit. Make the soil mellow and plant the vines somewhat dceper than they stood in the nursery. Plant about eight feet apart, along the fence or building. For vineyard purposes make rows eight feet apart, six feet in rows.

To plant an acre, 6 by 8 feet, requires 908 plants. Write us for prices on larger quantities.

If wanted hy parcel post add $2 \mathrm{c}$ per plant to the prices quoted up to 100 lots to cover postage and extra packing. 1,000 lots should be sent by Express or Freight.

Campbell Eariy.-A fine healthy and early variety, profuse bearer. Ripens with the Moore's Early but keeps on the vine or in the house for weeks.

2-year, No. 1

Eacli $10 \quad 100$

Concord.-The old stand-by. A large, purplish black grape vlne remarkably hardy, vigorous and productive. Very popular best market sort. 9-year, No. 1.......... \$0.20 \$1.75\$15.00\$12000 1-year. No. 1............ $.15 \quad 1.25 \quad 10.00 \quad 85.00$

Moore.-Bunch medium, berry large, round, with heavy bloom: vlne exceedingly hardy, entirely exempt from mildew or disease. its earliness makes it desirable for an early market. Two weeks earlier than Concord.

2-yeal', No. 1 . . $\begin{array}{cccc}\text { Each } & 10 & 100 & 1000 \\ \$ 0.25 & \$ 2.25 & \$ 20.00 & \$ 170.00\end{array}$

Worden.-A splendid large grape, of the Concord type, but earlier, and in every way as healthy. Quality good to best.

2-year, No. 1 Each $10 \quad 100 \quad 1000$

\section{RED OR AMBER SORTS}

Agawam (Rogers' No. 15).-Berries very large, with thick skin; pulp soft, sweet and sprightly; very vigorous; ripens early.

$\begin{array}{rlll}\text { Each } & 10 & 100 \\ \$ 0.30 & \$ 2.50 & \$ 22.00\end{array}$

Brighton.-Bunch läge, well formed; berries above nedium to large, round; excellent flavor and quality; one of the earliest in ripenine, round, excellent flavor and quality, one th 10 2-year, No. 1..................... \$ \$0.50 \$4.50\$40.00

Catawba.-Bunches of good size, rather loose; berries large, round; when fully ripe of a dark copper color, with a sweet, rich round; when fully ripe of a dark copper color, with a sweet, rich
musky flavor. musky flavor.

Delaware.-Bunches small, compact, shouldered; berries rather small, round; skin thin, light red; flesh very juicy, without any hard pulp, with an exceedingly swcet, spicy and delicious flavor.

Each $10 \quad 100$

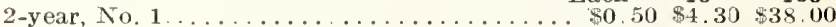

\section{WHITE SORTS}

Diamond.-Grape from Concord seed, fertilized with Iona. In vigor of growth, color and texture of foliage and hardiness of vine it partakes of the nature of its parent Concord, while in quality the fruit is equal to many of the best tender sorts, and ripens two weeks earlier than the Concord.

- No, $1, \ldots \ldots \ldots \ldots \ldots \ldots \ldots \ldots$ $\$ 0.30 \$ 2.50 \quad \$ 22.00$

Niagara.-Vine remarkably hardy; strong grower; bunches very large and compact, sometimes shouldered; berries large; light greenish white semi-transparent. shightly ambered in the sun skin thin but tough and does not crack: quality good: very little pulp; melting and sweet to the center

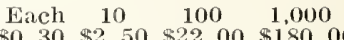

\section{Strawberries}

As we have not grown Strawberry plants for the past few years and have accommodated our patrons by securing them from reliable

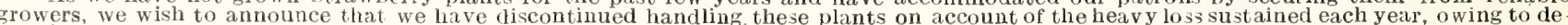

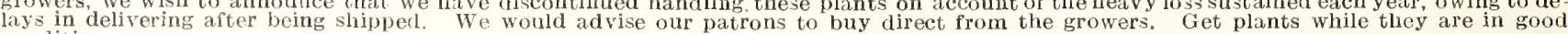
condition.

\section{Map Showing Location of Our Nurseries}

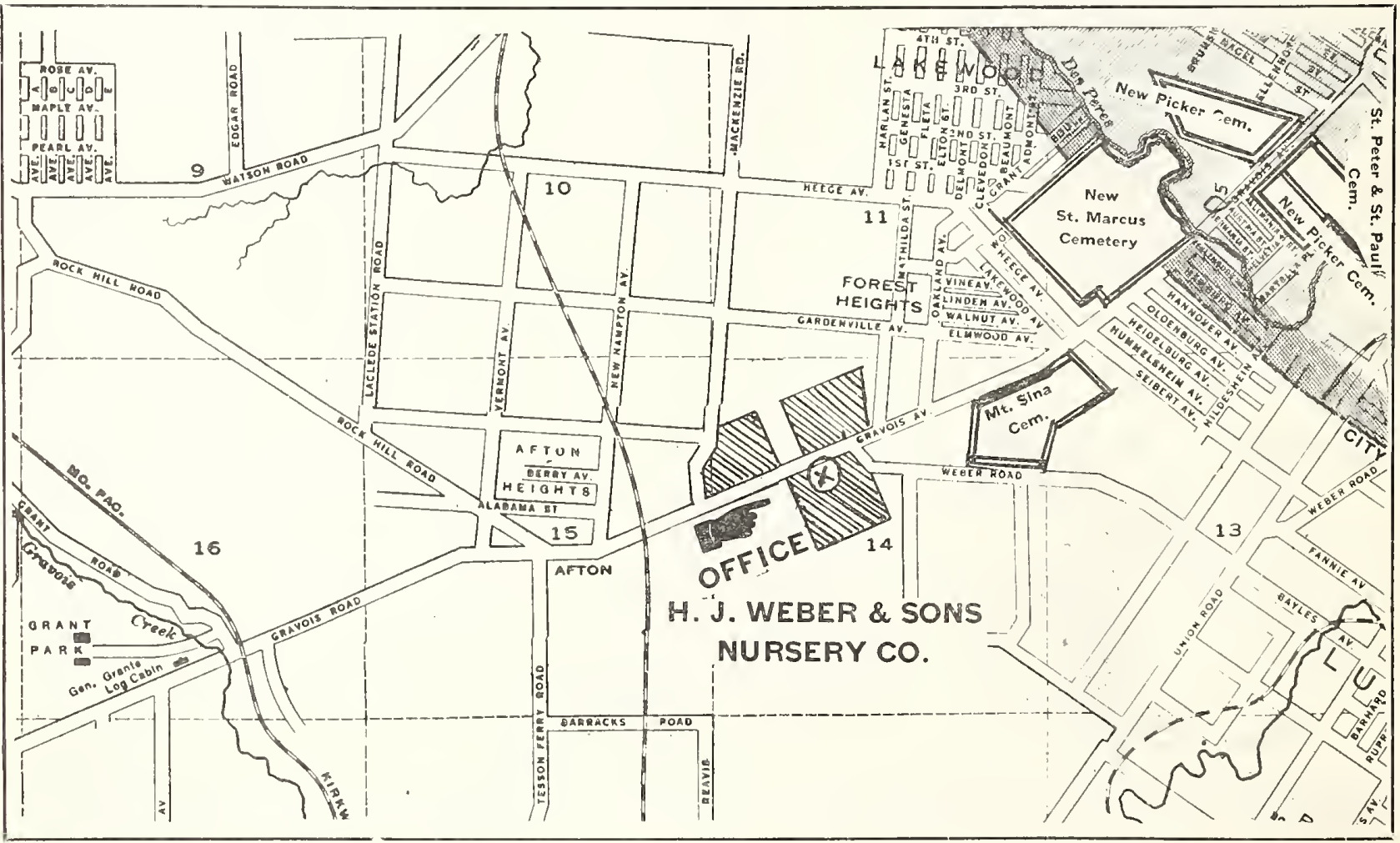




\section{Weber's Grapes}

\section{Weber's Red, White and Blue Collection No. 1}

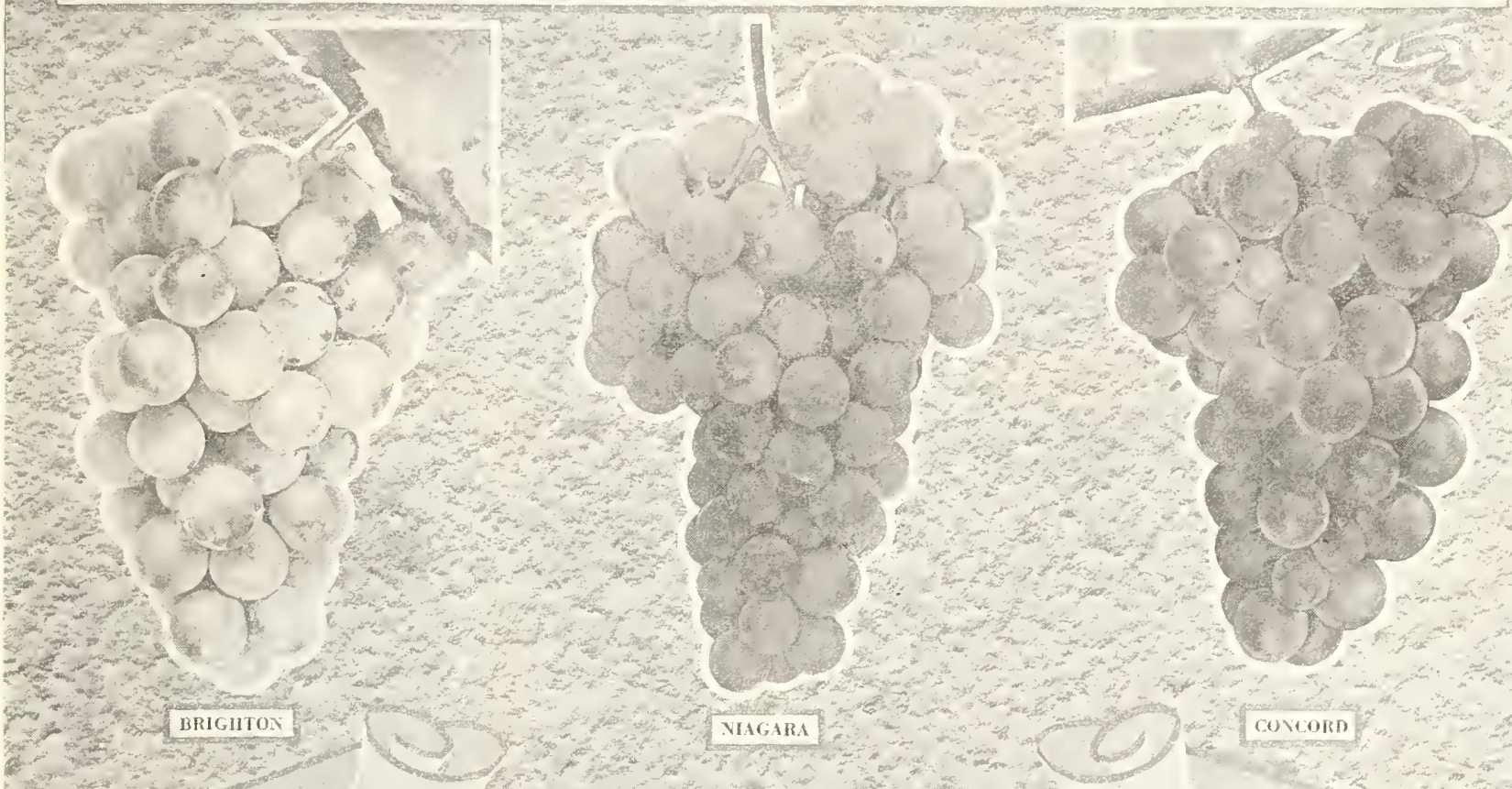

\section{Weber's Red, White and Blue Collection No. 2}
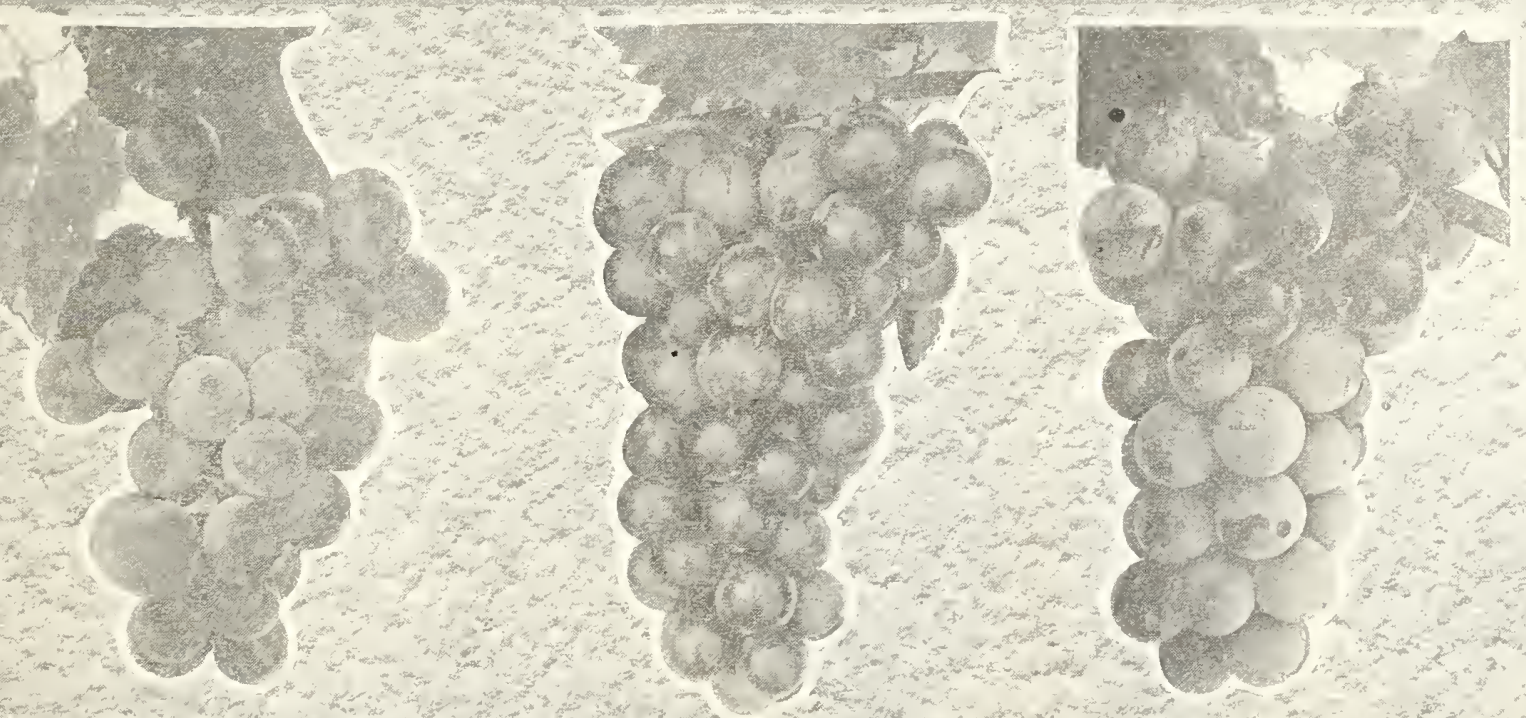

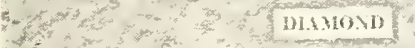

MOORES EARII

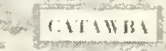

Collection No. 1-1 Each, 3 Above Named Varieties, Postpaid 


\section{NUT TREES}

The growing demand for nuts and the immense quantities Imported annually is giving an impetus to the planting of nutbearing trees in America. Many farms contain land that would be far better planted to nut trees than in anything else, and would pay better than farm crops, besides annually growing more valuable as timber. In planting ordinary nut trees we would advise planting the smaller size stock-say one or two year seedlings- for best results.

Chestnut (Japan or Giant), -A dwarf grower. Very distinct from other kinds, the leaf being long and narrow, of a dark green color. A fne ornamental tree in any situation. Commences bearing color. A ne ornamental tree in any situation. Contronces bearing very young; two-year trees in nursery row frequently produce nuts.
Nuts are of good size. The productiveness, early bearing and

enormous size render these of great value.

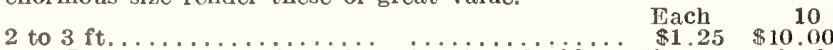

Chestnut (American sweet). - $\mathrm{A}$ " valuabie native tree, both useful and ornamental; timber very durable and possesses a fine grain for oil finish. Nuts sweet and of delicate favor, and a valuable article of commerce. No farm should be without a grove of these where the soil is adapted to their growth.

4 to $5 \mathrm{ft}$

Fach $\quad 10$

Walnut (Ämerican Black). - The large, oily nuts are borne in heavy crops. They are much relished and always bring a fair prlce in market. The tree grows quite fast; its wood is exceedingly valuable.

4 to $5 \mathrm{ft}$.

5 to $6 \mathrm{ft}$.

Each 10

$1.10 \$ 10.00$

$1.10 \quad 10.00$

6 to $7 \mathrm{ft}$ Wainu (Japan sieboldi).-From the mountains of Northern Japan. Leaves of Immense size, a charming shade of green. Nuts resemble pecans and are produced in abundance, grow in clusters of ten to fifteen. 3 to $4 \mathrm{ft}$.

3 to $4 \mathrm{ft}$.

5 to $6 \mathrm{ft}$

$\begin{array}{ll}\text { Each } & 10 \\ \$ 1.00 & \$ 9.00\end{array}$

$\begin{array}{ll}1.30 & 12.00 \\ 1.50 & 14.00\end{array}$

IIARDY GRAFTED ENGLISII WALNUT TREES

These are not the tender varieties grown in the South. but are the hardy variety grown in New York State, Pennsylvania and Ohio.

Mayette. - Probably the largest, thin shell, smooth and attractive.

Franquette.-Tree hardy and reliable, nuts medlum large, shell fairly thin, cracks easily.

$\begin{array}{cc}\text { Each } & 10 \\ \$ 1.50 & \$ 13.00\end{array}$ 3 to $4 \mathrm{ft}$.

ECAN TREES

HARDY GRAFTED NORTIIERN-GROWN PECAN TREES

We have arranged with ono of the best known growers of Grafted 1926 Delivery. The fo!lowing varieties are recommended for this
section:

Indiana.-From Innox County, Indiana. One of the largest and best. Nut is thin shelled, full meated and good quality. Heavy cropper.

Greenriver. - Originated in Henderson County, Kentucky. Nut medium size, shell thin, kernel full and plump and of the best quality.

Butterlck.-From Grayville, Illinois. One of the oldest Pecan trees of the Indiana group. A real paper-shcll of exccllent quality. Nuts are large and long, with thin shell and a very large and plump kernel. One of the best for general planting.

Niblack.- Originated in Knox county, Ind. Nut medium to plump. Of the best quality.

Grafted or Budded Trees, 3 to 4 feet.......... $\$ 2.75 \$ 25.00$

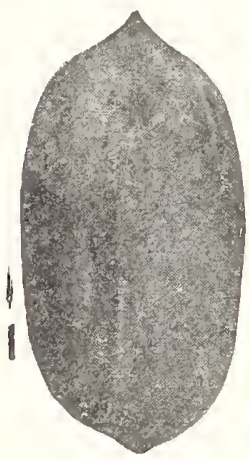

Indiana

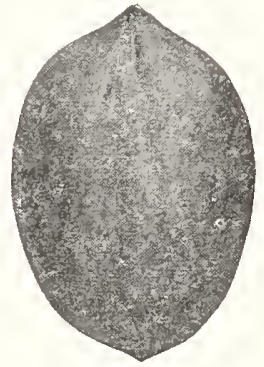

Greenriver

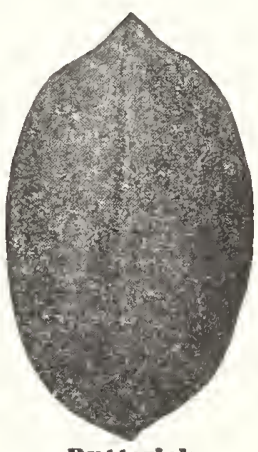

Bntterick
NO FARM-Whether Grain, Dairy or Truck, is complete without a family orchard, consisting of selected fruits for home consumption, canning, etc.
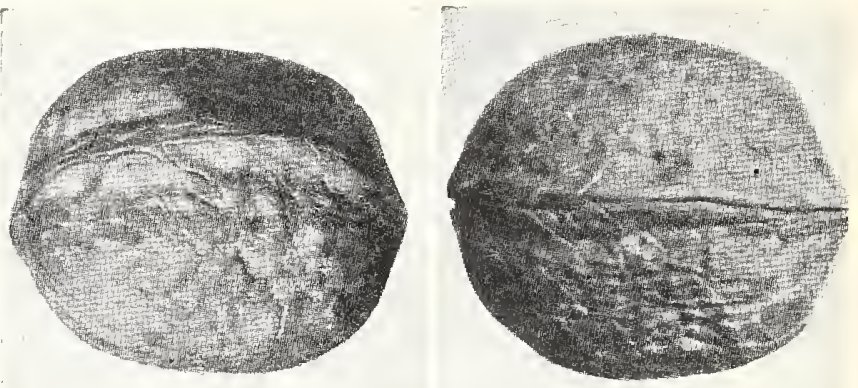

English Walnut

\section{PERSIMMON (AMERICAN)}

The Persimmon makes a very handsome ornamental tree, and is hardy in this sectlon. The fruit, although pungent when green becomes sweet and palatable if allowed to remain on the tree exposed to the eariy frosts.

4 to $5 \mathrm{ft}$., each ............................. \$1.00

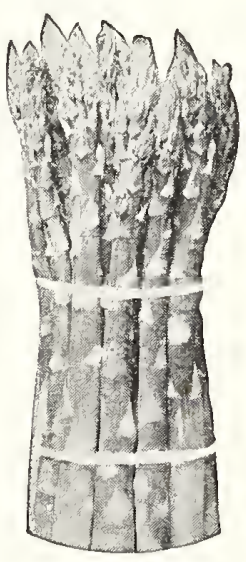

Asparagus

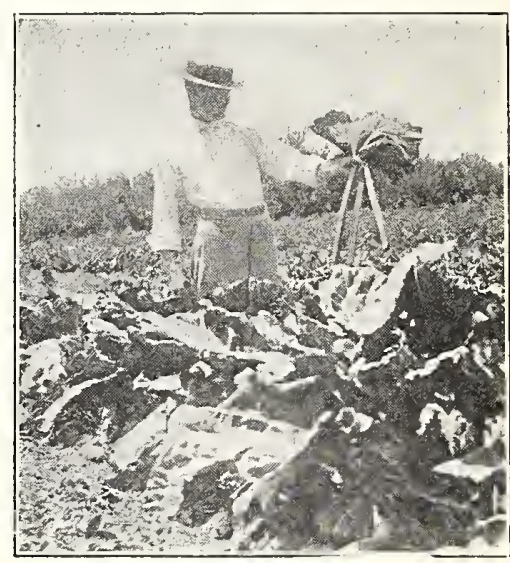

Rhubarb

\section{Asparagus}

For garden culture dlg a trench 18 lnches wide and 12 lnches deep, trenches 4 feet a part: fill in some well rotted manure in bottom of trench: then cover same with top soil about 2 inches. Plant on top of that, 18 inches apart in the row, and only cover the plant top of that, 18 inches apart in the row, and only cover the plant about 2 inches with good, fine soil, flling in the balance by degrees early in spring after loosening the beds on top by forking them over. Write us for prices on larger quantities.

If wanted by parcel post, add 10c for 25 plants: $30 \mathrm{c}$ for 100 plants: 1,000 Iots should be sent by Express or Frelght. 2 -year, No. $1 \ldots \ldots \ldots \ldots \ldots \ldots \ldots \ldots \ldots \ldots \ldots . \$ \ldots 1.00 \quad \$ 2.00 \quad \$ 15.00$ 2-year, No. 2 Argenteut. - A fine and profitable variety; stocks mammoth in size: attractive color, sweet and tender; an immense yielder, and early

Conover.-A mammoth variety of vigorous growth; an old and well-tried sort; very popular

Palmetto.- Of Southern origin. It is earlier, a better yielder more even and regular in its growth, and in quality equal to that old favorite, Conover's Colossal.

Washington (New) - A new rust-rcsistant pedigreed Asparagus. 2 year, No. 1.................... \$1.25 $\$ 3.00 \quad \$ 2000$

\section{Rhubarb or Pie Plant}

This deserves to be ranked among the best early fruits of the garden. It affords the earliest material for pies and tarts, continues long in use and is valuable for canning. Make the bed very rich and deep. Plant in rows four feet apart and the plants threo feet distant. Set the roots so that the crowns are about an inch below the surface.

Linnaeus.-Large, early, tender and fine; the very best of all.

If wanted by parcel post. add $10 \mathrm{c}$ per plant to cover postage and extra packling.

Large clumps. $\begin{array}{lll}\text { Each } & 10 & 100 \\ \$ 0.25 & \$ 2.00 & \$ 15.00\end{array}$

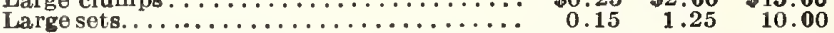

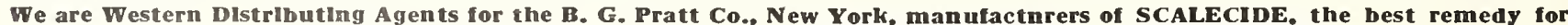
Scale Insects. Apple Canker. Collar Rot and Blight Canker. Send for FREE Literature. 


\section{Ornamental Department}

\section{Brief Suggestions to Planters}

A tew dollars spent for trees and shrubs to Improve your property will increase Its value far more than the expenditnre. What to Plant.-Impressed with the importance of planting only the most hardy ornamentai trees and shrubs, and in order that our patrons may be spared much disappointment and expense, we have, as far as possible, omitted from our catalogue anything that is lable to suffer from severe cold. We have with great pains secure to An examination of this cata of this class as complete as possible. of stock is offered, enabling the planter, by a judicious use of the same, to accomplish any desired result with perfectly hardy trees, shrubs and plants. For convenience we have grouped the trees under the following heads: Deciduous Trees, Weeping Deciduous Trees, Ornamental shrubs, Vines and Climbers, Hedge Plants, Roses (Hybrid Perpetual, Everblooming, Climbing, Trailing, etc.) Evergreens. Perennials and Greenhouse Plants.

For Parks and Extensive Grounds. - No diffeulty can be experienced by anyone in making selections for this purpose. But we cannot impress too strongly tbe importance and value of flowering slrubs for effective masses and groups. There are many who imagine that Rhododendrons and Azalea are indispensable. This is a great error. In this latitude both Rhododendrons and Azaleas
require prepared soil and protection, while hardy shrubs like the Weigela, Deutzia, Spirea, Hardy Hydrangea, Japan Quince, DoubleFlowering Almonds. Lilac, Snowball, Althea, Paeony, Phlox and Japan Anemone, when planted in masses, produce a magniflcent effect, need no protection and demand littie skilif or care ln their management. What grand masses of bloom can be had throughout the season by the proper use of the various famflies. Then the purple and variegated-leaved trees and shrubs may aiso be planted in such a manner as to afford a rich and striking contrast, Groups of flowering trees form superb objects at the blossoming season. and it is strange that planters do not employ them more.

Highly effective groups can be formed of trees and shrubs possessing bright colored bark in winter.

For Lawns and Small Places. - Whatever specimens are pianted should be of the flnest species, of moderate size, of graceful hablt of growth and handsome foliage, A penduious tree or one With variegated foliage may be occasionally introduced and will add to the beauty of the grounds. Depend mainly upon dwarf shrubs for small places, and in selecting, aim at securing a succession of bloom. Dwarf evergreens are very useful, and in small grounds factory results. A proper selection will afford as much bioom as ordinary bedding plants, and at half the trouble and expense.

When to Plant.-Declduous Trees, Shrubs and Vines can be piantcd either ln Spring or Fall. Spring is the best time for Ever15 th to October 20 th.

How to Plant.-Preparation of the Roots: Cut off smoothly all bruised or broken roots up to the sound wood; this prevents their decaying and hastens the emission of new roots and fibers.
Preparation of the TOD.-This consists in cutting back the top and side branches in such a way as to correspona with the more ss mutilated roots, as follows:

Trees with branchlng heads should have the small branches cut clean out, and the larger ones, intended for the framework of the tree, cut back till within two or thrce buds of their base. In cases where there is an abundant root, and small top or few branches, the pruning need be very light; but where the roots are smail and the top heavy, severe pruning will be necessary. These remarks are applicable to all Deciduous Trees and Shrubs. Evergreens seldom require pruning, but Arborvitae and other Evergreens planted in
hedge rows may be advantageousiy shorn immediately after planting.

Prunlng, as practiced by some people, has the effect to render trees and shrubs unnatural and inelegant. We refer to the custom of shearing trees, particularly Evergreens, into cones, pyrhas a habit of growth peculiar to itseif, and this very peculiarity is one of its beauties. If we prune all trees lnto regular sbapes we destroy their ldentity. The pruning knife, therelore, should be used to assist nature, and bandled with judgment and care; to top off straggling branches, to thln the head of a tree which sometimes comes necessary to prune severely to keep a tree from attalning too comes neces

Shearing may be practiced on hedges, but never on trees or shrubs.

Pruning Shrubs.-Many persons train and shear them into regular shapes, imagining that regular outline adds to their effect and beauty. While symmetry and regularity of outline are to be admlred in a shrub, this quailty should never be gained at the expense of health and natural grace. Each shrub has lts peculiarities of habit and foliage, and we should alm to preserve them as far as possible. Judicious pruning to secure health and vigor ls necessary, but trimming all klnds of sbrubs into any one form shows a lack of appreciation for natural beauty, to say the least. Weigelas. a lack of appreciation for natural beauty, to say tbe least. Weigelas.
Spireas, Deutzias, Forsythia and Mock Orange flower on the wood of the previous season's growth, hence these shrubs should not be pruned the previous season's growth, hence these shrubs should not be pruned when the old wood should be shortened or cut out, thus promoting the thew th of the young wood which is to flower the following season. Altbeas and Honeysuckles may be trimmed during the winter or early in the spring, but the branches should only be reduced enough to keep them in good shape. The old growti should be occasionally thinned out and the suckers and root sprouts removed when they appear. The best time, however, for pruning all shrubs is when they have done flowering.

The Hydrangea Paniculata Grandiflora should be severely cut back and thinned early in spring.

Pruning Evergreens.- Use the knife occasionally to thicken the growth and preserve the shape. This can be done in April or May, just before the trees start to grow.

dug with ball of earth. We make extra charge for this, but wbere it is possible to do so, it well repays the extra expense.

\section{CLASSIFICATION OF ORNAMENTAL TREES}

For the convenience of purchasers we have classifled the various ornamentai trees as follows:

Class I-Trees Sultable for Street and Avenue Planting:

Acer Saccharinum (Silver Leaved Maple).

Acer Platanoides (Norway Maple).

Acer Saccharum (Sugar Maple).

Fraxinus Alba (White Ash).

Liriodendron (Tulip Tree).

Platanus Occidentalls (American Sycamore)
Platanus Orientalis (European Sycamore).

Platanus Orientalis (European Sycamore).
Populus Fastigiata (Lombardy Poplar).

Populus Fastigiata (Lombardy Poplar).

Populus Nigra (Grecian Poplar).

Quercus Palustris (Pin Oak)

Quercus Rubra (Red Oak)

Salisburia (Maiden Hair)

Tilia Americana (American Llnden),

Tilia Europaea (European Linden).

Tilia Platyphyllos (Large Leaved European Linden).

Ulmus Americana (American Elm).

Class II-Trees with Cut or Lanceolated Follage: Acer Saccharinum var. Weirii (Weir's cut-leaved Maple). Birch).

Sorbus Quercifolia (Oak-leaved Mountain Ash).

\section{Class III-Trees with Colored Follage:}

Acer Platanoides var. Schwedierii (Schwedier's Maple). Purple foliage in spring.

Prunus Pissardi (Plum). Purple foliage.

Populus Alba Bolleana (Poplar). Silver foliage.
Salix Regalis (Silver Wiliow). Silver foliage.
Class IV-Trees Prodnclng Consplcuons Flowers:

Aesculus (Horse Chestnut).

Aralia (Angelica Tree).

Cataipa Speclosa.

Chionanthus (White Fringe).

Cornus (White and Red Flowering Dogwood).

Crataegus (Thorn). White and Scarlet Flowering.

Cytisus (Golden Chain).

Halesia (Silver Bell),

Liriodendron (Tulip Tree).

Magnolia, in variety.

Persica (Peach). Doubie Flowerlng.

Prunus Triloba (Plum). Double Flowering.

Pyrus (Crab) in variety.

Catalog.

Class $\mathbf{V}$-Weeping Trees. See Weeping Trees in this catalog.

For sizes larger or smaller than quoted hereln, write ns. We frequently have specimen stock of certain varleties and always scribe the class of stock desired and we will qnote on such as we can supply.

In order to make it easier for planter to select trees for particuiar purposes, we have adopted letters to denote the various ciasses, as follows:

$\mathrm{T}$-Denotes trees that attain a height of 50 feet and over at maturity.

M-Denotes trees that attain a height of 25 to 40 feet at maturity turity.

$\mathrm{S}$-Denotes trees that attain a height of 8 to 15 feet at ma-

D-Denotes trees that attain a height of 2 to 8 feet at maturity.

A House Is only a Bnilding, unless surrounded by Trees and Plants, then It's a Home. 


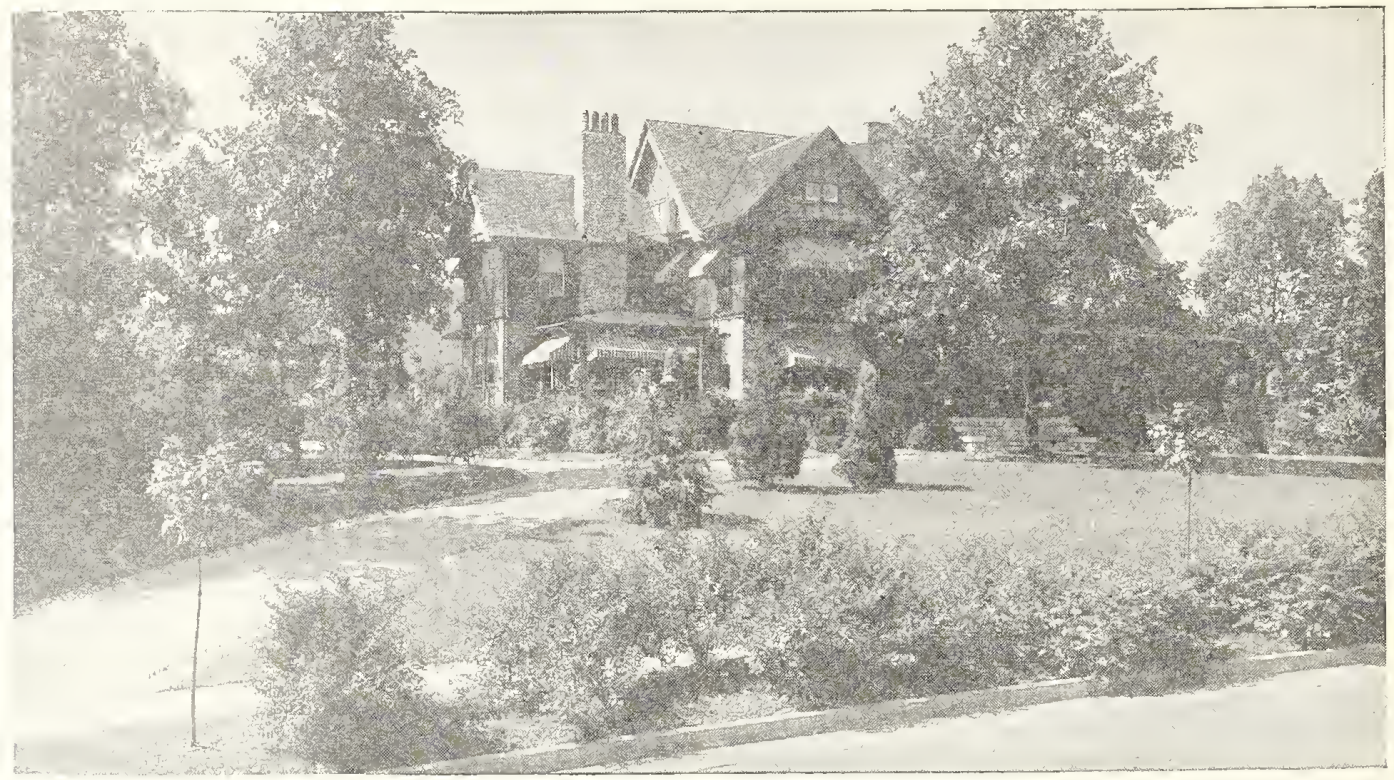

Modern Home After Planting the Weber Way

\section{Deciduous Ornamental Trees}

\section{Nomenclature}

The names of Trees, Shrubs, Perennials, etc. published in this Catalog are in accordance with the recommendations adopted by the American Jolnt Committee on Horticultural Nomenclature, representing the American Association of Nurserymon, Ornamental Growers' Association, American Society of Ladscape Architects, American Pharmaceutical Association. American Association Park Superintendents.

\section{ACER-MAPLE}

A. platanoides. (Norway). T.-A native of Europe. Its large, compact babit, broad, deep green shining foliage, render it one of the most desirable species for streets, parks and lawns.

Each 10

1 to $11 / 4$-in., $8-10 \mathrm{ft} \ldots \ldots \ldots \ldots \ldots . \$ 40 \quad \$ 42.50$

$11 / 4$ to $11 / 2$-in., $8-10 \mathrm{ft} . \ldots \ldots \ldots .6 .5 .50$ 5. 52.50

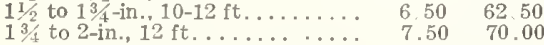

A. platanoides var. Schwedlerl. (Purple Nor way Maple.) M.-The beautiful leaves attract attention at all seasons, but are especially fine in spring, when their gleaming red and purple con purple contrasts brigti with the delicate green of other in autumn golden-yellow.

Eacb Per 10 $6-8 \mathrm{ft}$.

A. saccharinum. (Silver Leaved) T.-A bardy rapid-growing native tree of large size, valuable planting.

Each Per 10 Per 100 8 to $10 \mathrm{ft}, 1$ to 1 i 1 in..... $\$ 1.50 \quad \$ 12.50 \$ 100.00$ $11 / 4$ to $11 / 2$ inch, 8 to $10 \mathrm{ft} \quad 3.00 \quad 2500 \quad 200.00$ $1 \frac{1}{2}$ to $1^{3}$ inch, 10 to $12 \mathrm{ft}$. $4.50 \quad 35.00 \quad 300.00$ $13 / 4$ to 2 inch, 12 to $14 \mathrm{ft}$. $5.00 \quad 42.50$

A. saccharinum var. Wierii. (Wier's Cutleaved Silver Maple.) T.-One of tbe best cut or dissected-leaved trees; being of rapid growtb it soon produces an effect. Young sboots slender and drooping.

8 to $10 \mathrm{ft}$., $11 / 4$ to $11 / 2$ in.. $\begin{array}{cc}\text { Each } & 10 \\ 2.50 & 22.50\end{array}$

A. saccharum (Sugar). T.-A very popular American tree, and for its stately form and fine foliage justly ranked among the very best, botb for lawn and avenue.

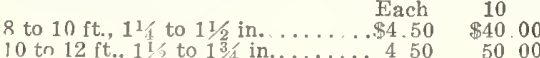

\section{AESCULUS-Chestnut}

A. hippocastanum (Horse). T.-This magnificent, large-sized tree has no superior on the lawn. In the spring it is profusely covered with panicles of white flowers dotted witb red.

$$
\begin{aligned}
& 6 \text { to } 8 \mathrm{ft} \ldots \ldots \ldots \ldots \ldots \ldots \ldots \ldots \ldots \ldots \ldots \ldots \ldots \ldots \ldots \\
& 8 \text { to } 10 \mathrm{ft} \ldots \ldots \ldots \ldots
\end{aligned} \quad \begin{array}{r}
\$ 4.50 \\
6.00
\end{array}
$$

\section{AILANTHUS-Tree of Heaven}

A. altissima (glandulosa), T.-A rapid-growing, lofty tree, long, elegant foliage. A distinct ornamental tree with pinnate foliage, exempt fom diseases and insects. Useful in producing tropical effects.

6 to $8 \mathrm{ft}$

Each 8 to $10 \mathrm{ft} \ldots \ldots \ldots \ldots \ldots \ldots \ldots \ldots \ldots \ldots \ldots \ldots, \quad \$ 2.00$

\section{AMELANCHIER-Mespilus}

A. canadensis. (Service Tree or Shadblow.) M. - A small, slender tree tbat bears a profusion of drooping spikes of wbite flowers, rendering the tree quite conspicuous about tbe time that sbad are running up the river. Also grown for its fruit.

2 to $3 \mathrm{ft} \ldots \ldots \ldots \ldots . \quad \begin{aligned} \text { Eacb } & \text { Per } 10 \\ \$ 0.90 & \$ 7.50\end{aligned}$

$1.25-10.00-\cdots \cdots$

\section{AMYGDALUS-Almond, Peach} and Plum

Amygdalus. (Almond Double-flowering.)-See Deciduous Shrubs.

A. Perslca alba. (Double-flowering Peach.) S.-Very ornamental. Flowers pure wbite and double; superb.

Each Per 10

4 to $5 \mathrm{ft} . \ldots \ldots \ldots \ldots \ldots$. $1.60 \quad 14,00$

A. Persica rubra. (Double red-flowering Peacb.)

S.-Flowers semi-double, brigbt red, fine.

Eacb Per 10

4 to $5 \mathrm{ft} \ldots \ldots \ldots \ldots \ldots \ldots 1.60 \quad 14.00$

A. triloba. (Double-flowering Plum.) D.A beautiful small tree or shrub of fine babit with elegant, double, rosy flowers, set very closely on slender branches.
ARALIA-Angelica Tree

A. spinosa. (Hercules Club.) S.-A very showy sort, yet whicb produces suckers quite freely Immense clusters of small, wbite flowers in July.

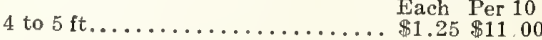
A. pentaphylla. See Acanthopanax, Deciduous Sbrubs.

\section{BETULA - Birch}

B. alba. (European Wbite Birch, T-Of which Coleridge says: "Most beautiful of forest trees, 6 to $8 \mathrm{ft} \quad$ Each Per 10 Per 100 to $8 \mathrm{ft} \ldots \ldots \ldots \ldots \ldots \ldots . \$ 3.00 \$ 27.50$

B. alba laciniata pendula. (Weeping Cutleaved Bircb.) See Weeping Trees.

\section{CATALPA-Indian Bean}

C. bignonioides nana. (Chinese Catalpa.) (Bungei.) D.-A small species that grows 8 to 10 feet higb, as broad, forming a broad head clotbed witb a dense mass, heart-shaped leaves. Among our hardy trees tbere are but few, if any, that are more effective for park or lawn. Grafted on stems of the common Catalpa 5 to 6 feet fror the ground, forming an umbrella-sbaped top.
Each Per 10 Per 100 2-year beads, standard... $\$ 2.50 \$ 22.50 \$ 200.00$ 1-year beads, standard.... $2.00 \quad 17.50 \quad 150.00$

C. speciosa. (Western.) T.-One of the most rapid growers. Large beart-shaped, downy leaves. and compound panicles of white flowers, tinged witb violet and dotted with purple and yellow. witb violet and dotted with purple and yellow. 8 to $10 \mathrm{ft} \ldots \ldots \ldots \ldots \ldots \ldots \$ 1.50 \$ 13.50 \$ 120.00$

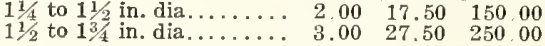

\section{CERCIS-Red Bud}

C. canadensis. (American Judas.) M.-A small tree of irregular rounded form, with pretty foliage, and very showy wben in bloom; the branches and twigs are covered with a dense mass of small pink flowers before the leaves expand. Each Per 10 Per 100

3 to $4 \mathrm{ft} \ldots \ldots \ldots \ldots \ldots \ldots \$ 1.50 \$ 13.50$

\section{CERASUS-See Prunus}

\section{CIIIONANTHUS - White Fringe}

C. vlrginica. S. -A small native tree, with asb-like leaves and clusters of snow-white flowers, resembling an elegant fringe.

3 to $4 \mathrm{ft} . . .$. Each Per 10 

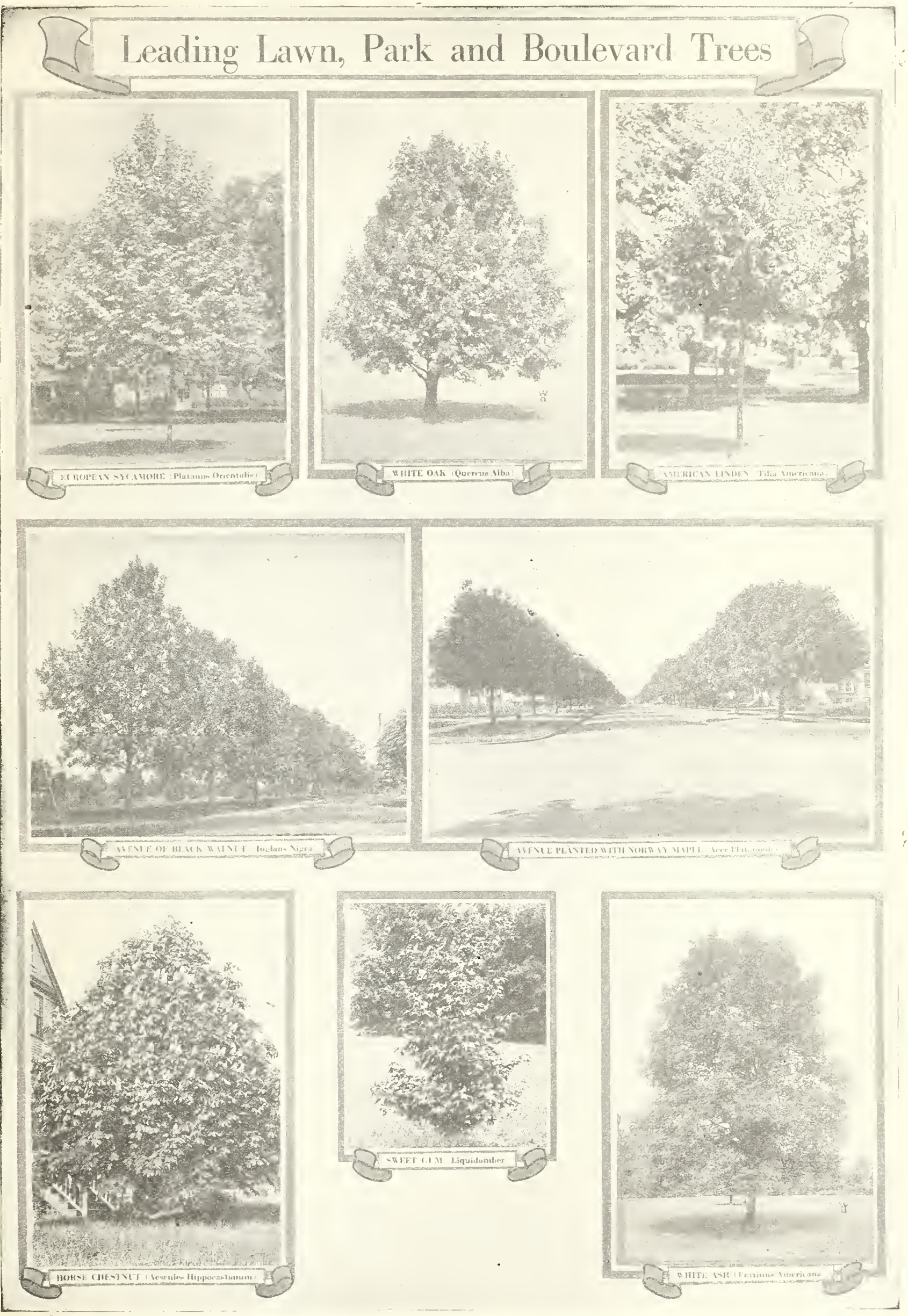


\section{DECIDUOUS TREES-Con.}

\section{CORNUS-Dogwood}

C. Alorida, (White Flowering.) M.-An American species, of spreading irregular form, growing from 16 to 20 feet high. The flowers are produced In spring before the leaves appear; they are white and very showy. Popular.

3 to $4 \mathrm{ft}$

Each Per 10 Per 100

$\$ 2.00 \$ 17.50$

C. florida rabra. (Red Flowering.) M.-Recently introduced. A variety producing flowers suffused with bright red; blooms when quite young. One of the finest flowering trees.

3 to $4 \mathrm{ft}$ Each Per $10 \quad \ldots \ldots$

\section{CRATAEGUS-Thorn}

C. coccinea. (Scarlet-fruited Thorn.) M.A fine natlve variety. Single white flowers in spring, scarlet fruit in autumn.

$$
\text { Each Per } 10
$$

3 to $4 \mathrm{ft} . \ldots \ldots \ldots$

c. cordata. (Washington Thorn.)-Native thorn, white-flowering, small red fruit. Broad ovate leaves, grows from 6 to 8 feet.

$$
3 \text { to } 4 \mathrm{ft} \ldots \ldots \ldots \ldots \ldots \ldots . \$ 2.00 \quad \$ 17.50
$$

C. crus-gall (Cocour Thorn) known native thorn: has long sharp spines or thorns; fruit bright red; valuable for hedging.

3 to $4 \mathrm{ft} \ldots \ldots \ldots \ldots \ldots . \ldots . . \ldots 2.00 \quad \$ 17.50$

C. oxycantha var. alba plena. (Double White

Thorn.) S.-Has small double white flowers.

A highly ornamental variety, on account of both foliage and flowers. Makes a striking contrast when planted with the double scarlet.

$$
\text { Each Per } 10
$$

C. oxycantha var. Paulii. (Paul's Double C. oxycantha var. Paulii. (Paul's Double
Scarlet Thorn.) S.-Flowers bright carmine red Scarlet Thorn.) S.-Flowe
Superior to any of its color.

3 to $4 \mathrm{ft} \ldots \ldots \ldots \ldots \ldots \ldots \$ 33.00$ Each 10

\section{FRAXINUS-Ash}

F. americana. (American White.) M.-A rapid-growing native tree, valuable for planting along streets or in parks; may be extensively planted for timber; largely used in the manu. planted for timber; largely used 8 to $10 \mathrm{ft}$., $11 / 4$ to $11 / 2$-in... $\$ 2.50$ Per 10 Per 100 10 to $12 \mathrm{ft}$., $1 \frac{1}{2}$ to $1 \frac{3}{4}$ in... $3.00 \quad 27.50 \quad 250.00$ For Mountain and Oak-Leaved Ash-See Sorbus-Deciduous Trees.

\section{GINKGO-Salisburia (Maiden Hair Tree)}

G. biloba. T.-A native of China and Japan, forming a medium or large tree; leaves fan-shaped. Tree of a rapid growth and belonging to the Conif-

Each Per 10 Per 100 8 to 10 ft to $11 . . . . . \$ 2.50 \$ 22.50 \$ 200.00$

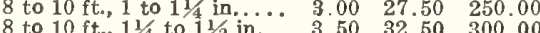
10 to $12 \mathrm{ft} ., 1 \frac{1}{2}$ to $1 \frac{3}{4}$ in... $4.00 \quad 37.60 \quad 350.00$

\section{GYMNOCLADUS-Kentucky Coffee}

G. dioica. (Canadensis.) M.-A strikingly ornamental, irregular, open-topped tree, with peculiar rough-barked and twigless branches and Immense broad, double-compound foliage of a peculiar bluish-green color. The flowers are white, in open racemes, followed by immense long. brown pods. A picturesque and desirable

8 to $10 \mathrm{ft}$ $\ldots \ldots \$ 2.50 \$ 22.50$

\section{HALESIA-Silver Bell}

Brown light green foliage, dense growing trees of small size and well adapted for lawn culture and grouping with other plants. Their chaste, pure white flowers are produced in abundance along tbe entire length of the branches as the leaves appear in the spring, and give a very charming picture. Best grown in well-drained soil in somewhat shetered position.

H. tetraptera. (Carolina.) S.-The hardiest species. Very choice. 3 to $4 \mathrm{ft}$.

Each Per 10

$\$ 1.50 \quad \$ 12.50$

\section{See Nut Trees. \\ JUGLANS-Walnut \\ LIQUIDAMBER-Sweet Gum}

L. styraclflua. T.-A large native tree, with rough, corky bark and shining, deep lobed, starshaped leaves, changing to deep crimson in the autumn.

4 to $5 \mathrm{ft}$.

Each Per 10

5 to $6 \mathrm{ft}$

$\begin{array}{rr}\$ 2.50 & \$ 22.50 \\ 3.00 & 27.50\end{array}$

6 to $8 \mathrm{ft} . \cdots 30$

The Gum, like the Tulip and Birch, are bard trees to transplant: we recommend digging the larger sizes with ball and burlapping. We charge extra for this work, according to size tree.

\section{LIRIODENDRON-Tulip Tree}

L. tullpifera. T.-One of our very largest native trees, with large, smooth, shining leaves, greenish-yellow flowers and an umbrageous head. Each Per 10
$\$ 2.00$ $\begin{array}{rrr}6 \text { to } 8 \mathrm{ft} \ldots \ldots \ldots \ldots \ldots \ldots \ldots \ldots & \$ 2.00 & \$ 17.50 \\ 8 \text { to } 10 \mathrm{ft} . \ldots \ldots & 22.50\end{array}$

\section{MAGNOLIA}

M. glauca. (Sweet Bay or Swamp Magnolia.) S.-When planted in moist soil this makes a handsome tree of medium size. Its leaves are glossy, laurel-like, almost evergreen. In June its pure white flower-cups are lovely and grand.

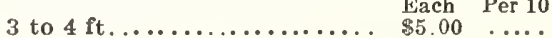

\section{MAGNOLIA - Chinese Species and} Their Hybrids

Owing to Government embargo we are unable to lmport this class of Magnolias.

\section{MALUS-Crab}

M. ioensis. (Bechtel's Double Flowering Crab.) S.-The beauty and delicate fragrance of the bloom of the sweet-scented crab is a theme for poets and this new variety is a gem among hardy plants. The flowers are sometimes misto increase rather than correct the delusion.

Each Per 10 3 to $4 \mathrm{ft} . \ldots \ldots \ldots \ldots \ldots \ldots \ldots \ldots \ldots \ldots$
4 to $5 \mathrm{ft} \ldots \ldots \ldots \ldots \ldots \ldots \ldots$

M. floribunda (Single-Flowering Crab). S.Flowers beautiful carmlne in bud; white when open; May. Fruit very ornamental in autumn. 4 to $6 \mathrm{ft}$. Each................ 1.75 M. Atrosanguinea (S), - Red flowers.

4 to $5 \mathrm{ft}$ Each. M. Coronarius (S).-
used in landscape work.

Each Per 10

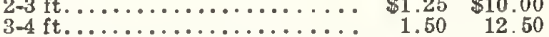

M. Parkmannii (S) (Parkman's Crab.).-Dwarf habit, foliage dark green, hangs on late; flowers double dark rose.

$5 \mathrm{ft}$ Each................... $\$ 2$

Malus Purpurea-A form of Floribunda with darker red flowers.

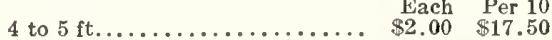

\section{PLATANUS-Sycamore or Plane}

The Sycamore is probably the hardiest of all street trees for our larger cities. It can stand more abuse than any other tree we know of, ls not affected with many of the injurious insect stand the smoke and gases better than can most other ornamental street trees. We recommen the Sycamore for general planting in large cities, manufacturing cities and cities lying along river and lowlands where the other finer trees would stand very little chance of surviving for any length of time.

P. occidentalis. (American Plane.) T.-A tree of the largest size, growing rapidly, very ornamental and entirely hardy. Fine for street plant-

P. orientalis. (European Plane.) T-A lofty, wide-spreading tree; large five-lobed leaves; val-
uable for its bandsome foliage and free growth; makes an excellent street tree.

This is undoubtedly the best variety of the Sycamores for general street planting, on account of its more compact srowth than the American variety. Holds its foliage later in the fall. European and American

6 to $8 \mathrm{ft}$

8 to $10 \mathrm{ft}$.

$\ldots \ldots \ldots . \$ 2.00 \$ 17.50 \$ 150.00$ $\begin{array}{lllll}1 / 4 & \text { to } 11 / 2 \text { in. dia........... } & 3.00 & 25.00 & 200.00 \\ 3.75 & 35.00 & 300.00\end{array}$ $1 / 2$ to $13 / 4$ in. dia......... $4.50 \quad 40.00$

2 to $21 \%$ in dia $\quad 7.50 \ldots . . . \cdots$

\section{POPULUS-Poplar}

P. alba pyramidalis. (Bolleana) (Silver). M.New pyramidal form leaves dark green on upper side, brilliant silver underneath. Very beautiful. Each Per 10

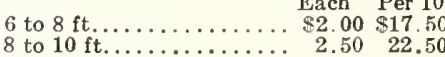
$2.50 \quad 22.50 \quad \ldots \ldots$

P. deltoides monilifera. (Carolina Poplar) (Carolina.) M.-A vigorous, healthy native tree of rapid growth, pyramid in form, with large, glossy leaves; valuable for park or street planting 6 to $8 \mathrm{ft}$. 1 to $11 / 4$ in Each Per 10 Per 100 8 to $10 \mathrm{ft} ., 11 / 4$ to $1 \frac{1}{2} \mathrm{in}$... $\quad .80 \quad 7.00 \quad 60.00$ 10 to $12 \mathrm{ft}$., $1 \frac{1}{2}$ to $13 / 4$ in.. $1.30 \quad 11.50 \quad 100.00$

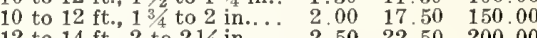
12 to $14 \mathrm{ft} ., 2$ to $21 / 2 \mathrm{in}$... $2.50 \quad 22.50 \quad 200.00$

P. nigra italica. (Lomhardy Poplar) T.-This grows to an immense height, and is remarkable for its columnar growth. In landscape work breaks the monotony of the lower, round-topped trees. One of the characteristic trees of Lombardy and other parts of Italy.

6 to $8 \mathrm{ft}$.

Each Per 10 Per 100 8. $10 . . . \cdots . . . \$ 0.90 \quad \$ 8.00 \quad \$ 70.00$

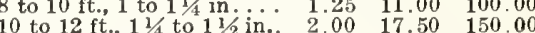

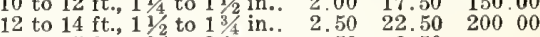
14 to $15 \mathrm{ft} ., 13 / 4$ to $2 \mathrm{in} . . .3 .50 \quad 32.50 \quad \ldots$.

$15 \mathrm{ft}$. and up, 2 to $21 / 2$ in.. $5.00 \quad \ldots$.

\section{PRUNUS-Plum, Cherry}

Comprises the genus cerasus (Cherry) and Prunus (Plum). These contain many beautiful flowering and bright foliaged varieties.

P. avium alba plena. (Double Flowering Cherry) (Cerasus.) M.-The double white fowers, like little roses, cover the tree completely. Each

4 to $5 \mathrm{ft} . \ldots \ldots \ldots \ldots \ldots . \$ 3.00 \ldots \ldots . . .$.

P. cerasifera Pissardii. (Purple-leaved Plum.) S. - A very remarkable and beautiful tree with black bark and dark purple leaves, remaining so until late in the fall.

3 to $4 \mathrm{ft} \ldots \ldots \ldots \ldots \ldots$ Each Per 10

4 to $5 \mathrm{ft} . \ldots \ldots \ldots \ldots \ldots \ldots . \ldots 1.40 \quad \$ 12.50$

P. triloba. See Àmygdalus in Deciduous trees.

\section{QUERCUS-Oak}

Q. palustris. (Pin Oak.) M.-Foliage deep green, finely divided; assumes a drooping form for street planting.

Each Per 10 Per 100

$11 / 4$ to $11 / 2$ in. dia....... \$3.75 $\$ 35.00 \$ 325.00$ $11 / 2$ to $1 \frac{3}{4}$ in. dia........ $4.50 \quad 42.50 \quad 400.00$ Q. rubra (Red Oak.) T.-An American species, of large size and rapid growth, foliage purplish red in the fall.

$11 / 4$ to $11 / 2$ in. dia....... $\$ 3.75 \$ 35.00$ $11 \%$ to 18 in dia........ 4.50 42.50 $\cdots$ 18 to 2 in. dia.......... $5.50 \quad 52.50 \cdots$ 


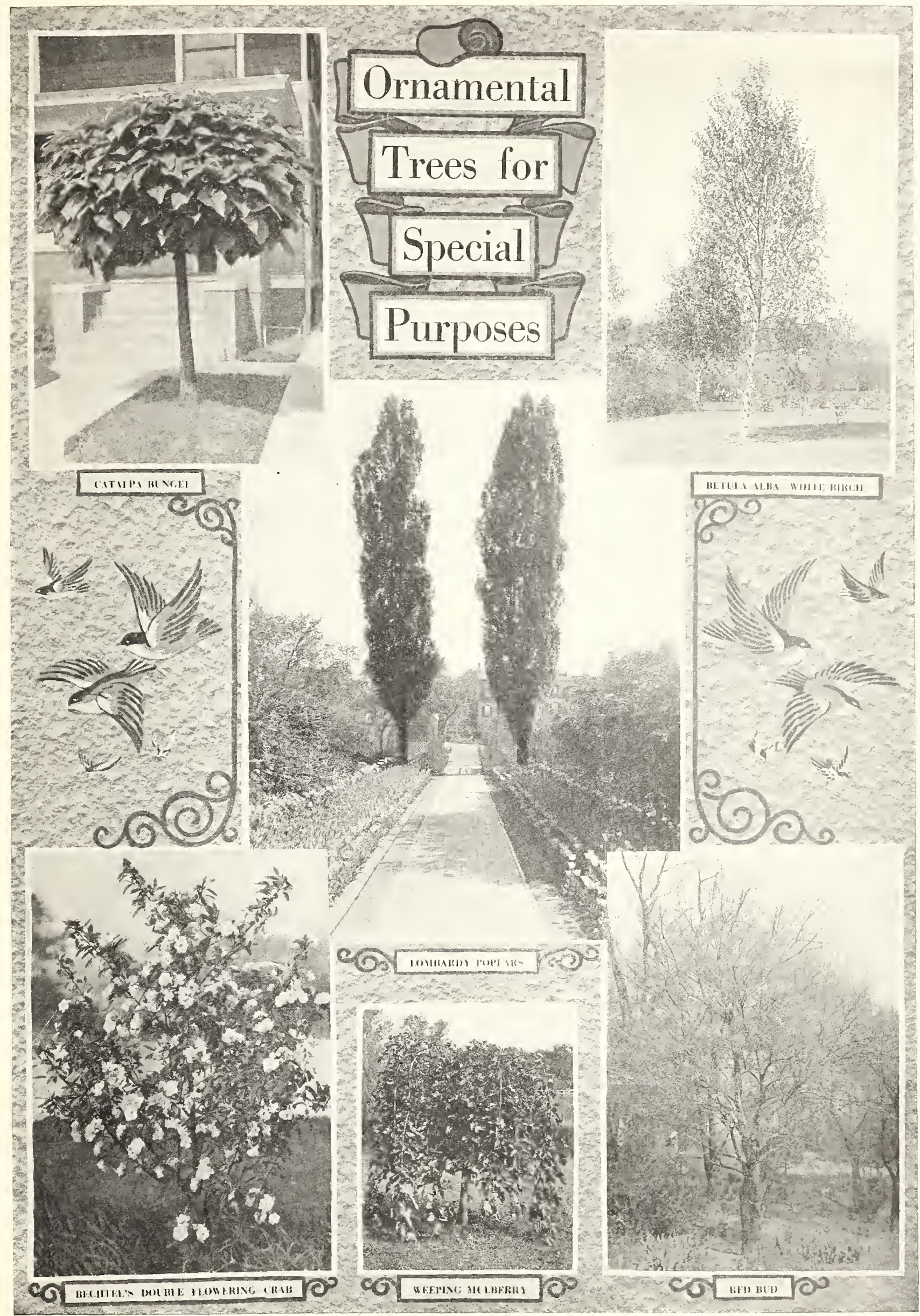




\section{DECIDUOUS TREES-Continued}

\section{SALIX - Willow}

All Willows should be pruned annually for best results.

S. caprea. (Goat Willow.) S.-Also known leaves; very useful for early effects.

3 to 4 Each Per 10

3 to 4 ft.............. \$0.75 $\$ 6.50 \quad \ldots \ldots$.

S. pentandra. (Laurel Willow.)-A fine ornamental tree, with large shining leaves.

4 to $5 \mathrm{ft}$.

Each Per 10

S. vitellina aurea. (Golden Willow.) M.Grows into a massy low-headed tree. Light green leaves and brilliant golden-yellow bark in winter. Each Per 10 5 to $6 \mathrm{ft} \ldots \ldots \ldots \ldots \ldots \ldots . \ldots .75 \quad \$ 650 \ldots \ldots$

S. vitellina britzensis. (Salmon Barked Willow.) L. - A form of the above with yellow bark on the younger wood, tinted with red.

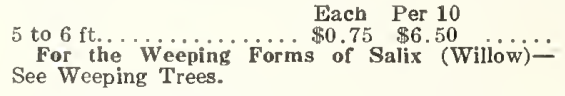

\section{SORBUS-Mountain Ash}

S. aucuparia. M.-A small tree with shining, pinnated leaves and large cymes of white flowers, followed by clusters of bright red fruit.

Each Per 10
Fallowed by clusters of bright red ruit. 5 to $6 \mathrm{ft} . \ldots \ldots \ldots \ldots \ldots \ldots \ldots 2.00 \$ 17.50 \quad \ldots \ldots$ S. quercifolia. (Oak-Leaved Mountain Ash.) M.-A hardy tree of pyramidal habit. Foliage simple and deeply lobed, bright green above and downy beneath. A fine lawn tree.

6 to $8 \mathrm{ft}$. . . . Each Per 10

\section{TILIA-Linden} T. americana. (American.) T.- A fine pyra-
midal tree with large-sized leaves and fragrant flowers.

flowers. Each Per 10

8 to $10 \mathrm{ft}, 11 /$ to $11 / 2$ in... $\$ 300 \$ 2750$ 10 to $12 \mathrm{ft}$., $11 / 2$ to $1^{3 / 4}$ in.. $3,50 \quad 30.00$
T. platyphylos. M.-A tree of about the same size as T. vulgaris, but readily distinguished from it by its larger and rougher leaves.

thach Per 10 Per 100 8-10 ft., $11 / 4$ to $1 \frac{1}{2}$ in. dia. $\$ 3.00 \$ 27.50 \quad \ldots .$. 10 to $12 \mathrm{ft}$., $1 \frac{1 / 2}{2}$ to $1 \frac{3}{4}$ in.. $3.5030 .00 \quad \ldots .$.

T. vulgaris (Europaea). M.-A fine pyramidal tree, with medium-sized leaves and fragrant flowers.

8 to $10 \mathrm{ft} 11 / 4$ to $11 /$ in Each Per 10 Per 100 10 to $12 \mathrm{ft}, 11 / 2$ to $13 / 4$ in. $350 \quad 30.00 \quad \ldots .$.

\section{ULMUS-EIm}

U. americana. (American.) T.-The noble, drooping, spreading tree of our woods. One of the grandest of park and street trees. Select specimens.

8 to $10 \mathrm{ft} .-1 \frac{1}{4}$ to $1 \frac{1}{2} \mathrm{in}$.

dian. $\$ 2.75 \$ 25.00 \$ 200.00$ 10 to $12 \mathrm{ft} .-1 \frac{1}{2}$ to $1 \frac{3}{4} \mathrm{in}$. $3.50 \quad 32.50 \quad 300.00$ 10 to 12 ft- $-13 / 4$ to 2 in. dia................... $4.50 \quad 40.00 \quad \ldots \ldots$ 12 to $14 \mathrm{ft}-2$ to $2 \frac{1}{2}$ in. dia................ $5.00 \quad 47.50 \quad \ldots$

\section{WEEPING DECIDUOUS TREES}

\section{ACER-MAPLE}

A. saccharinum var. Wierii (Wier's Cut-leaved Maple).-See Deciduous Trees.

\section{BETULA-Birch}

B. alba laciniata pendula (Cut-leaved Weeping Birch.) T.-Trunk straight, slender, white as snow; branches hanging in long pendulous thread from a great height; leaves finely cut; a universa favorite.

6 to $8 \mathrm{ft}$.

\section{MORUS-Mulberry}

M. alba pendula (Weeping Mulberry.) S.A graceful and beautiful hardy tree, forming perfect umbrella-shaped head, with long, slender willowy branches, drooping to the ground and gracefully swaying in the wind. Foliage small-lobed and of a delighțul fresh, glossy green. Admirably adapted to cemetery planting.

1 year heads........... $\$ 3.75$ Per 10 Per 100

\section{SALIX-Willow}

S. babylonica (Bahylonian Wecping Willow). M.-A well-known and most graceful tree of large size. Its fresh, bright green tint and long, wavy branches make it very attractive.

Each Per 10 Per 100 6 to $8 \mathrm{ft} \ldots \ldots \ldots \ldots \ldots \ldots \$ 1.25 \$ 11.00 \$ 95.00$

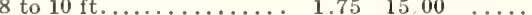

S. blanda (Wisconsin Weeping Willow). M. Of drooping habit and beautiful form. The most hardy of all Weeping Willows.

Each Per 10.

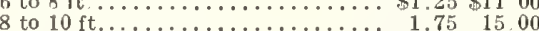

S. elegantissima. (Thurlow's Weeping Willow.) M.-Larger, hardier and more spreading than the Babylonica. A fine varjety where a large size tree is desired.

Each Per 10 Per 100 $\$$ to $8 \mathrm{ft} . \ldots \ldots \ldots \ldots \ldots \$ 1.25 \quad \$ 1100 \quad \$ 95.00$

\section{SORBUS-ASII}

W. P. Mountain Ash.......... $\begin{array}{r}\text { Each } \\ 5.00\end{array}$

$$
\text { ULMUS-EIm }
$$

U. var. Camperdown Pendula (Camperdown Weeping Elm). S.-One of the finest weeping tree for the lawn. With broad foliage and branches drooping gracefully to the ground.

2-year heads, $5 \mathrm{ft}$. stems....... $\$ 5.00 \quad$ Per 10

NoTECE
In the future our Office, Nurscry
and Greenhouses will be closed on
Suudays and Legal Holidays during
the months of June, July, August,
September, December, January and
February. During March, April,
May, Octroer and November we will
be open from 8 to $11: 30$ a. m. on
Sundays to accommodate customers
who can not come on week days.

\section{A N D S CA P I N G}

Our business is the growing and supplying of trees and plants of all kinds described in our catalogue for Landscape work.

If you are contemplating any Landscape work write us, giving description of what is desired and we will be pleased to refer you to someone who can take care of your proposition and make estimate of cost, etc.

It will save time it you will make a sketch showing size of grounds, location of building, present driveways, walks, etc. Indicate any large trees that may be on the place, give name of same, and if possible send us photographs showing front and sides of house and grounds. We can then answer more intelligently.

A few dollars spent for trees and shrubs to improve your property will increase its value far more than the expenditure.

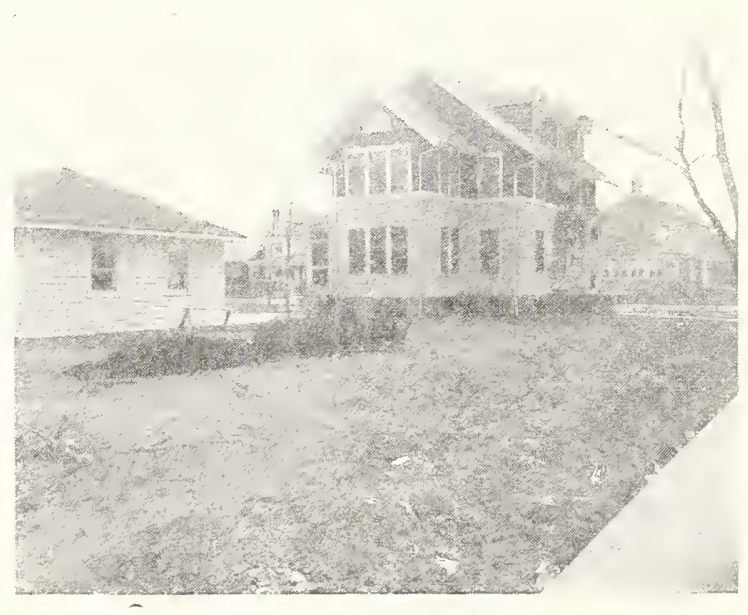

Before Consulting a Landscape Architect

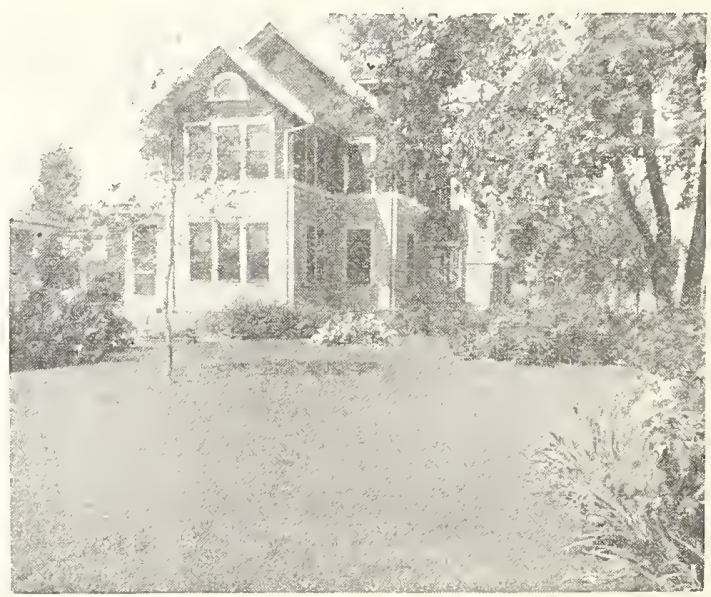

After Planting With Trees and Shrubbery (This is now a home.) 


\section{Deciduous Ornamental Shrubs}

Our collection of Hardy Shrubs is one of the finest and most complete in the West. To parties desiring to lay out new grounds, or to fll out missing sorts, we would kindly ask correspondence.

To make it easier for planter to select slirubs for particular purposes we have adopted letters to denote the average lieight to which the various shrubs grow at maturity.

T-Denotes shrubs tliat grow 12 to 15 feet high.

L-Denotes shrubs that grow 8 to 12 fcet high.
M-Denotes shrubs that grow 6 to 8 feet high.

S-Denotes shrubs that grow 3 to 6 feet high.

\section{Classification of Ornamental Shrubs}

shrubs classified as to height, color of flower and time of blooming.

\section{SHRUBS THAT GROW 12 TO 15 FEET HIGH.}

NAME.

A morpha fruiticosa

Eleagnus angustifolia

\section{SHRUBS THAT GROW 8 TO 12 FEET HIGH.}

NA ME.

Colutea arborescens. .

Euonymus americanus.

Euonymus europaeus.
Exochorda grandiflora

Hibiscus in variety.

Philadelphus coronarius.

Philadelphus coronarius fi. pl.

Philadelphus coronarius grandiflorus.

Philadelphus coronarius lewisil.

Rhodotypos kerrioides.

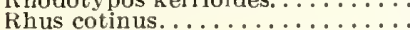

Rhus glabra.

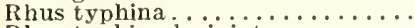

Rhus tychina laciniata

Sambucus canadcnsis. .

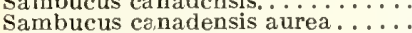

Sambucus nirra

Sambucus racemosus

Tamarix africana

Tamarix gallica..

Tamarix odissina estivalis

Tamarix tetandra purpurea

Viburnum lantana.

Viburnum lentago..

Color of Flower, BloOMING

Purple............... June.

TIME OF

Reddish-yellow ....July

Small yellow......... May.

Small yellow......... May.

White.............. May

Red, white, purple,

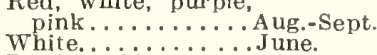

Double white.........June.

White. . . . . . . . . June.

White............... June

white..........

Purple............... Midsummer.

Crimson secd : . . . . . Fall.

Crimson seed....... Fall.

Crimson seed...... F Fall.

White........... June.

White............... June

White. . . . . . . . . June.

White. ............ June.

Rose-purple........ April.

Pink............... May.

Bright carmine.........July

Purplish pink...... July

White...................

Creamy white..... May.

\section{SHRUBS THAT GROW 6 TO 8 FEET HIGH.}

NAME.

Calycanthus.

Cornus alba........

C. Eleagantissima var

Cornus mas.

Cornus sanguinea

Cornus stolonifera aurea.

Corylus..

Deutzia in variety

Forsythia in variety

Hydrangea paniculata grandi

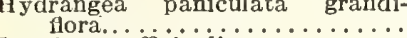

Jasminum officinalis.

Jasminum nudiflorum

l, agerstroemia ........

ligustrum amou

Ligustrum ibota

Lonicera fragrantissima.

Lonicera morrowii.

Lonicera tartarica aibà.

Lonicera tartarica rosea.

Lonicera tartarica rubra

Philadelphus lemoinei.

Physocarpus opulifolia.............

Rhysocarpus opulifolia luteus. . . . .

Ribes gordonianum.

Ribes odoratum...

Ribes sanguineum
Robenia hispida.
CIME of

Maroon-purple. .... June.

Green-white....... June.

Green-white..... June.

Green-white...... June.

Yellow . ......... May.

Green-white..... June

Green-white....... June.

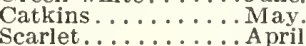

White. . . . . . . . . May-J une.

Yellow ............. March-A pril

Yellow............ Sept.-Oct.

White.......... July to Oct. White........... Midsummer.

Yellow........... Midsummer.

Rose, red, white.... July-A ugust.

White...........June

White............June

White...........June.

Pink.................

Pink..............May.

White...........June.

Rose............June.

Red..............June.

White.............June.

White........... June

White........... June-July.

Orange-red ......... May-June.

Golden-yellow....... May-June.

Crimson. . . . . . . . . . . . . . . June.June.

\section{SHRUBS THAT GROW 6 TO 8 FEET HIGH-Cont'd.}

\section{NAME.}

Spirea billardii.

Spirea Douglassi.

Spirea Fontenayij alba...

Spirea Fontenayii rosca.

Spirea Margaritea.

Spirea prunifolia.

Spirea Reevesiana.

Spirea Reevesiana if. pl.

Spirea salicifolia.

Spirea sorbifolia.

Syringa japonica.

Syringa josikea.

Syringa rothomagensis.

Syringa villosa.

Syringa vulgaris vulgaris alba

Syringa, named varieties.

Viburnum dentatum .

Viburnum molle.

Viburnum tomentosum.

Viburnum tomentosum plicatuim

Weigela in variety.

SHRUES THAT GROW 3 TO 6 FEET HIGH.

NAME.

A belia.............

Amygdalus.

Aronia arbutifolia.

Bronia melan aestivale.

Benzoin aestivale

Buddleia...

Cephalanthus

Clethra

Deutzia lemoinei

Diervilla lutea....

Eleagnus longipes

Hydrangea arborescens

Kerria japonica.

Kerria japonica fi

Lonicera ledebour

Lonicera ruprecht

Rhus canadensis.

Rubus odoratus.

Spirea Bumalda.

Spirea multifiora

Spirea Thunbergil.

Symphoricarpus rac

Vitex agnus castus.............

\section{SHRUBS THAT GROW 2 TO 3 FEET HIGH.}

NAME.

Berberis illicifolia

Berberis Thunbergil.

Callicarpa.

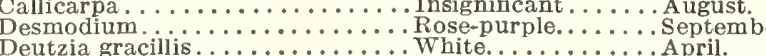

Potentilla fruiticosa. . . . . . . . . Yhellow. . . . . . . . . A All summer

Spirea callosa, var. alba.......... White................... All summer.

Spirea callosa, var. Froebelli........ Bright-rèd........... June.

Spirea callosa, var. Superba...... Rosy-red............. June

\section{SHRUBS THAT GROW 1 TO 2 FEET HIGH.}

NAME.

Berberis Thunbergii (Box) New

dwarf variety.

Ligustrum Lodense.

Lonicera nitida.

spireara piliata.

BIME OT

une.

une.

pril-May.

April.

uly-A ugust.

April

July.

May.

June.

July-August.

All summer.

June.

A pril.

August.

Midsummer.

April.

pril.

ugust-sept.

Color of Flower. Blooming.

Yellow..................

une.

TIME OF

Collor OF FIOWER OF

TIME OF ildsummer. une-July.

iidsummer.

May.

May.

une-July.

uly.

pril.

April.

April.

May.

May.

May. 


\section{SHRUBS SUITABLE FOR HEDGES.}

Baby Rambler Roses.-For low hedges in the Rose garden, all of the Baby Ramblers are excellent, giving a wide range of color Berberis Thunbergil.-One of the finest and hardiest. Berberis Thunbergii (Dwarf Box variety).-Excellent for low dwarf hedges.

Hibiscus Syriacus in varieties.-For large screens.
Ligustrum anourense (North). - The hardy Amoor River Privet for sections north of Quincy. Illinois, where the Ovalifolium Privet for sections

Ligustrum Lodense-A new dwarf hedge to talie thc place of boxwoods.

Ligustrum ovalifolium (California Privet).--The great, almost evergreen hedge so largely planted in $\mathrm{St}$. Louis.

Philadelphus in variety. - Fine for screening, and where a tall informal hedge is desired.

Rhodotypos.-Makes a beautiful informal hedge 6 to 8 feet high.

Spirea Anthony Watcrer- - Makes a beautiful low hedge, and i fower heads are kept cut as soon as petals fall will hloom all summer. Spirea Van Houttei.-Makes a beautifnl hedge or screen. Should be more largely used on large grounds.

\section{SHRUIBS WITH BERRIES IN FALL AND WINTER.}

NAME.

Aronia arbutifolla.

Aronia melancarpa.

Benzoin aestlvale.

Berberls Thunbergii. .

Callearpa purpurea.

Colutea arborescens.

Cornus alba slberica.

Cornus amomum

Cornus mas.

Cornus sangulnea.

Eleagnus a ugustlfolia

Eleagnus longipes.

Euonymus alatus.......

Euon ymus europaeus.

Ilex verticillata.

Llgustrum amourense.

Llgustrum jbota

Ligustrum Regelianum

Lonicera Bella albida.

Lonicera morrowi.

Lonicera ruprechtlana.

Rhamnus catharticus.

Rhus canadensis .

Rhus copalina.

Rhus glabra.

Rhus typhina

Rhus typhina laciniata.

Sambucus canadensis.

Sambucus nigra.

Sambucus racemosus

Symphoricarpus racemosus.

Viburnum dentatum.

Viburnum lentana.

Viburnum lentago.

Viburnum molle.
Viburnum opulus

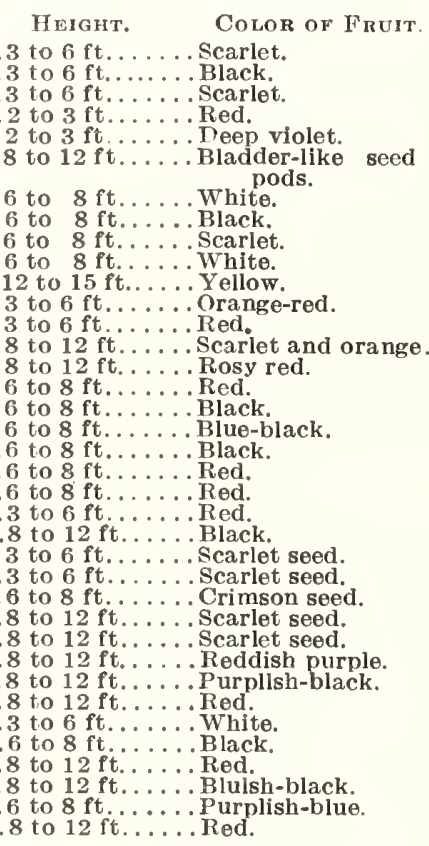

\section{SHRUBS WITH COLORED FOLIAGE.}

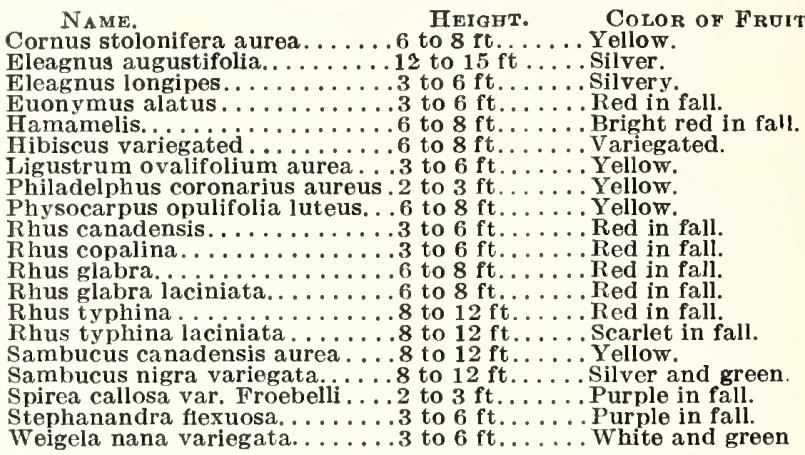

\section{SHRUBS WITH COLORED BARK IN WINTER.}

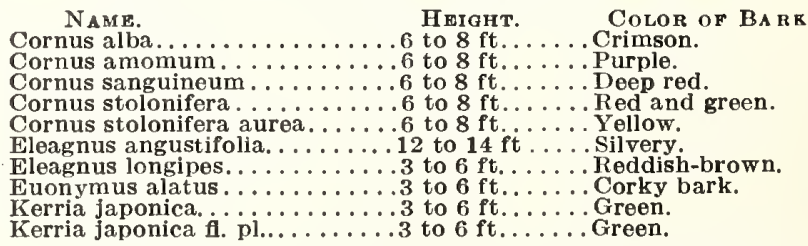

SHRUBS WITH CUT OR LANCEOLATED FOLIAGE.

NAME. HEIGHT.

Rhus glabra laciniata........6 to $8 \mathrm{ft}$

Sambucus nigra laciniata $\ldots \ldots 8$ to $12 \mathrm{ft}$

\section{SHRUBS FOR SHADY LOCATIONS.}

\section{NAME.}

Berberis Thunbergli.

Ceanothus americanus.

Clethra alnifolia.

Cornus alba siberica.

Cornus amomum.

Cornus sanguinea.

Deutzia gracillis.

Deutzia gracillis...

Doutzia lemoneil...

Hydrangea arborescens.

Hypericum Henryii.

Llgustrum (in varuety).

Rhus canadensis.

Ribes (in variety)

Rubus odoratus......................

Symphoricarpus racemosus.

Viburnum dentatum

Vlburnum lentago ......
Viburnum tomentosum

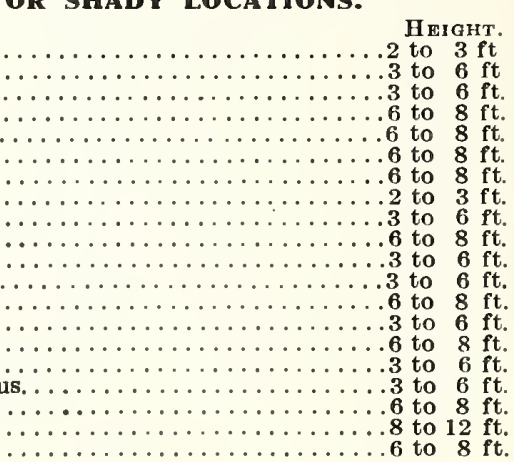

HEIGHT. to $3 \mathrm{ft}$ 3 to $6 \mathrm{ft}$. 6 to $8 \mathrm{ft}$. 6 to $8 \mathrm{ft}$. 2 to $3 \mathrm{ft}$. 6 to $8 \mathrm{ft}$. 3 to $6 \mathrm{ft}$. 3 to $6 \mathrm{ft}$ 3 to $6 \mathrm{ft}$. 8 to $8 \mathrm{ft}$. 6 to $8 \mathrm{ft}$.

\section{Ornamental Shrubs}

\section{ABELIA}

A. grandiflora. S.-In the south this shrub is evergreen, but with us it sheds its leaves during the late winter. One of the most beautiful and satisfactory plants. Foliage is dark green and glossy, with a pronounced tinge of red in the young branches; a very graceful plant, covered
with white flowers, tinged with pink. Should be given protection during winter in this climate.

Each Per 10 Per 100 $1.00 \quad \$ 9.00$

ACANTHOPANAX-Aralia

A. pentaphylium. S.-Shrub witb long. slender brancbes and few spines. Fine for rocky slopes; brancbes and few spines. Fine for rocky slopes; umbels.

Each Per 10 Per 100 2 to $3 \mathrm{ft} . \ldots \ldots \ldots \ldots \ldots \ldots \$ 0.60 \quad \$ 5.00 \quad \$ 4500$ 3 to $4 \mathrm{ft} \ldots \ldots \ldots \ldots \ldots \ldots \ldots . \quad .70 \quad 6.00 \quad 55.00$

AMORPIHA - False Indigo

A. fruticosa. T,-A large, spreading bush witb pinnate leaves and slender spikes of deep purple flowers; blooms in June, after most of tbe springfowering shrubs are over.

2 to $3 \mathrm{ft.}$ Each Per 10 Per 100

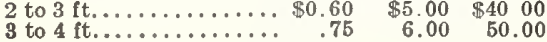

\section{AMYGDALUS-Almond}

A class of ornamental shrub or small tree introduced from the mountains of Asia Minor, and succeeding well in common garden soil. The flowers are very showy, produced in great abundance, and

grouping or for lawns.
A. nana rosea (Double Pink.) S.-Small double pink flowers borne in abundance in May.

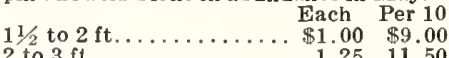

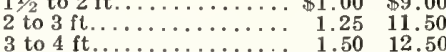
A. nana alba (Double Whlte). S. - Small double wbite flowers borne in abundance in May.

$11 / 2$ to 2 tt......... Each Per 10 2 to $3 \mathrm{ft} \ldots \ldots \ldots \ldots \ldots \ldots \ldots \ldots+1.25 \quad 11.50$

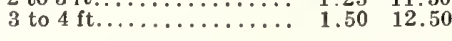

\section{ARONIA-Chokeberry}

A. arbutlfolta. S.-Uprigbt habit; very pretty in April and May with an abundance of white flowers: its fruit carries wel Into the winter.

2 to $3 \mathrm{ft} \ldots \ldots \ldots \ldots \ldots \ldots \$ 1.25 \$ 11.50$ 2 to $3 \mathrm{ft} \ldots \ldots \ldots \ldots \ldots \ldots \ldots+\$ 1.25 \$ 11.50$ 3 to 4 ft. Meianocarpa (nigra) 1.4013 .00 Black-fruited form of above. Each Per 10

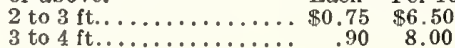

BACCHARIS-Groundsel Tree

B. Halimifolia. M.-A pretty shrub with dark green foliage; especially attractive in sutumn, with its fluffy white seed pods. Each Per 10 18 to 24 inch.......... \$0.75 \$5.00 2 to $3 \mathrm{ft} \ldots \ldots \ldots \ldots \ldots \ldots \ldots . \$ \ldots$

\section{BENZOIN-Spice Bush.}

B. aestivallis.-An attractive sbrub, valued for its bandsome flowers, which come before the leaves in early spring. The foliage turns bright yellow in autumn. Fruit scarlet and conspicuous.

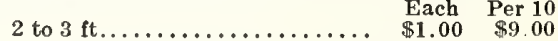

\section{BERBERIS-Barberry}

B. Thunbergii. D.-From Japan. A very pretty species of dwarf habit, small foliage, chang. able as an ornamental as well as bardy bedge. Eacb Per 10 Per 100 12 to 18 in . . . . . . . \$0.30 \$2.50 \$20.00

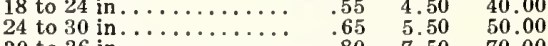
30 to 36 in .............. $80 \quad 7.50 \quad 70.00$ form of Berberis Thunbergii recently introduced. form of Berberis Thunbergii recently introduced. place of "Boxwood" where the Boxwood does not
thrive.

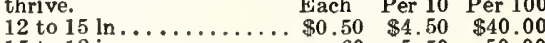

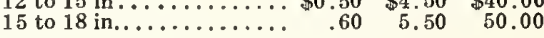




\section{Landscabe Views}
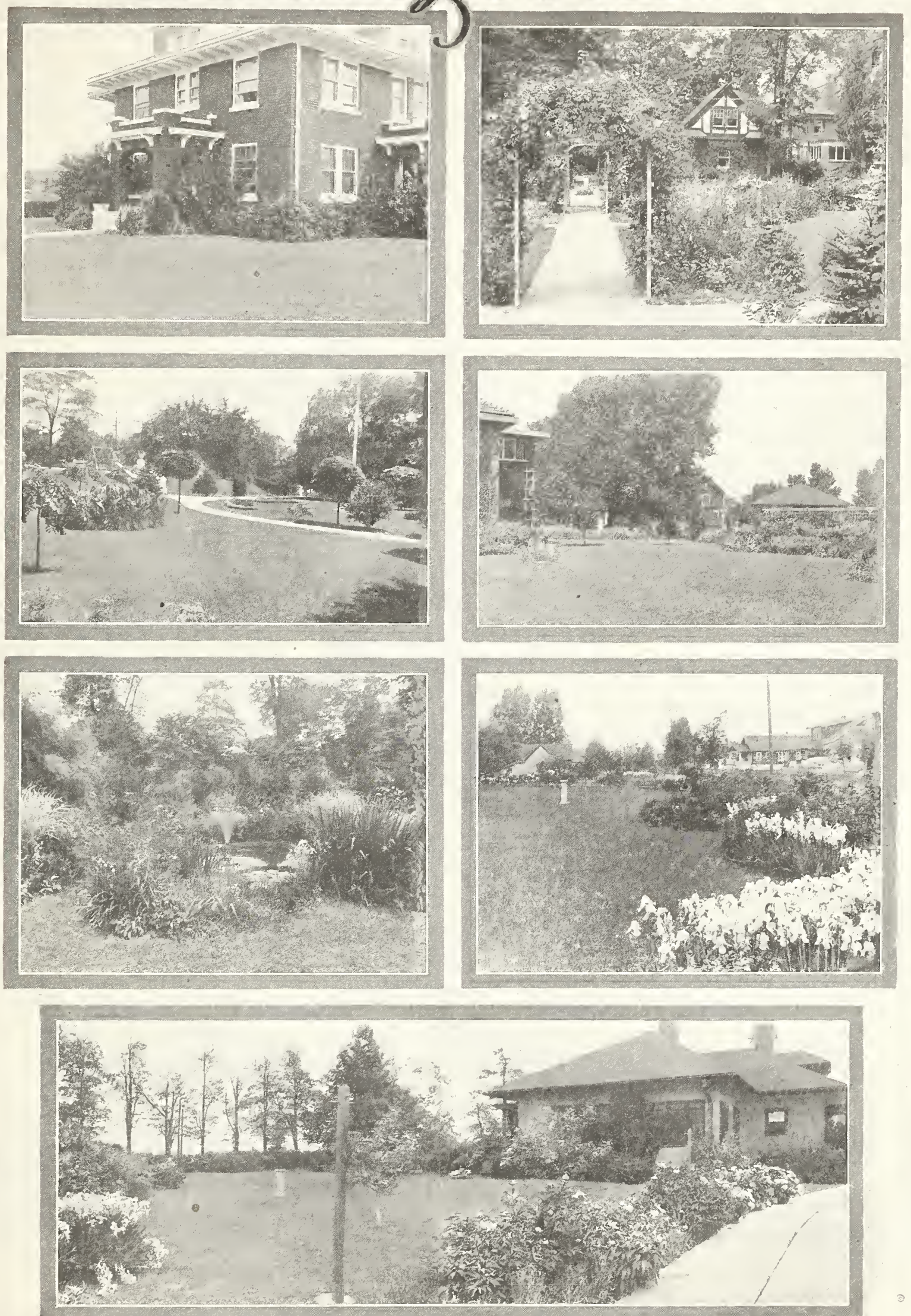


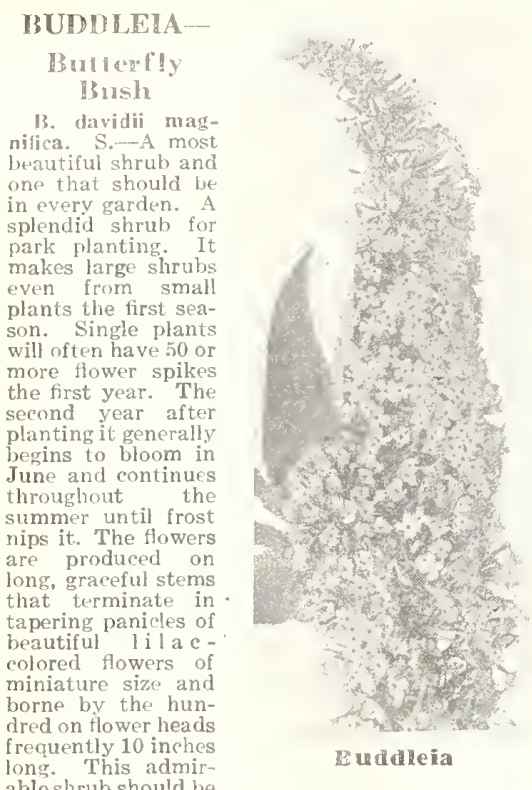

able shrub should be

classed as semi-herhaceous, as it sometimes freezes back to the ground in severe winters, but comes up again from the roots. A mulch of manure, leaves or other suitable material should be given before heavy freezing weather sets in. You should try some of these; you will be delighted with them.

2-year-old plants....... $\begin{gathered}\text { Each } \\ \$ 0.45\end{gathered} \quad \begin{aligned} \text { Per } 10 & \text { Per } 100 \\ \$ 3.75 & \$ 30.00\end{aligned}$

\section{CALLICARPA}

C. purpurea. D.-A pretty shrub with dense hairy foliage and showy flowers in small racemes.

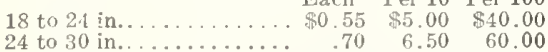

$\begin{array}{lrr}70 & 6.50 & 60.00\end{array}$

CALYCANTHUS-Carolina Allspice C. floridus. M.-A well-known native bush, hearing double, purple, fragrant flowers. 18 to 24 in........... $\$ 0.60$ Per 10 Per 100

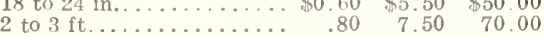

CARYOPTERIS (Bhe Spirea.)

C. incana (Mastacanthus) (Blue Spirea). D.A handsome, hardy perennial plant recently in. troduced from China. It is of a vigorous growth, producing flowers in great profusion the whole length of its branches, even young plants in small pots flowering freely. The color is of a rich lavender or sky blue. A valuable plant either for bedding or pot culture A 10 Per 100

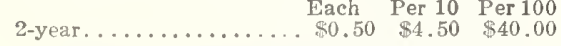

CEPHALANTHUS-Button Bush C. occidentalis. S. - A native shrub with globular heads of white flowers in July.

$\begin{array}{lrr}\text { Each } & \text { Per } 10 & \text { Per } 100 \\ \$ 0.60 & \$ 5.00 & \$ 40.00\end{array}$

2 to $3 \mathrm{ft}$. .

CLETIIRA-Sweet Pepper Bush

C. alnifolia. S.-A pretty little shrub that blossoms freely for several weeks in summer; blossoms freely for several weeks in summer; very fragrant white flowers, in s

an excellent honey plant for bees.
Each Per 10

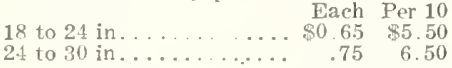

COLUTEA-Bladder Senna C. arborescens (Tree Colutea). L.-July. Foliage compound, of a pleasing green; fowers pea-shaped, yellow and brownish red, followed by showy, curiously inflated, reddish seed pods. This is the shrub which grows native on Mount
and the last one seen in ascending the crater.

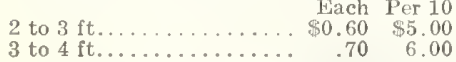

CORNUS-Cornel or Dogwood C. alba siberica (Siberian Red Dogwood). M.-A possible form of the Cornus Sanguinea, with intensely colored bark of the deepest crimson. Fine.
Each Per 10 Per 100 18 to 24 in.......... $\$ 0.35 \quad \$ 3.00 \quad \$ 25.00$

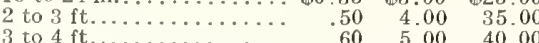
C. Alternifolia (Alternate leaved dogwood).Flowers creamy wlyte, in large bunches, very fragrant. Earh $\quad$ Per 10 3 to $4 \mathrm{ft}$. . . C. Amomum (sericea) (Silky Dogwood). S.Varies in height according to conditions, from 3 to 10 feet. Purplish hranches and black fruit in winter. Flowers in dense cymes, greenish white in early summer. 2 to $3 \mathrm{ft}$.
3 to $4 \mathrm{ft}$.

Each Per 10 Per 100 $\$ 0.50 \$ \$ 4.00 \$ 30.00$

C. var, elegantissima variegata D-One of the finest variegated shrubs; of rapid growth; the leaves are broadly margined with white, while some are entirely white. Bark bright red in winter.
2 to $3 \mathrm{ft}$., Each.................. $\$ 1.00$ C. mas. (Cornelian Cherry.) M.-April. A small tree or large shrub with showy yellow flowers in early spring, followed by deep scarlet fruit.

Each Per 10 Per 100

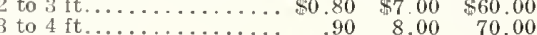
C. Paniculata (Gray Dogwood).-Ash-colored hark. Pointed leaves, greenish white flowers white fruit.

$\begin{array}{lr}\text { Each } & \text { Per } 10 \\ \$ 0.60 & \$ 5.00\end{array}$

2 to $3 \mathrm{ft} \ldots \ldots \ldots \ldots \ldots \ldots$ (Red Dogwood). $\$ 0.60 \$ 5.00 \ldots \ldots$ C. Sanguinea (Red Dogwood). M.-June white fruit; bark deep red and very attractive in winter. When planted with other shrubs, the winter. When planted with other shrubs, the effect in winter is very striking. As a single lawn
shrub it is well adapted, owing to its.low branching shrub it is well adapted, owing to its.low branching habit.

2 to $3 \mathrm{ft}$

Each Per 10 Per 100 3 to $4 \mathrm{ft}$ $\$ 0.50 \$ 4.00 \quad \$ 30.00$ C. stolonifera (Wild Red $\begin{array}{ccc}60 & 5.00 & 40.00\end{array}$ native species with smooth, slender branches, which are usually red in winter.

2 to $3 \mathrm{ft}$. . .

Each Per 10 Per 100

to $4 \mathrm{ft}$ $\$ 0.50 \quad \$ 4.00 \quad \$ 30.00$

C. stolonifera aurea (Yellow Branched Dogwood). M.-A very pretty shrub for winter color effect, bark bright yellow.

2 to $3 \mathrm{ft}$

$\begin{array}{lcc}\text { Each } & \text { Per } 10 & \text { Per } 100 \\ \$ 0.55 & \$ 4.50 & \$ 40.00\end{array}$ to $4 \mathrm{ft}$.

$\begin{array}{rrr}.65 & 5.50 & 45.00\end{array}$

\section{A Practical Hand-Book of Trees, Shrubs, Vines and \\ Herbaceous Perennials}

\section{By ${ }_{\text {Tohn Kirkegaard }}$}

This practical reference book gives valuable information regarding TREES, SHRUBS, PERENNIALS, EVERGREENS, ETC. Gives valuable planting instructions and plans for the beautification of grounds. Gives a dequate space to articles on insect pests, plants for certain purposes, planting, pruning, spraying and cultivation.

By SPECIAL ARRANGEMENT with the publishers we can now offer to our patrons copies of this valuable book for $\$ 2.00$, postage paid. Regular prices, postage paid, $\$ 2.71$

We offer this book as a premium to anyone purchasing fifty-dollars (\$50.00) worth or more of ornamental trees, shrubs, oines and perennials in one order, spring 1926. This offer does not apply on orders for fruit trees, small fruit plants, roses or greenhouse plants, insecticides and spray pumps or on special collections.
COR YLUS-Hazel or Filbert

C. americana (American Hazel). M.-The common American Hazel.

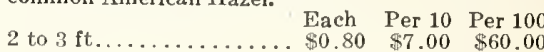

\section{CYDONIA-Japan Quinee or Fire}

C. Bush
japonica. M.-Flowers very abundant brilliant crimson scarlet. Fine for hedging.

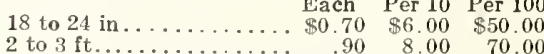

\section{DESMODIUM}

D. penduliflorum.-A low-growing shrub with rose-colored flowers in September. Dies to the ground in winter.

$\begin{array}{lll}\text { Each } & \text { Per } 10 & \text { Per } 100 \\ \$ 0.80 & \$ 7.50 & \$ 70.00\end{array}$

2-year plants.

\section{DEUTZIA}

Showy Japanese shrubs of the highest ornamental merit, and adapted to all good soils. Their clean foliage, upright, dense growth, free flowering nature, renders them especially valuable.

Prices unless ot herwise noted:

2 to $3 \mathrm{ft}$ $\begin{array}{lrr}\text { Each } & \text { Per } 10 & \text { Per } 100 \\ \$ 0.40 & \$ 3.50 & \$ 30.00\end{array}$ D. 4 ft............. $50 \quad 4.50 \quad 4000$ D. Scabra candidissima (Double White). M.ery pretty pure whit

D. scabra crenata. M.-The beautiful white single-flowered species that is a mass of bloom in une. Often preferred to the double sorts.

D. pride of Rochester. M.-A fine double variety, rather earlier than D. Crenata. Flower pink in bud, white when fully expanded.

D. rosea plena (Double Pink). M.-All the Deutzias are valuable and very profuse bloomer in the sixth month. This is one of the prettiest tall-growing varieties.

D. scabra. M. - A vigorous grower with rough, dull green foliage and clusters of showy double white bell-shaped flowers, in June and July.

D. s. Watereri. M.-A new white variety from England. with larger and more double flowers.

D. gracillis (Dwarf). D.-A low bush, three or four feet in diameter; flowers pure white and graceful. One of the prettiest and most popular small shrubs. Fine for winter forcing. Each Per 10 Per 100 12 to 15 in............ $\$ 0.50 \quad \$ 4.50 \quad \$ 40.00$

D. lemoineii." S.-A hybrid obtained by Mons. Lemoine, of France, by crossing the well-known Deutzia Gracillis with Deutzia Parviflora. Flowers pure white, borne on stout branches, which are of upright growth. Habit dwarf and free-flowering. A decided acquisition.

18 to 24 in. Each Per 10 Per 100 24 to $30 \mathrm{in.}$ $\begin{array}{rrr}\$ 0.70 & \$ 6.50 & \$ 60.00 \\ 90 & 8.50 & 80.00\end{array}$ DIERVILLA

D. Sessilifolia (Lu te a) S $S_{4}-\mathrm{L}$ o o s e clusters small yellow flowers in June. A good shrub foliage. Grows three to four feet high.

Each Per 10 Per 100

\section{Deigela}

DIERVILI

\section{ELEAGNUS} E. Angustifolia (Russian Olive). T.-A large
shrub, sometimes of tree form, with long, narrow, shrub, sometimes of tree form, with long, narrow, silvery green foliage.
followed by yellow fruit.

Each Per 10 Per 100

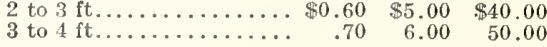

EUONYMUS-Strawberry or Spindle Tree

E. alatus (Cork-barked Euonymus). S.-Dwarf compact habit; wood very corky; leaves small; fruit red. Foliage turns bright red in fall. One of the very finest shrubs for autumn off

Each Per 10 Per 100 2 to $3 \mathrm{ft} \ldots \ldots \ldots \ldots \ldots \ldots \ldots 1.35 \$ 12.50$

E. Bungeanus. ' L.- - Very attractive on account of its rather large, yellowish fruit, which is borne profusely and remains so long upon the branches. profusely and remains so long upon the branches. 3 to $4 \mathrm{ft} \ldots \ldots \ldots \ldots \ldots . . \ldots 1.00 \quad$ Per 10

3 to $4 \mathrm{ft} . . . . . . . . . . . . \$ 1.00$. $\$ 8.50 \quad \cdots \ldots$ From Europe, and a favorite in old gardens; of good size, with rosy-red pods.

3 to $4 \mathrm{ft} . \ldots \ldots \ldots \ldots \ldots . \$ 1.00 \quad$ Each $\$ 8.50$ 4 to 5 ft............... $1.30 \quad 12.00 \quad \ldots \ldots$ 

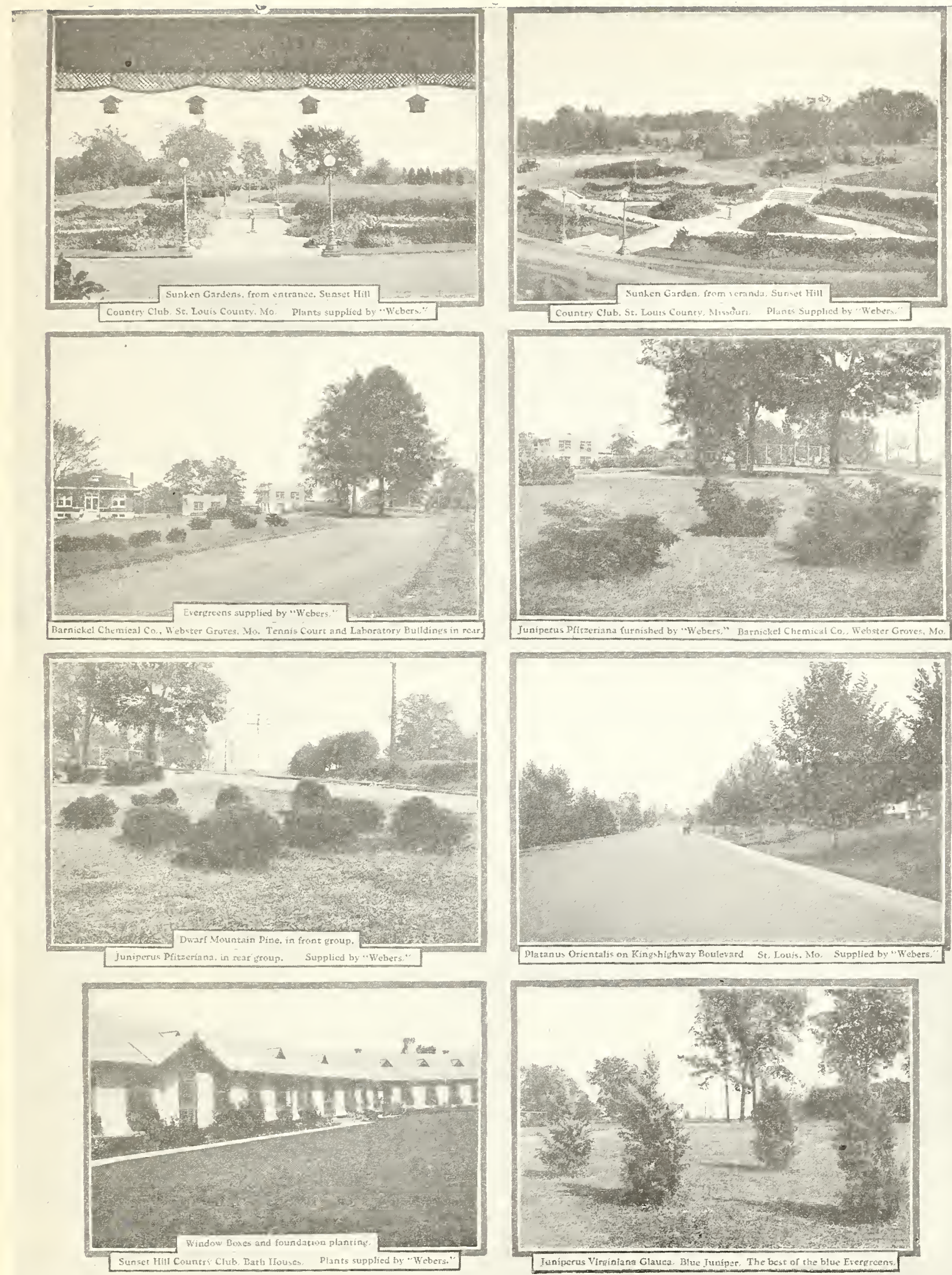

These are a few of the many places and homes which have been furnished by us. Your place can be made attractive by having us figure with you. Ask us about it. 


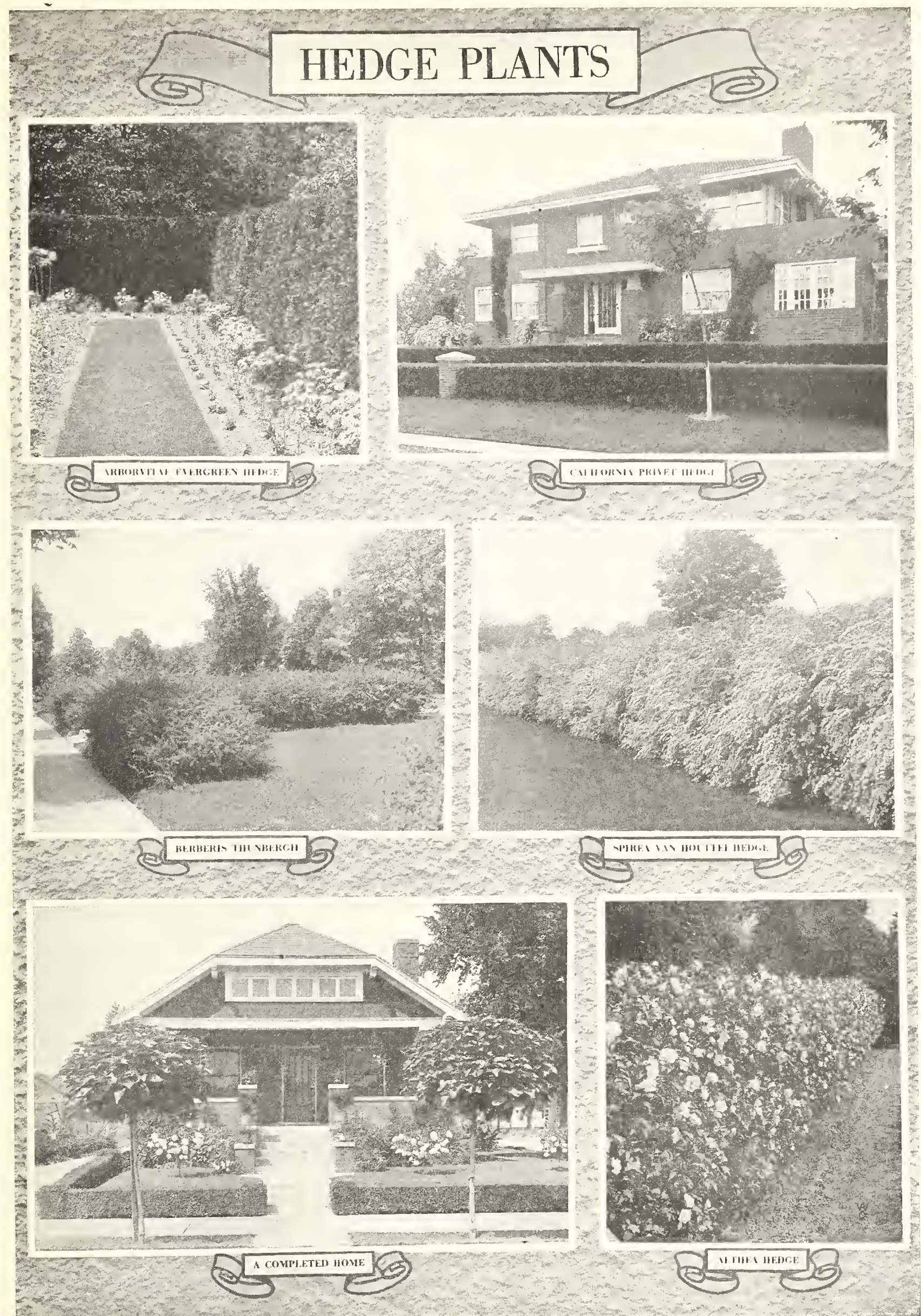


RHODOTYPOS-White Kerria

R. kerrioides. Lo $-\mathrm{A}$ choice and rare Japanese shrub, recently introduced. It is a slender brancbed bush, with very pretty, deeply veined leaves, and pure white flowers, borne at intervals all summer.

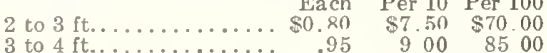

RHUS-Sumach

R. canadensis (aromatica) (Fragrant Sumach). S.-A native variety, exhaling a strong odor. Flowers greenish wbite; leaves lobed.

18 to 24 in.$\cdots \cdots$

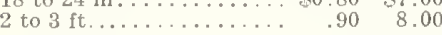

R. copallina (Dwarf Sumach). S.-Shining green foliage, changing to rich crimson in autumn; greenish yellow flowers in August.

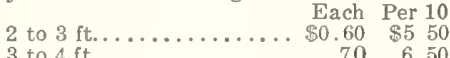

R. glabra (Smooth Sumach). L.-Very effective in autumn with its crimson seeds and foliage.

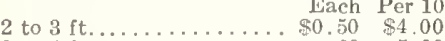

3 to $4 \mathrm{ft} . . . \ldots \ldots \ldots \ldots . .60 \% 5.00$

R. glabra laciniata (Cut-leaved). M.-A variety with deeply cut, fern-like foliage. An elegant plant for groups on the lawn. Each Per 10

15 to $18 \mathrm{in} \ldots \ldots \ldots \ldots . \$ 0.85 \quad \$ 7.00$

R. typhina (Staghorn Sumach). L. -A large shrub or tree, brilliant foliage and scarlet fruit in autumn.

$\begin{array}{lrr}\text { Each } & \text { Per } 10 & \text { Per } 100 \\ \$ 0.60 & \$ 5.00 & \$ 40.00\end{array}$

3 to $4 \mathrm{ft}$.

R. typhina laciniata (Staghorn Sumach). L.A large shrub or tree, brilliant foliage and scarlet fruit in autumn. A

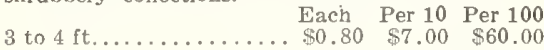

\section{RIBES-Currant}

Vigorous, remarkably bealthy plants of easiest culture. Besides this ornamental foliage and flowers, the fruit of several of the varieties is showy and very attractive. Valuable for grouping as a class or with other shrubs.

Each Per 10 Per 100 18 to 24 in . . . . . . . . $\$ 0.60 \$ 5.00 \quad \$ 40.00$

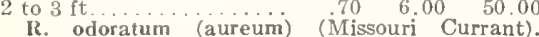
M.-May, Golden yellow, spicily fragrant flowers M.-May. Golden yellow, spicily fragrant flowers taking on showy autumnal coloring.

ROBENIA-Locust or Acacia

R. hispida (Rose or Moss Locust). M.-A native shrub of spreading, irregular growth. Flowers rosecolored in long clusters in June and at intervals through the summer.

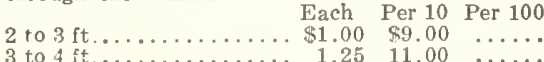

3 to 4 ft.

RUBUS-Bramble

R. odoratus (Flowering Raspberry). S.-Foliage large; flowers pretty rosy-purple. Eacb Per 10 Per 100 2 to $3 \mathrm{ft} \ldots \ldots \ldots \ldots \ldots . \$ 0.60 \quad \$ 5.00 \quad \$ 40.00$

\section{SAMBUCUS-Elder}

Rapid growing shrubs witb ornamental foliage, flowers and fruit. Will thrive in all soils, but give best fruiting results in that of a moist nature. Tbe Golden Elder is one of the finest golden-leaved shrubs, and is very useful. It shows its color best on a dry soil.

2 to $3 \mathrm{ft}$.

Each Per 10 Per 100 $\$ 0.60 \$ 5.50 \quad \$ 50.00$

3 to $4 \mathrm{ft} . . . \ldots \ldots \ldots \ldots . . . . .60 \quad 7.50 \quad 70.00$ S. canadensis (Common American Elder), L.-
Broad panicles of white flowers in June; reddish purple berries in autumn. A well-known native shrub.

S. canadensis aurea (Golden). L.-A beautifu golden-foliaged form. Very useful for foliage effect S. nigra (Black-berried Elder). L.-Of medium growth, with purplish-black berries in September. S. nigra laciniata (Cut-leaved). L.-Deeply cut foliage.

S. nigra variagata (Variegated). L.-Foliage beautifully variegated with silver and green. S. racemosous (Red-berried Elder). L.- White flowers in panicles in spring, followed by bright red berries.

\section{SPIREA-Meadow Swcet}

An indispensable class of small to medium-sized shrubs, embracing a wide range of foliage, habit of growth, color of flowers and season of blooming. All of easiest culture in all soils.

Prices on following varieties:

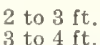
Each Per 10 Per 100 \begin{tabular}{rr}
65 & 5.50 \\
\hline & 45.00
\end{tabular}

S. Billardi. M.-Medium sized shrub, producing siked panicles of flowers, brigbt rose color.

S. Douglasii. M.-Immense terminal spikes of deep rose-colored flowers. One of the best

S. Fontenayii alba. M. - A pretty variety, with white flowers in summer. Upright grower.

S. opulifolia. (See Physocarpus.)
S. salicifolia (Willow-leaved). M

row, pointed leaves, and rose-colored fong, narJune and July.

S. Van Houtte. M.-The grandest of all the Spireas. It is a beautiful ornament for tbe lawn at any season, but when in flower it is a complete fountain of white bloom, the foliage hardly showing. Clusters of twenty to thirty flat, white florets make up the racemes, and these clusters are set close along tbe drooping .stems. Perfectly bardy and an early bloomer.

Special varicties quoted below:

S. Bumalda. S.-A spreading, low bush, with dark leaves brightened by corymbs of pretty, light pink flowers in May, and at intervals all summer.

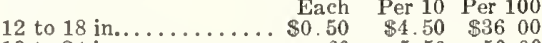

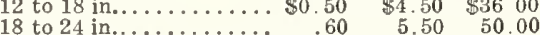
S. bumalda Anthony Waterer. D.-A new crimson-flowered variety; one of the most beautiful of dwarf flowering shrubs. It makes a low, com pact busb, 15 to 18 inches bigh, and is covered nearly the whole growing season with large umbels of deep crimson flowers. Perfectly hardy, it makes a fine. compact plant for low clumps or for bedding purposes. Grown as a or house decorations.

$\begin{array}{lrr}\text { Each } & \text { Per } 10 & \text { Per } 100 \\ \$ 0.50 & \$ 4.50 & \$ 36.00\end{array}$

12 to 18 in

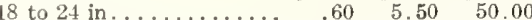

S. Callosa var. Froebelli. D.-Flowers bright rosy-red, in flat umbels. This is one of our finest Spireas, excellent as a border shrub. Foliage
turns purple in the fall. Branches willowy. Should be in every garden.

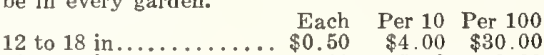
18 to 24 in................. $.60 \quad \$ 0.50 \quad \$ 4.00 \quad \$ 00.00$

S. callosa alba. D. -Of compact growth, with upright branches, crowded witb large, flat clusters of white flowers nearly all summer.

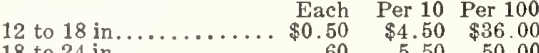
18 to 24 in............... Flowers deep rose-red. A S. collosa superba. Flowers deep rose-red. A
fine garden variety.

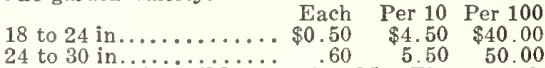
24 to 30 in................... 50 . 50 . 50.00 pink. A plant of free growth, wbicb should be allowed plenty of room to develop; it carries a great quantity of bloom.

Each Per 10 Per 100 18 to 24 in ............. \$0.55 $\$ 500 \$ 45.00$ S. Multiflora arguta. S.- Of dwarf habit Spirea. Early May.

$\begin{array}{lll}\text { Eacb } & \text { Per 10 } & \text { Per } 100 \\ \$ 0.60 & \$ 5.00 & \$ 40.00\end{array}$

18 to 24 in

24 to 30 in $\begin{array}{lll}.70 & 6.00 & 50.00\end{array}$

30 to 36 in ................. with numerous S. prunifolia. M. - Very distinct, with numerous
small, double white flowers, blooming early.

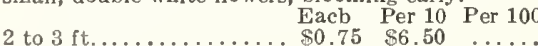
2 to $3 \mathrm{ft}$.

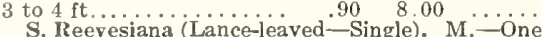
of the most ornamental; sbowy flowers, pure white in umbels and very numerous.

18 to 24 in Eacb Per 10 Per 100

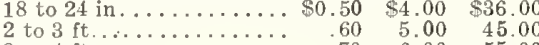
3 to $4 \mathrm{ft}$................ 70 . $6.00 \quad 55.00$ Dounle). M.-A perfect gem, eacb individual flowe as double as a Ranunculus and very conspicuous.

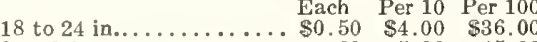
2 to $3 \mathrm{ft} . . . . \ldots \ldots \ldots \ldots . . .60 \quad 5.00 \quad 45.00$

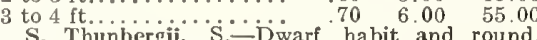
raceful form: branches slender and somewhat groceping: foliage narrow and yellowisb-green Flower small white. Early bloomer.

18 to 24 in............. Each $\$ 0.60$ Per 10 Per 100

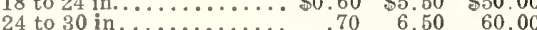

\section{STEPHANANDRA}

S. flexuosa $D$, - A beautiful low shrub witb very ornamental deep green, dense foliage. Branches spreading and drooping. Flowers insignificant, in small termina! panicles. Freezes back during the winter.

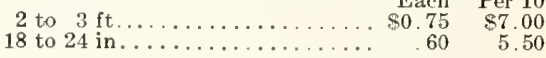

$\begin{array}{rr}\text { Each } & \text { Per } 10 \\ \$ 0.75 & \$ 7.00\end{array}$

\section{SYMPIIORICARPUS-St. Peter's}

\section{Wort}

S. racemosus (Snowberry). S.-Flowers inconspicuous, rose-colored in June and July; leaves thin, dark green; fruits large, milk-wbite, clustered persistent until late in winter.

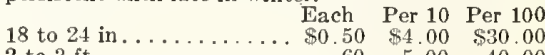
2 to $3 \mathrm{ft} \ldots \ldots \ldots \ldots \ldots \ldots, \quad .60 \quad 5.00 \quad 40.00$

\section{SYRINGA-Lilac}

S. japonica. M.-A species from Japan, be coming a good-Eized tree, Foliage dark green. glossy; leathery; flowers creamy white, odorless. in great panicles. A month later than other in great

2 to $3 \mathrm{ft} \ldots \ldots \ldots \ldots \ldots . \quad$ Each $\quad$ Per 10

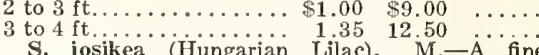

S. josikea (Hungarian Lilac). M.-A fine distinct species of tree-like growth, with dark shining leaves and purple flowers in June, after the
other Lilacs have done blooming. Esteemed for its other Lilacs have done
fine habit and foliage.

2 to $3 \mathrm{ft}$ Eacb Per 10 3 to $4 \mathrm{ft} \ldots \ldots \ldots \ldots \ldots \ldots \ldots \ldots+\$ 1.00 \quad \$ 9.00$ S. rothomagensis (chinensis) (Rouen Lilac) M.-A distinct hybrid variety, with reddish flowers; panicles of great size and very abundant. 2 to $3 \mathrm{ft} . \ldots \ldots \ldots \ldots \ldots . \ldots{ }_{\$ 0.90}^{\text {Each }} \underset{\$ 8.50}{\operatorname{Per} 10}$

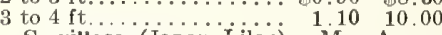

S. villosa (Japan Lilac). M.-A species from purple in bud, white when open, fragrant light cially valuable for late flowering. Single.

2 to $3 \mathrm{ft} \ldots \ldots \ldots \ldots \ldots \ldots{ }_{\$ 1.00}^{\text {Each }} \underset{\$ 9.00}{\mathrm{Per}}$ 3 to $4 \mathrm{ft} \ldots \ldots \ldots \ldots \ldots \ldots \ldots \ldots+1.00 \quad \$ 9.00$

S. vulgaris (Common Purple Lilac). M. Large shrub with larger leaves and flowers than Large shrub with larger leaves and flowers than
above. Flowers bluish purple.

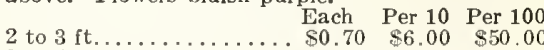
2 to $3 \mathrm{ft} \ldots \ldots \ldots \ldots \ldots \ldots \ldots$
3 to $4 \mathrm{ft} \ldots \ldots \ldots \ldots$ S. vulgaris alba (Common White Lilac). M.Flowers in slender panicles, pure white and fragrant.

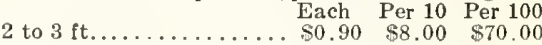

NAMED VARIETIES OF LILACS

This class of litacs is very scarce this season therefore only offering these in limited quantity.

\section{SYRINGA-Single and Double} Varieties

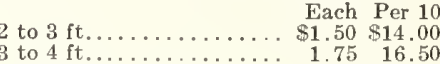

Atphonse Lavalle.-Beautiful blue, sbading violet.

Double.

Congo--Deep red purplish single flowers.

Belle de Nancy.-Great panicles of satiny rose, almost white center. Double

Marie Legrave.-Single white flowers in large anicles.

Michael Buchner-Double flowers of pale lilac.

Mine. Abel Chatenay.-Double pure white flowers in large panicles

Negro.-Very dark violet-purple single flowers President Carnot.-Pale blue double flowers with white in center.

President Grevy.-Beautiful blue flowers in huge panicles.

Souvenir de Ludwig Spaeth.-Single dark purplisb-blue flowers in long panicles.

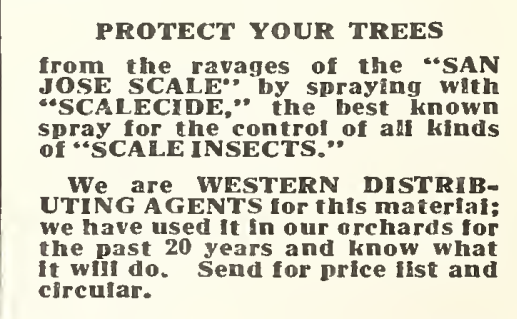


)

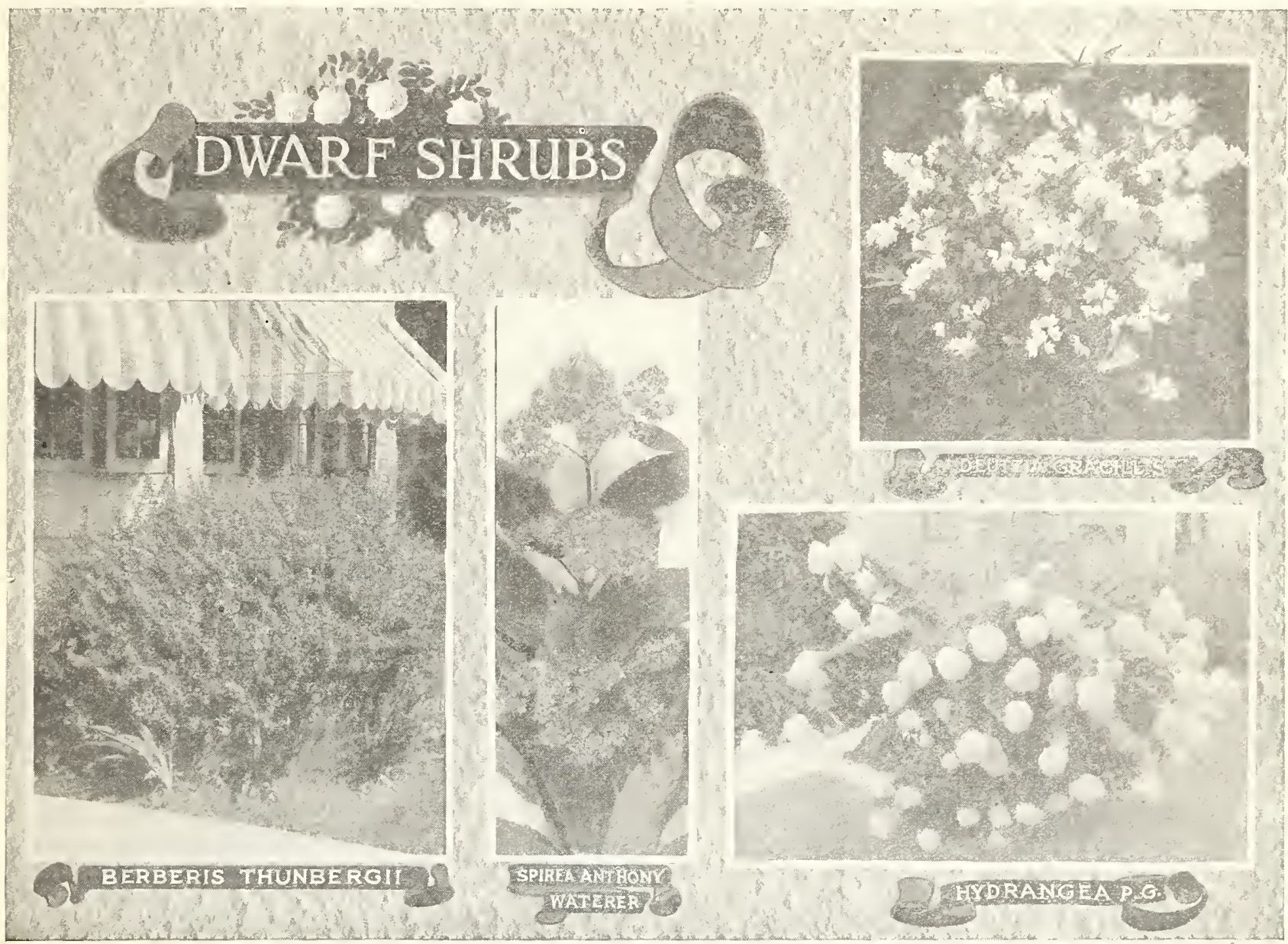

TAMARIX-Tamarisk

The Tamarisks are hardy shrubs, of strong growth. foliage light and feathery, their flowers delicate and fringing. usually in some light shade of red or pink. Will grow anywhere.

Prices, unless otherwise noted:

Each Per 10 Per 100

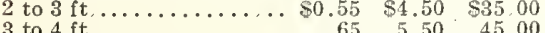

T. odessana (Caspian Tamarisk). A new T. odessana (Caspian Tamarisk) A new
variety with pale rose flowers, blooming earlier variety with
than Gallica.

T. tetranda purpurea. L.-Of dwarfer and more dense growth than T. Africana. Purplish-pink flowers in mid-summer.

$\mathrm{T}$ africana. L.-A tall, graceful shrub with small foliage like a Juniper, and delicate small rosypurple flowers, produced in spikes; very pretty.

T. gallica. L.-Delicate pink or white flowers in slender panicled racemes; leaves bluish-green. An exceedingly pretty species.

T. hispida estivalis. L.-A new variety, raised from T. Hispida. More vigorous and not so compact. In July the branches are covered on the half of their length with numerous inflorescences of large flowers of a nice bright carmine. Foliage silvery.

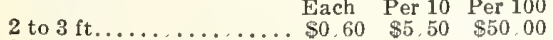

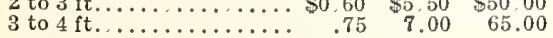

If In need of a Spray Pump send for catalogue and price list. We are distrlbuting agents for the Deming Company.

\section{VIBURNUM-Snowball}

V. dentatum (Arrow-wood). M.-A fine shrub for massing for foliage effect. Flowers greenish white.

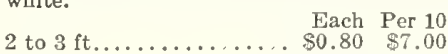

$\begin{array}{rrr}2 \text { to } 3 \mathrm{ft} \ldots \ldots \ldots \ldots \ldots \ldots \ldots & \$ 0.80 & \$ 7.00 \\ 3 \text { to } 4 \mathrm{ft} . \ldots \ldots \ldots \ldots & .90 & 8.00\end{array}$

v. lantana. L.-A large, robust shrub, with V. lantana. L.-A large, robust shrub, with
soft, heavy leaves and large clusters of white soft, heavy leaves and large clusters of white flowers in May, succ
foliage very late.

Each Per 10 Per 100

V. Opulus (High Bush Cranberry). L.-Very ornamental. Berries resembling small cranberries, hang until destroyed by frost late in fall.

Each Per 10 Per 100 2 to $3 \mathrm{ft} \ldots \ldots \ldots . \$ 0.80 \quad \$ 7.00 \quad \$ 6000$

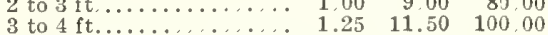

v. Opulus sterile (Common Snowball). L.An old and well-known shrub, bearing large balls of pure white flowers.

Each Per 10 Per 100

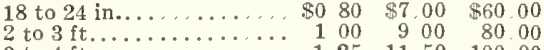

$\$ 080 \$ 7.00 \$ 6000$

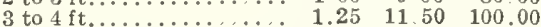

V. tomentosum. M. - The single form of V. Plicatum; flowers pure white, borne along the branches in lat cymes, in the greatest profusion early in June. Perfectly hardy, vigorous and free blooming. Desirable.

Each Per 10 Per 100 2 to $3 \mathrm{ft} . \ldots \ldots \ldots \ldots \ldots \ldots \$ \$ .90 \quad \$ 8.50 \quad \$ 80.00$ 3 to 4 ft................. 1.10 10.00 90.00 $\begin{array}{ll}\text { V. tomentosum plicatum (Japan). } & \text { M.-A } \\ \text { rare and exceedingly beautíful species of Japan; }\end{array}$ hanging long on the bush; a very choice and dehirable shrub.

18 to 24 in.......... $\$ 0.95$ Each $\begin{aligned} & \text { Per } 10 \\ & \$ 8.50\end{aligned}$

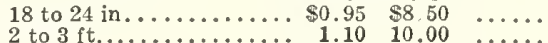

VITEX-Chastise Tree

Vitex Agnus Castus,-A graceful shrub, growing rom 5 to 6 feet high, with dense spikes 6 to 8 nches long, of lilac-colored flowers late in summer. V. Agnus Castus Alba.-Bame in growth, but has white flowers.

$$
2 \text { to } 3 \mathrm{ft} \ldots \ldots \ldots \ldots \ldots, \$ 0.60 \quad \begin{array}{r}
\text { Each } \\
\$ 5.00
\end{array}
$$

\section{WEIGELIA-Diervilla}

Beautiful shrubs that bloom in June and July. The flowers are produced in so great profusion as almost entirely to hide the foliage. They are very desirable for the horder or for grouping. and also as specimen plants for the lawn.

Prices, unless otherwise noted:

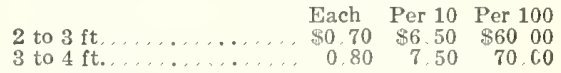

W. Hendersonii-DDark pink, strong grower.

W. nana variegata. S.-An exceedingly pretty variety, the variegation being very distinct.

W. van houttel. M.-A good grower, with clear carmine lowers.

W. Abel Carriere. M.-Bright rose. One of the best.

W. Candida. M-Flowers pure white and produced in great profusion in June and continue to bloom at intervals through the summer.

W. Desboísí. M.-Deep rose colored flowers.

W. Rosea. M.-Flowers bríght rose. Very popular.

W. Eva Rathke. M.-Flowers brilliant crimson, a beautiful distinct, clear shade. Very scarce.

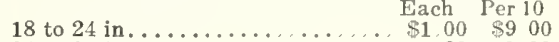
24 to $30 \mathrm{in} \ldots \ldots \ldots \ldots \ldots \ldots \ldots \ldots \ldots, 1,20 \quad 10.00$

W. Floribunda. M.-Flowers dark red, A profuse bloomer.

2 to $3 \mathrm{ft} . \ldots 1$ Each Per 10 2 to $3 \mathrm{ft} \ldots \ldots \ldots \ldots \ldots \ldots \ldots \ldots \ldots . \$ 1.00 \quad \$ 9.00$ 


\section{Ornamental Vines and Climbers}

\section{AKEBLA}

A. qulnata.-A beautiful, hardy Japanese vine, with unique foliage and cbocolate purple flowers of delightful fragrance, in large clusters.

2-year-old plants.............. $\$ 0.70 \quad \begin{array}{r}\text { Fach } \\ \$ 6.00\end{array}$

\section{AMPELOPSIS} A. quinquefolia Engelmanni (Engelmanni Ivy).--
Shorter jointed than Quinquefolia. A good Shorter jointed than Quinquefolia.
climber; grows 6 to 10 feet in a season.

Each Per 10 Per 100 2-year-old plants........ \$0.45 $\$ 3.50 \quad \$ 25.00$ A. quinquefolla (American Ivy or Virginia Creeper).-Has beautiful digitate leaves that become rich crimson in autumn; a very rapid grower. One of the finest vines for covering walls, verandas One of the finest
or trunks of trees.

Each Per 10 Per 100 2-year-old plants......... $\$ 0.45 \quad \begin{array}{lll}\text { Each } & \text { Per } 10 & \text { Per } 100 \\ \$ 3.50 & \$ 25.00\end{array}$ A. tricuspidata Veitehi (Boston Ivy).-Of Japanese origin; entirely hardy, with foliage turning brilliant red in autumn. It clings tightly to walls, and is unsurpassed as a basket or vase 2-year-old plants....... $\$ 1.00 \quad \$ 9.00 \quad \$ 80.00$

\section{BIGNONIA-Trumpet Vine}

B. radicans (American Climbing Trumpet Vine) A splendid, hardy climbing plant, with large A splendid, hardy climbing plant, wit

trumpet-shaped scarlet flowers in August. 2-yr.-old plants......... $\$ 0.50 \quad \begin{array}{rrr}\text { Each } & \text { Per } 10 & \text { Per } 100 \\ \$ 4.00 & \$ 30.00\end{array}$

CEIASTRUS-Bitter Sweet

C. scandens.-A native climber, with handsome, glossy foliage and large clusters of beautiful orange-crimson fruits, retaining all winter-Very bright in effect and charming for winter decorations. 2-yr.-old plants........ \$0.50 $\$ 4.00$ \$30.00

\section{CLEMATIS}

A beautiful class of hardy climbers, excellent for pillars or trellises. They delight in a rich soil and sunny situations. and are perfectly hardy. c. coccinea.-A native Southern species, quite hardy, flowers small, bright scarlet; a very interhardy, flower

2-yr.-old plants......... $\begin{array}{r}\text { Each } \\ \$ 0.50\end{array} \begin{array}{r}\text { Per } 10 \\ \$ 4.50\end{array}$ Per 100

C. Henryil.-A magnificent, large white flower a free grower and bloomer.

2-yr.-old plants. Each Per 10 Per 100 2-yr.-old plants, potted... $1.25 \quad \ldots \ldots \ldots$

C. Jackmannii-—Deep violet purple, with a rich, velvety appearance. One of the best.

Each Per 10 Per 100

2-yr.-old plants......... \$1.25 $\$ 11.00 \quad \ldots \ldots$

2-yr.-old plants, potted... C. paniculata.-A vine of very rapid growth, some, clean, glossy green foliage. The flower are of medium size, pure white, borne in immense sheets, and of a most delicious and penetrating fragrance.

2-year-old plants....... Each Per 10 Per 100

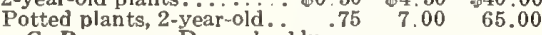
C. Ramona.-Deep sky-blue.

Each Per 10 Per 100

2-year-old plants........ \$1.25 $\$ 11.00 \quad \ldots$.

See Pueraria Thunbergiana.

EUONYMUS

E. Kewensis.-New variety, small dark green foliage. A fine rock plant or ground cover. Grows close to the ground, fine under trees where grass will not grow.

4-in. pot plants... Each Per 10 Per 100

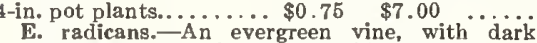
green foliage; will cling to walls like ivy. Each Per 10 Per 100 $\begin{array}{lll}\text { 4-in. pot plants, strong... } \$ 0.60 & 5.50\end{array}$...... E. radicans variegata. - An evergreen vine with
variegated foliage that clings to walls like ivy. Each Per 10 Per 100 4-in. pot plants, strong... \$0.60 \$5.50 $\ldots .$.

E. Radicans vegeta.-A strong growing variety with larger leaves than the type, and producing plant the greater part of the winter. As an evergreen, absolutely hardy wall cover this plant is unequaled. An enthusiastic horticultural writer predicts tbat it will become as popular for tbis purpose here as the Ivy is in England.

Each Per 10 Strong plants in pots...........\$0.75 $\$$ \$6.50

\section{HEDERA-Ivy} The Ivies are evergreens and frequently suffer
from exposure to the bright sunlight in winter. For this reason the north side of a wall or building For this reason the north side of a
is a better situation than the south.

H. helix (English Ivy).-A familiar evergreen vine, dark green leaves, favors shady location. The young wood sometimes winter-kills in this climate, due to the action of the sun more than the cold. Suitable to cover buildings, rocks, trellis work, graves, and as a carpet under trees in places where grass will not grow.

$\begin{array}{rrrr} & \text { Each } & \text { Per } 10 & \text { Per } 100 \\ 3 \text {-in pots, strong plants... } & \$ 0.35 & \$ 3.00 & \$ 25.06 \\ 4 \text {-in. pots, extra plants.... } & .50 & 4.50 & 35.00\end{array}$
$\begin{array}{rrrr}4 \text {-in. pots, extra plants.... } & .50 & 4.50 & 35.00 \\ 5 \text {-in. pots, extra plants.... } & .60 & 5.50 & \ldots . .\end{array}$

\section{LONICERA-Ioneysuckle}

L. Japonica aurea reticulata.-A variety with beautifully variegated foliage; leaves netted and veined with clear yellow; flowers yellow and veined fragrant. L. Japonica Halleana.-Color white, changing
to yellow, very fragrant, blooms from June to November.

L. periclymenum Belgica (Monthly Fragrant). A fine, rapid growing variety; flowers large and very fragrant; color red and yellow; a constant bloomer.

L. scmpervirens (Scarlet Trumpet).-A strong, rapid elimber; blooms very freely the entire season; bright red, trumpet-shaped flowers.

Each Per 10 Per 100

2-year-old, strong plants... $\$ 0.50 \quad \$ 4.00 \quad \$ 30.00$

\section{LYCIUM-Matrimony Vine}

L. Chinensis--Very hardy, grows anywhere. The slender, drooping branches are somewhat thorny and bear grayish green leaves. Flowers small, pink and purple, from June to September, and are then succeeded by a profusion of bright scarlet and orange fruits through late fall and winter. A good plant for covering trellis work and bowers; also for covering bare places of rock. Each Per 10 Per 100 2 to $3 \mathrm{ft} . \ldots \ldots \ldots \ldots \ldots . \$ 0.45 \quad \$ 3.50 \quad \$ 30.00$

\section{PERIPLOCA-Silk Vine}

P. graeca.-A beautiful, rapid growing climber. Fine to twine around an old tree or other support; will grow 30 to 40 feet in height. Flowers
purple, brown, in auxiliary clusters. Foliage glossy.

Per 10

2-year-old plants.

$\$ 0.60 \$ 5.50$

\section{POLYGONUM AUBERTI-Silver}

\section{Lace Vine}

One of the most desirable flowering climbers. The plant is of strong, vigorous growth, attainin a height of 25 feet or more, producing through th summer and fall great foamy sprays of whit flowers, and a well established plant during its long flowering period is a mass of bloom.

Each Per 10 Strong plants.............. \$1.00 $\$ 9.00$ Extra size................... $1.25 \ldots .$.

\section{PUERARIA THUNBERgIANA-Kudzu} Vine (Dolichos)

P. thunbergiana.-Tbis is witbout a doubt the fastest growing vine we know of; we have grown and recommend same to our customers wanting a fast-growing vine for covering arbors and trellises, also for covering rocky slopes.

1-year-old plants. $\$ 0.50$ Per 10

\section{WISTARIA}

The Wistaria is one of the most decorative of vines, and for porch decoration without too much shade it has no superior. Tbe long, twining branches bear great sprays of foliage, while its charming flowers sway with every passing breeze. W. Sinensis (Chinese).-Flowers in clusters. pale blue, sometimes gives a second crop of flowers
in the fall.

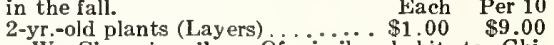
W. Sinensis alba.-Of similar habit to Chinensis, with pure white flowers. Each Per 10 2 -yr.old plants (Layers) .......... $\$ 1.00$ from layers or grafts
Our Wistaria .are grown Our Wistaria are grown from layers or grafts
from blooming plants, hence are guaranteed to from

\section{Evergreen Shrubs}

Evergreen shrubs are coming into use more and more, as they are so desirable in landscape work. The foliage helps out and enlivens the barenes of deciduous trees and shrubs in winter. They are all fond of shady places and are suitable for north sides of houses, garages and north hillsides. The soil for this class of shrubs should be care fully prepared with leaf mold, peaty soil. and should be mulched annually with well decom posed manure or partly decomposed forest leaves.

Spring is the proper time to transplant.

\section{AZALEA AMOENA}

A bushy, dwarf grower with small green leaves that deepen to a lustrous coppery hue in winter.
In April or May the whole plant is covered with In April or May the whole plant is covered with a mass of brilliant, claret-colored flowers that retain their beauty for several weeks. Very ornawalks or for bordering beds of Kalmia, Ilex, etc.

10 to 12 in ................. $\underset{\$ 2.50}{\text { Each }}$ 12 to 15 in.................................. ${ }_{3.00}$

\section{ILFX-Holly}

The Hollies are coming into demand as people get to know what splendid ornamental plants they are. The foliage is always beautiful, the flowers interesting and the fruits ornamental.
group of Hollies is always a source of pleasure.

I. opaca (American Holly).-This is our native Holly, but if a rare plant in our American nurseries.

2 to $3 \mathrm{ft} . \mathrm{B}-\mathrm{B}$.
3 to $4 \mathrm{ft} . \mathrm{B}-\mathrm{B}$. Each $\$ 3.50$ $\$ 3.50$
5.00

\section{Verticillata.-See Deciduous Shrubs.}

\section{MATIONIA}

Mahonia aquifolia (Holly-Leaved Mahonia).A native species of medium size, with purplish. shiny, prickly leaves, and showy, bright yellow flowers in May, succeeded by bluish berries. Its glossy foliage and neat habit render it a very popular plant for decorative purposes.

$\underset{\$ 2.50}{\text { Each }}$ 18 to 24 in. B-B............... \$2.50 24 to 30 in. B-B.............. 4.00

Plant Flowers to beautify your home grounds, to hide unsightly foundations, in borders or hedge, or in artistically arranged beds, to make your grounds radiate with their beauty and fragrance.

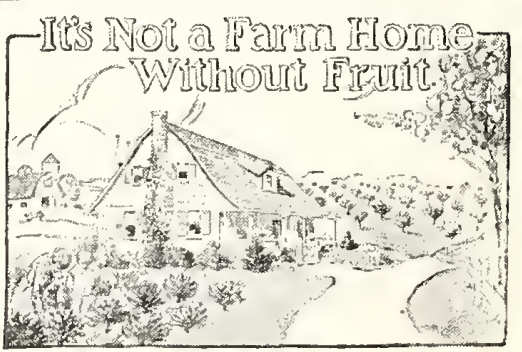




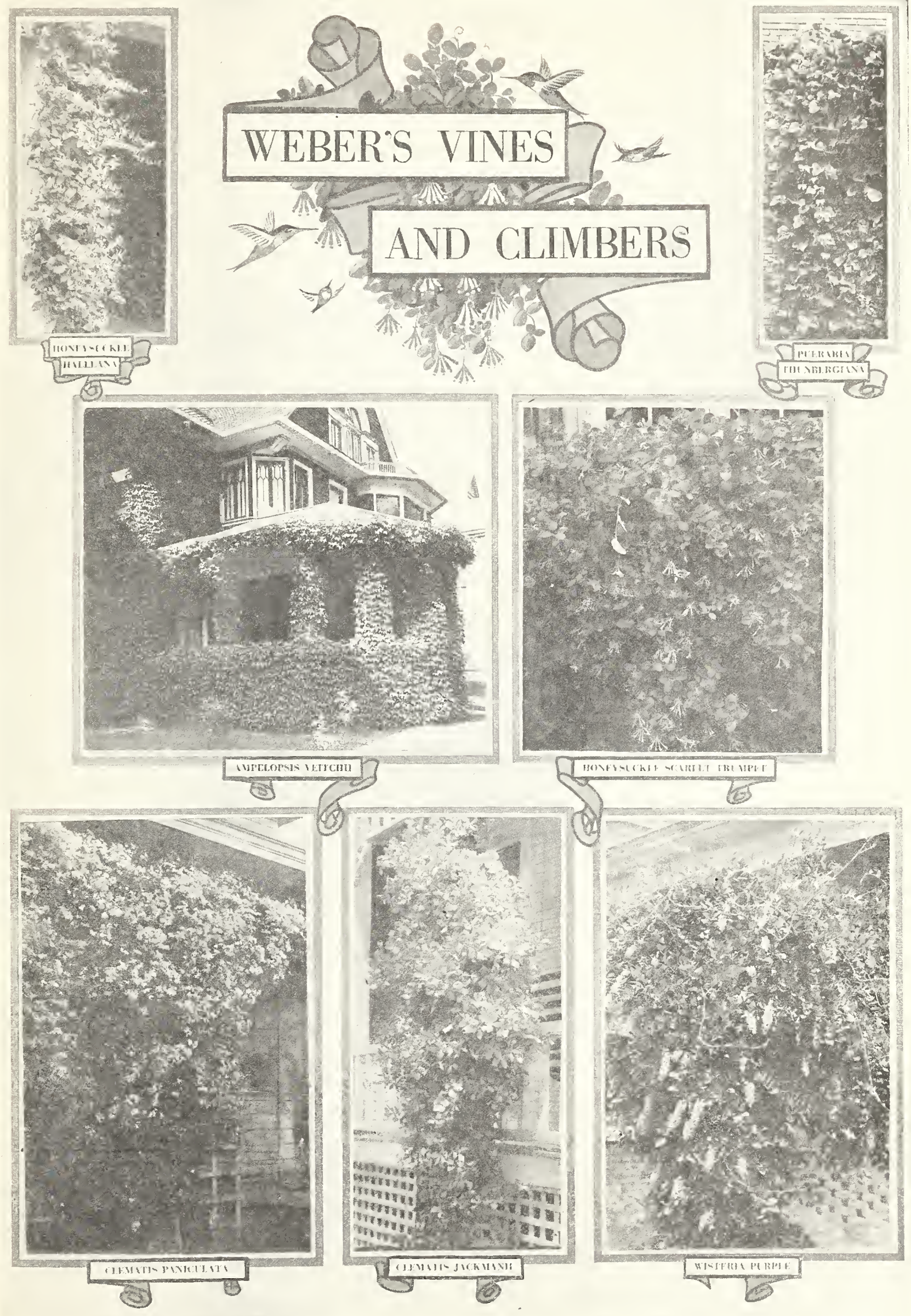




\section{Evergreens-Coniferae}

Our trees have all been transplanted two or three times, are handsome, selected trees, well branched and rooted, suitable for lawns, etc.

Evergreens can be most successfully transplanted a short time before they are ready to start into growth in the spring. They can also be planted safely very early in the fall. All Evergreens are dug the "Weber Way" with Ball and Burlap.

\section{ABIES-Fir}

A. Canadensis (Hemlock).-See Tsuga.

A. Douglassii.-See "Pseudotsuga."

BIOTA-Oriental Arborvitae.

B. orientalis aurea nana (Berkman's Golden Arborvitae). The most popular Biota grown. This conifer is of dwarf, compact and symmetrical habit. A perfect gem for small gardens, cemetery lots or formal planting. For window boxes and vases this variety is most effective.

12 to $15 \mathrm{in}$

Each Per 10

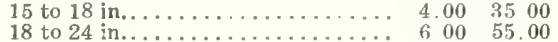

24 to 30 in.

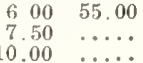

T. orientalis (common Chinese Arborvitae), - A tall fast growing tree but not so compact.

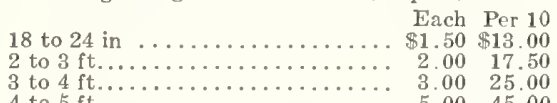

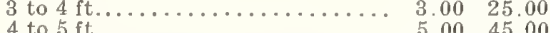

B. Orientalis Compacta.-A compact form of Chinese Arborvitae. Foliage very dark green. Fine where a slow-growing, compact tree is desired.

24 to 30 in.............. $\begin{array}{r}\text { Each } \\ \text { Per } 10\end{array}$

B. Orientalis Pyramidalis (Chinese pyramidal Arborvitae).- A fine pyramidal tree, dark green foliage, fine for foundation planting and for tub purposes.

6 to $7 \mathrm{ft}$

5 to $6 \mathrm{ft}$

4 to $5 \mathrm{ft}$...... $\begin{array}{rr}\text { Each } & \text { Per } 10 \\ \$ 12.00 & \$ 111.00 \\ 10.00 & 90.00 \\ 8.00 & 75.00\end{array}$

T. orientalis pyramidalis (Baker's Strain).Pyramidal growth, densely clothed with fresh, lively green foliage; very hardy; one of the best.

\begin{tabular}{|c|c|c|}
\hline $\begin{array}{l}30 \text { to } 36 \text { in... } \\
36 \text { to } 42 \text { in.. } \\
42 \text { to } 48 \text { in.. }\end{array}$ & $\begin{array}{r}\text { Each } \\
\$ 5.25 \\
6.00 \\
7.50 \\
10.50\end{array}$ & $\begin{array}{r}\text { Per } 10 \\
\$ 50.00 \\
55.00 \\
70.00 \\
100.00\end{array}$ \\
\hline
\end{tabular}

B. Ronita (Blue form). $-A$ beautiful form of the Oriental Arborvitae, evidently a cross between Retinospora and the Biota varieties. Color of foliage a beautiful bluish-green.

24 to 30 in.

30 to 36 in.

Each Per 10 $\$ 4.25 \$ 40.00$ 36 to 42 in ................ $6.00 \quad 55.00$

\section{JUNIPERUS - Juniper or Cedar} J. chinensis Pfitzeriana (Pfitzer's Junipor).the color of foliage a bright silvery green; perfectly hardy.

18 to 24 in.

Each Per 10

24 to 30 in.

$\$ 5.50 \$ 50.00$

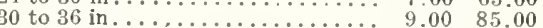

J. communis hibernica (Irish Juniper). -One of the most popular Junipers known. Rigidly upright and formal in character, resembling a green column.

Each Per 10
$\$ 3.50 \$ 30.00$

2 to $3 \mathrm{ft}$. specimens.

J. Stricta.-A very compact little evergreen of pyramidal habit. Foliage dark green. A beautiful evergreen for vases or where a slow-growing dwarf evergreen is desired. 15 to 18 in............... $\$ 3.00 \quad \begin{aligned} & \text { Pach } 10 \\ & \$ 25.00\end{aligned}$ 18 to 24 in................... $4.00 \quad 35.00$

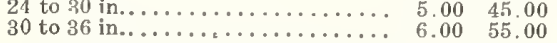

J. Virginiana Cannarti (Cannarti Juniper).-Of pyramidal habit, branches graceful, of a pleasing dark green. A beautiful tree in every way.

3 to $4 \mathrm{ft}$. Each 4 to $5 \mathrm{ft}$. . $\$ 9.00$
J. Virginiana (Red Cedar).-One of the most valuable trees for screens and windbreaks; rerfectly hardy; too well known to need description. Our trees are all extra well shaped and have been several times transplanted.

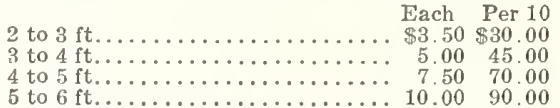

4 to $5 \mathrm{ft}$.

$10.00 \quad 90.00$

J. Virginiana glauca (Silvery Red Cedar).Fine, vigorous grower; cone-shaped, and laving a peculiar whitish color.

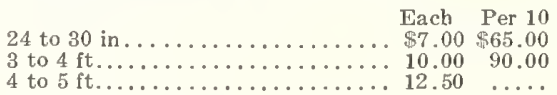

\section{PICEA-Spruce}

P. alba (White Spruce).-Of compact, pyramidal form, and greater symmetry than that of the Norway Spruce, but possibly of less vigorous growth; elegant silvery foliage.

$\begin{array}{rr}\text { Each } & \text { Per } 10 \\ \$ 3.00 & \$ 25.00\end{array}$

18 to 24 in

2 to $3 \mathrm{ft}$ P. canadensis (Black Hill Spruce).-In habit of growth something like P. Alba, except that
foliage is of a bluish green. A very pretty, comfoliage is of a bluish green.
pact growing evergreen.

12 to 18 in

Each Per 10

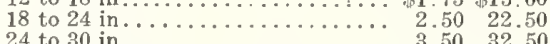

$\$ 1.75 \$ 15.00$ 30 to $36 \mathrm{in} \ldots \ldots \cdots \cdots \cdots \cdots \cdots \cdots$

P. excelsa (Norway Spruce).--Rapid in growth, gracefully drooping in habit, dense in structure, regular in outline and perfectly hardy.

18 to 24 in . . . . . . . . . . Each $\begin{array}{r}\text { Per } 10 \\ \$ 2.00\end{array} \$ 17.50$ 18 to 24 in $\ldots \ldots \ldots \ldots \ldots \ldots \ldots \ldots \ldots . \$ 2.00 \quad \$ 17.50$

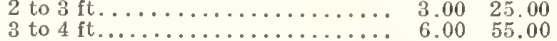

P. pungens (Green From Colorito Spruce).Of pyramidal habit and compact growth; leaves bluish-green. A free grower and perfectly hardy. This is the common variety.

Each

36-inch. ................... \$9.00

P. pungens Kosteriana (Koster's Blue Spruce).Owing to the extreme shortage, we cannot offer this variety this season.

\section{PINUS-Pine}

P. nigra austriaca (Austrian Pine).-From Central Europe. Leaves or needles stiff and dark green. Hardy everywhere and one of the most valuable conifers for windbreaks, belts, etc.

$$
\text { Each Per } 10
$$

2 to $3 \mathrm{ft}$.

P. montana Mughus (Dwarf Mountain Pine).Very distinct, leaves short, stiff, a little twisted and thickly distributed over the branches; does not grow tall, but spreads over the ground, generally assuming a globular form; very dense.

12 to 18 in.

Each Per 10

12 to 18 in ............... \$5.00 \$45.00

P. aylvestris (Scotch Pine).-A rapid grower, very hardy, from the central portion of Europe, with short, rigid, light green leaves. Very valuable for screens and for masses.

2 to $3 \mathrm{ft}$ Each Per 10

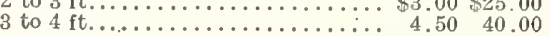

P. strobus (White Pine).-An old and well known native tree of rapid growth and entirely hardy.

2 to $3 \mathrm{ft}$. Each Per 10

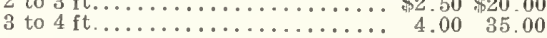

On account of embargo this variety cannot be shipped outside of Missouri.

\section{PSEUDOTSUGA}

P. Douglassii (Douglas Fir).-Large, conical form; branches spreading, horizontal; leaves light green above, glau cous below.

Each Per 10 $\$ 5.00 \$ 45.00$

\section{THUYA-Arborvitae}

T. occidentulis (American Arborvitae).-A well known native species of great value. It and is especially valuable for screens and hedges.

Each Per 10

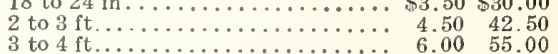

T. occidentalis globosa (Globe Arborvitae).T. occidentalis globosa (Globe
Same shade of green as Pyramidalis.

$15 \mathrm{in}$, wide and $15 \mathrm{in}$ high

Each Per 10 $15 \mathrm{in.}$ wide and $15 \mathrm{in}$. high........ \$3.50\$32.50 T. occidentalis Wareana (Siberian Arborvitae).
Forms a dense, broad, regular pyramid with dark green foliage. Very hardy.

18 to $24 \mathrm{in}$.

Each

18 to 24 in.

T. occidentalis pyramidalis (Pyramidalis Arborvitae).-Of upright pyramidal compact habit. Very desirable.

2 to $3 \mathrm{ft}$

Each

\section{TSUGA-Hemlock}

T. canadensis. $-A$ native species of undoubted worth and beauty. Entirely hardy, with drooping branches and dense habit.

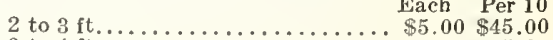

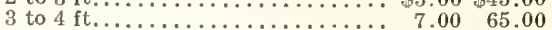

\section{TO OUR FRIENDS AND PATRONS}

Wo would appreciate it if you Would show this copy to some of your friends who may be interested in our products. Will gladly send copy to apyone wishing

Nursery stock in many varieties is very scarce and will be more so for a number of years: some varieties are now unobtainable tThe embars on imported nursery stock of all kinds has were formerly imported from Holland, France, England, Belgium and Japan.

Place your orders at once so that stock can be reserved for you; we shjp soon as weather conditions permit. H. WEBER \& SoNS NURSEPY COMPanY.

The Evergreen should not be overlooked in arranging your plantings. They make your home cozy in winter, when the shrubs are bare. 


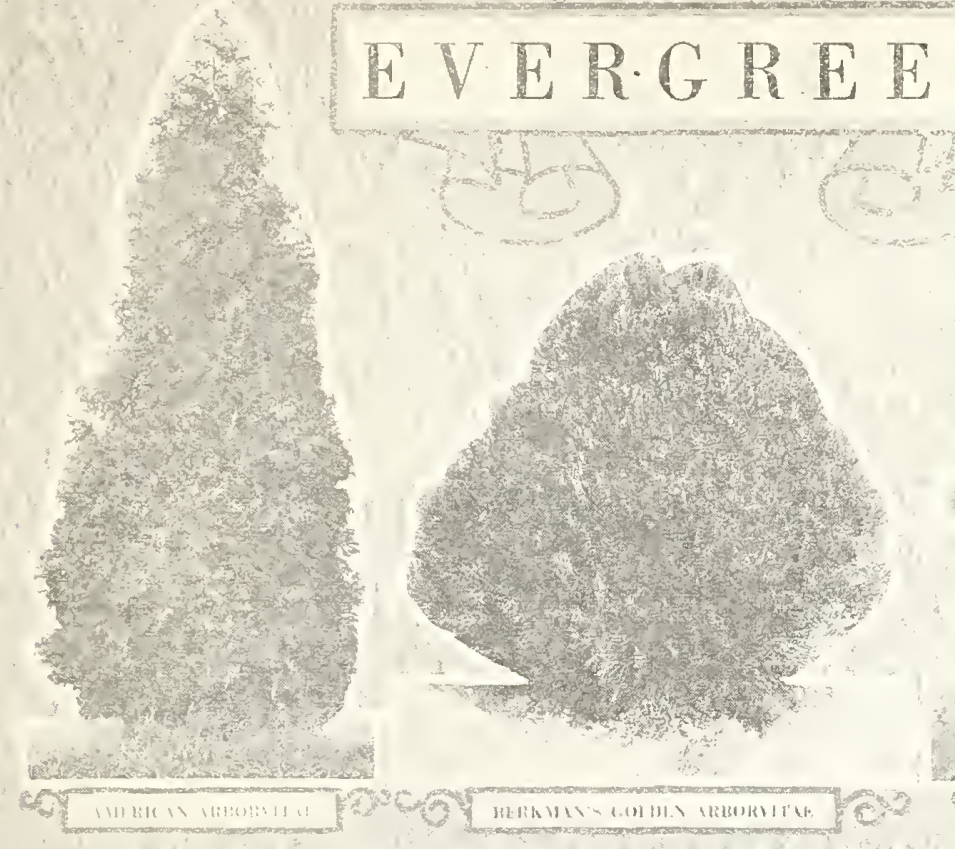

\section{NS}
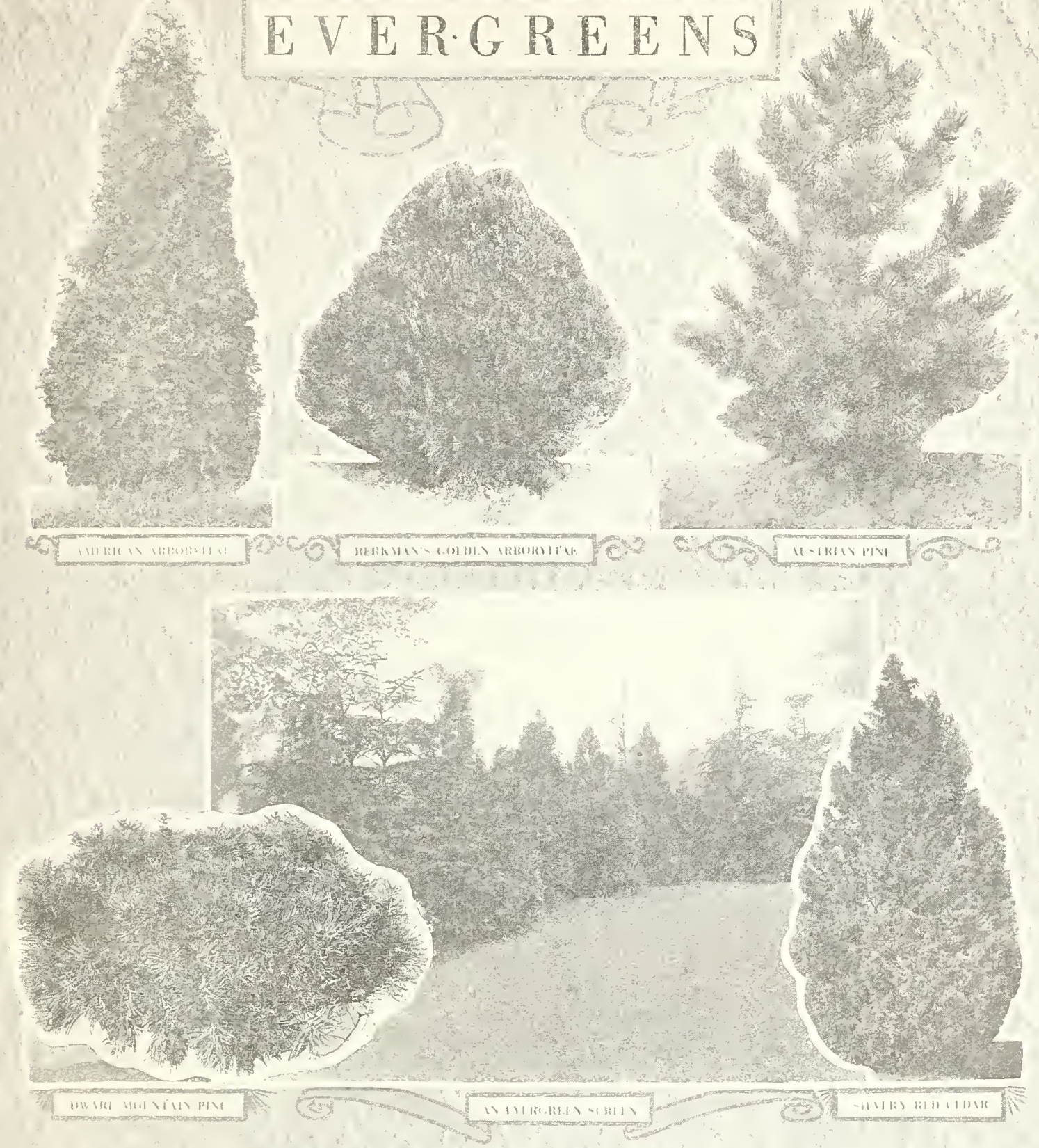

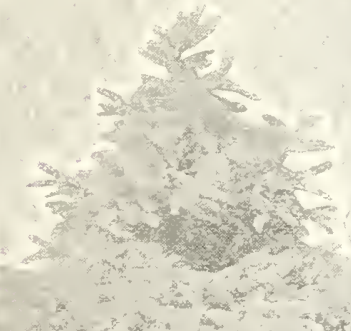

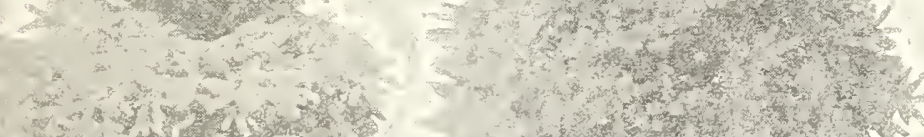
19.

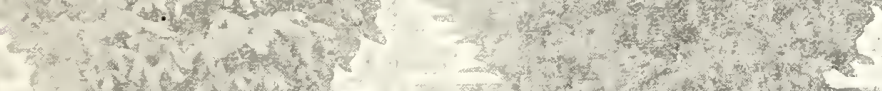

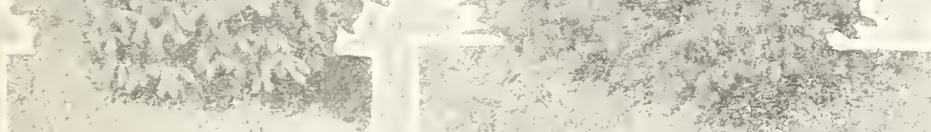

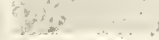

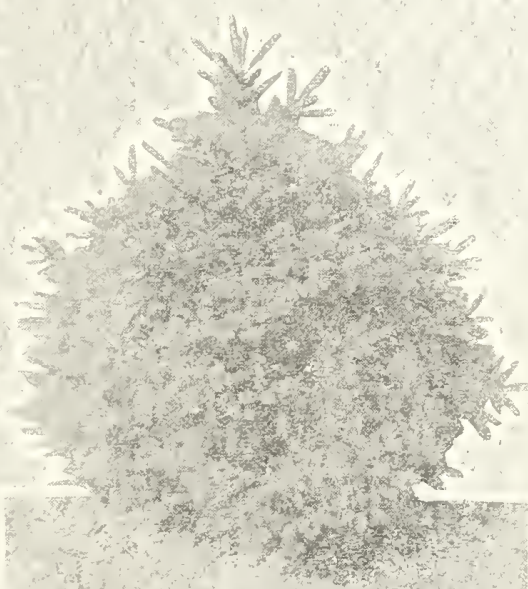

a

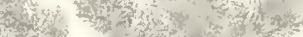

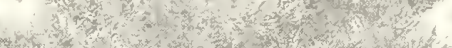
(1) 2.

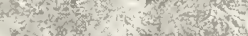
$x_{2} x^{2}$

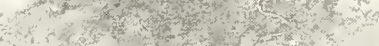




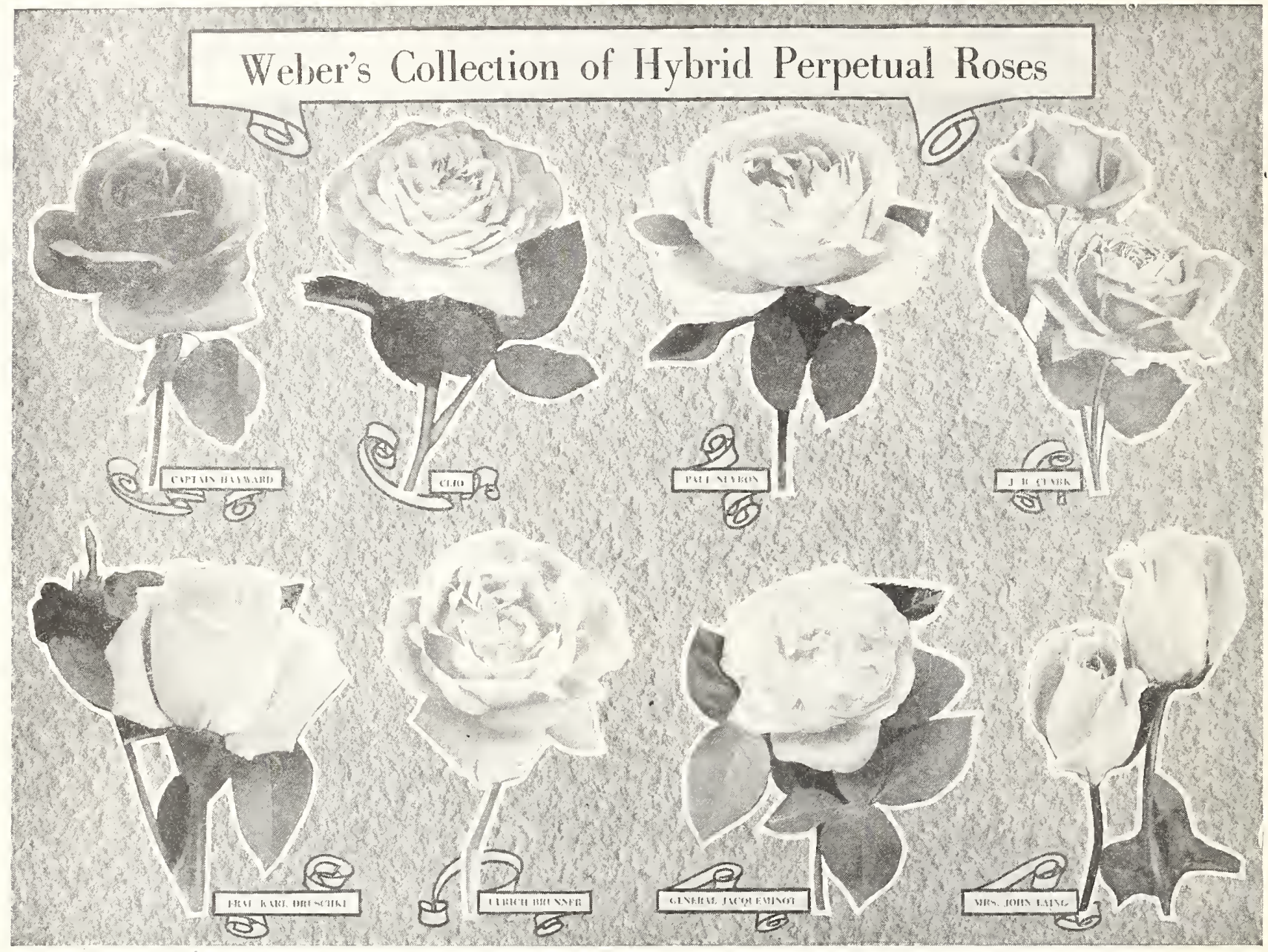

\section{Roses}

Sell. - Roses delight in a clay loam, enriched with well-rotted barnyard manure. Dig up the soil thoroughly to a depth of 12 to 15 inches,

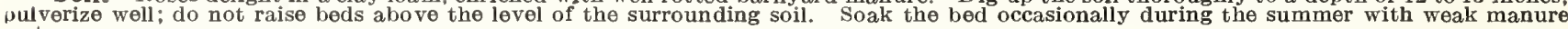
water. Itself.

cation.-Roses delight in an open, airy situation, unshaded by trees and buildings. Always plant in solid beds and each class for

When to Plant.-We advocate planting Hybrid Perpetuals, Ramblers, Prairie, Wichuraiana, Moss, Rugosa, Australian and Sweet

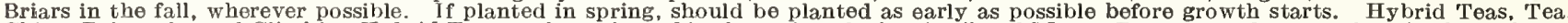

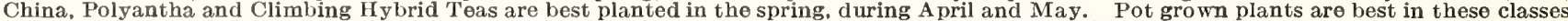
and can be planted the same as Geraniums or other bedding plants at any time after severe freezing weather is past.

Protection. - As soon as severe freezing weather sets in, raise the earth around the plant three or four inches, cover entire bed with dry light manure, then cover with leaves, straw, or evergreen boughs, weighting with light pieces of wood or tree branches.

Soll Conditions. - No Roses should be planted at any time that the soil is in a wet, soggy condition. The soil should be in a loose,

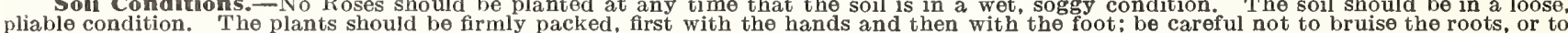

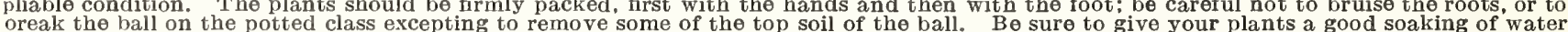

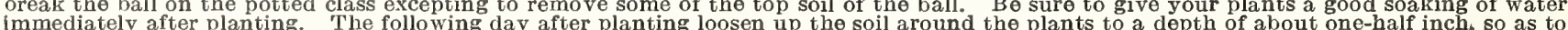

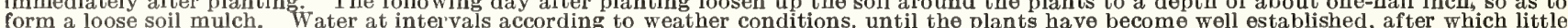

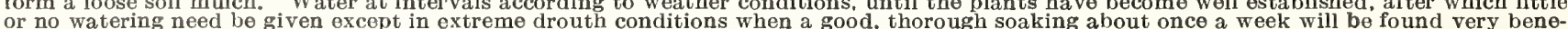

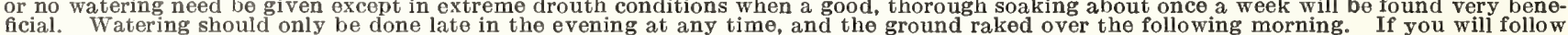
ficial. Watering should only be done late in the evening at any time, and the

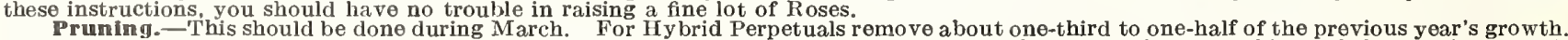

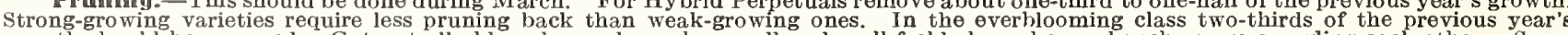

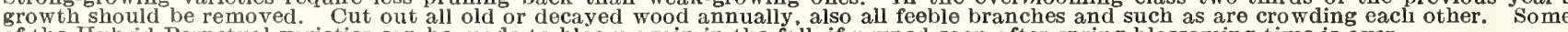
of the Hybrid Perpetual varieties can be made to bloom again in the fall, if pruned soon after spring blossoming time is over.

Insects and Diseases. - Do not let these discourage you. There are now a number of remedies, easily applied, that will rid your plants of any insects very quickly if applied promptly.

\section{WEBER'S SELECTED}

\section{LIST}

HYBRID PERPETUAL ROSES-Rosa Hybrida Cifera

This class of roses is admirably suited for garden culture, for the formation of rose beds, hedges and permanent plantations, where hardy varieties and permanent plantations, where hardy varieties and lusuriant in a deep, rich soil. They are bene. and lusuriant in a deep, rich soil. They are beneaccording to the habit of growth, cutting back close all weak shoots and shortening the long cane to a convenient length.

Prices unless otherwise noted.

Dormant Plants, 2-yr. No. 1. Each, 85c; per 10 , $\$ 7.50$; 7 cr $100, \$ 70.00$.

American Beauty-Rich red. 15c per plant higher than other varieties.

Anna de Diesbach-Shell pink.

Baron de Bonstettin-Rich dark red.

Capt. Hayward-Bright scarlet.

Clio-Flesh color.

Frau Karl Druschke-Pure white.
General Jacqueminot-Velvety crimson. George Ahrendes-Bright carmine rose. Hugh Dickson-Brilliant crimson, shaded scarlet.

J. B. Clark-Intense scarlet.

Mrs. John Laing-Bright shining pink.

Paul Neyron-Beautíul pink.

Ulrich Brunner-Brilliant cherry red. 

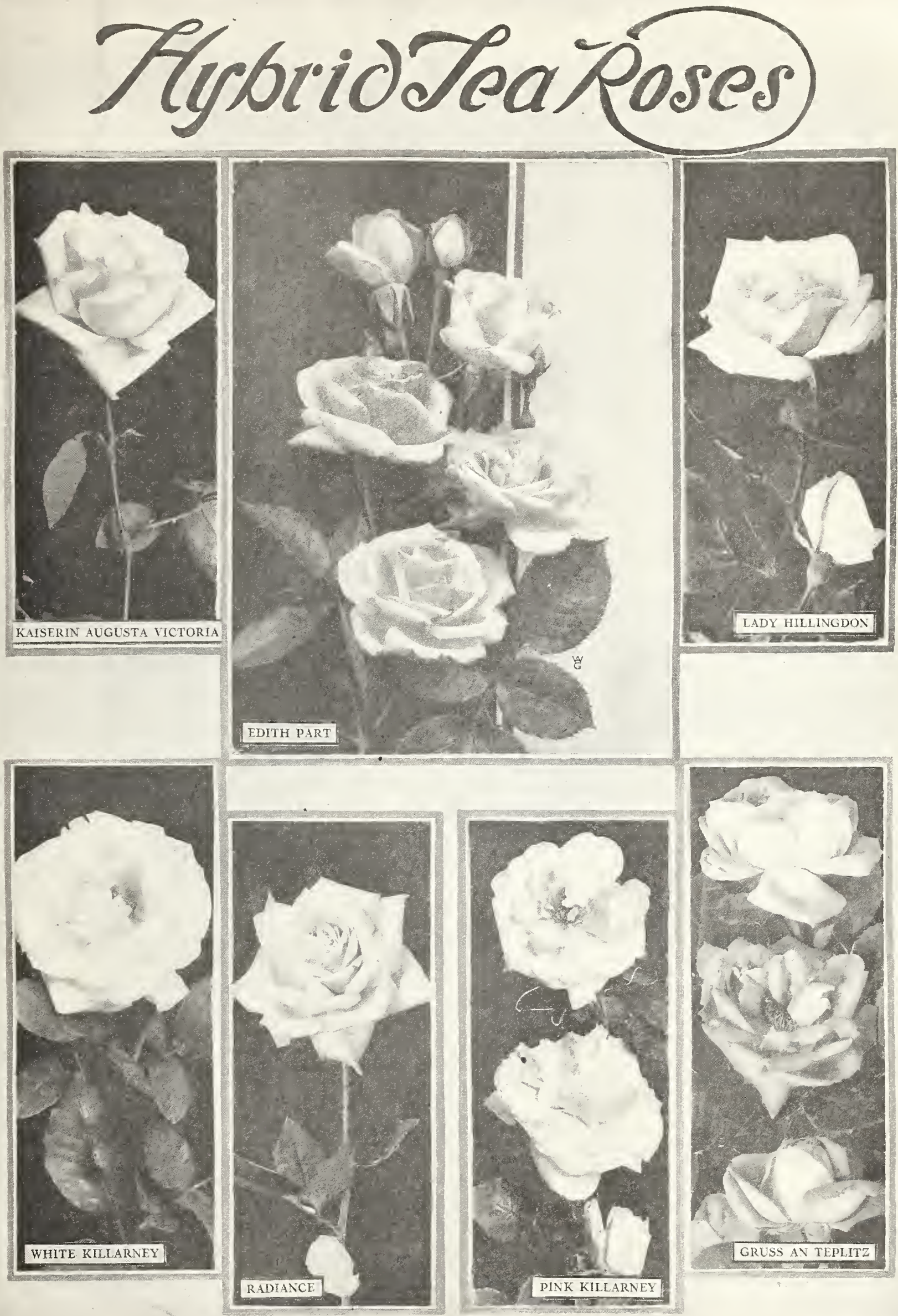


\section{EVERBLOOMING ROSES}

Consisting of Ilybrid Teas. Teas, Bourbon, Ilybrid Polyantha and China or Bengal Roses

Letters H. T. denote Hybrid Tea Roses.

Letter T. denotes Tea Roses.

Letter B, denotes Bourbon Roses.

Letter C. denotes China or Bengal Roses.

Letters H. Pol. denote Hybrid Polyantha.

This class of roses is suitable for general cultivation, as they are usually our very best roses, blooming continuously throughout the season. Require more care in winter protection than do the Hybrid Perpetuals in this climate and further north, but will repay the extra care in a goodly supply of fine flowers when roses of the hardy variety are scarce.

(Not ready for delivery before latter part of April and early May, according to weather conditions. Customers will do well to leave the time of shipment to us.)

NOTICE-In case we are sold out on any one grade, we reserve the right to substitute variety grade, we reserve the right to substitute variety
of same color or send either the next larger or of same color or send either the next larger or it is not desirable that we do this, please so state on your order.

5 and 6-inch pots, 2-year Each Per 10 Per 100

field grown $\ldots \ldots \ldots \ldots \ldots 1.00 \quad \$ 9.00$

4-inch pots, field grown .... $\quad .75 \quad 7.00$

5 and 6-inch pots, 2 -year

extra select field grown., $1: 25 \quad 11.50 \$ 100.00$ May 1st delivery.

Clothilde Soupert (H. Pol.) - Wbite shading to deep pink.

Columbia (H. T.)-Peach-blow pink.

Crusader.-A new introduction. Its growth is sturdy, canes erect, foliage heavy; producing a big F $₹ 110, \$ 11.00$

Dean Hole (H. T.)-Salmon pink.

Duchess of Wellington (H. T.) - Saffron yellow. Edith Part (H. T.)-Rich red, suffused deep almon.

Etoile de France (H. T.) -Clear red crimson velvet.

Farbenkoenigen (H. T.)-Imperial pink.

General McArthur (H. T.)-Vivid crimson scarlet.

General Superior Arnold Janssen (H. T.) Deep carmine red.

Gruss an Teplitz (C.)-Fiery crimson, very hardy.

Jonkheer J. I. Mock (H. T.)—Clear imperial pink.

Kaiserin Augusta Victoria (H. T.)-Pure white, verv fine.

Killarney Brilliant (H. T.)-Bright true pink.

Lady Alice Stanley (H. T.)-Deep coral rose, shading to delicate flesh.

Lady Hillingdon $(\boldsymbol{T}$. $)$-Deep apricot yellow.

La France (H. T.) - Silvery rose.

Laurent Carle (H. T.) -Brilliant velvety carmine.

Miss Lolita Armour (New). - The coloring of this variety is a combination of tints difficult to describe, being absolutely distinct from all other varieties. The plant is a strong, vigorous grower. and free-flowering, producing large sized double and free-flowering, producing large sized double red suffusion, the base of the petals a rich goldenyellow with coppery-red sheen. Fach, \$1.25; yellow with $10, \$ 11.00$.

Mad. Butterfy ( $\boldsymbol{T}$.) -An offspring of the favorit variety Ophelia. All the colors of Opheli's are intensified. making it a symphony of bright pink apricot and gold. Is fuller petaled, more prolific and of greater color appeal. The buds are a rich Indian red, yellow at base.

Mad. Caroline Testout (H. T.)-Brilliant satiny rose.

Mad. Edouard Herriot or Daily Mail (H. T.) Coral-red shading of yellow terra cotta, bronze and geranium red, something of every color.

Mrs. Aaron Ward (H. T.) -Indian yellow.
Ophelia--Brilliant salmon flesh shaded with rose on outer petals, with heart of peach pink. President Taft (H. T.) - Shell pink.

Premier-A magnificent new variety of large size and distinct character, very deep rose color, the broad roll of the outer petals creating most interesting lights and shadows. It is practically thornless.

Prince de' Arenburg (H. T.)-Bright scarlet, shaded purple.

Prima Donna-Lovely shade of vermilion-pink changing to silvery-pink; large and full, perfect form and fragrant.

Radiance (H. T.)-Brilliant rosy carmine.

Red Radiance (H. T.) - A bright, cheerful and even shade of pure red.

Sunburst (H. T.) - Golden orange.

Souv. de Claudius Pernet.-The latest introduction of the great French grower Pernet-Ducher. Long buds, large flower, fast color of sunfloweryellow. Each, $\$ 2.00$; per $10, \$ 17.50$.

White Maman Cochet-A sport from Maman Cochet. Pure white occasionally tinged with blush.

William F. Dreer (New). - Soft silvery shell-pink. Fine for cutting or table use.

Winnie Davis.-Apricot pink, shading to flesh.

Willowmere.-Shrimp pink, shaded yellow and armine.

Wm. R. Smith (T.) - Creamy white shading to pink.

\section{DWARF POLYANTHA, or BABY RAMBLERS} Each Per 10 Per 100

5 and 6-inch pots, 2-year

\section{$\$ 1.25 \$ 11.50$}

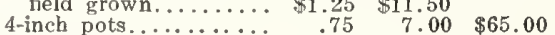

Baby Crimson Rambler (Mme. Norbert Levavasseur).-Brilliant ruby red.

Baby Tausendschoen (Louise Welter).-Rose, reined with soft clear pink.

Baby Dorothy (Maman Levavasseur),-Pure pink.

Cecil Brunner-White shading salmon.

Ellen Poulsen-Dark, brilliant pink.

Erna Teschendorff-Carmine red.

LaFayette-Large brilliant cherry-crimson flowers

in immense branching sprays. A remarkable and valuable kind in any eapacity.

Orleans-Brilliant geranium red.

Triumph d'Orleans-Very deep red.

\section{CLIMBING ROSES-Ramblers and} Trailing Roses

American Pillar.-Large single flowers, carminerose, with cream and yellow center.

$2-$-у., No. 1 . Each Per 10

Climbing American Beauty.-Large red flowers, strong grower, blooms off and on during the summer.

2-yr., No. 1 .

Each Per 10 Per 100

Crimson Rambler-Rapid producer of long heavy canes with rich clusters of blooms, forming a mass of vivid crimson beauty.

2-yr., No. 1.......... $\$ 0.75 \quad \begin{array}{rrr}\text { Each } & \text { Per } 10 & \text { Per } 100 \\ \$ 6.50 & .55 \$ 00\end{array}$ Dorothy Perkins.-Beautiful shell-pink. $\begin{array}{ccc}\text { Each } & \text { Per } 10 & \text { Per } 100 \\ \$ 0.60 & \$ 5.00 & \$ 40.00\end{array}$

2-yr., No. 1......... \$0.60 \$5.00 $\$ 40.00$

Dorothy Perkins (White).-A pure white sport from Dorothy Perkins.

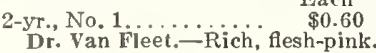
Each Per 10 Per 100 2-yr. No, 1............ wach Per 10
Excelsa (Red Dorothy Perkins)-Clear scarlet; similar to Dorothy Perkins. This is probably the finest of all hardy climbing Roses; should be more generally planted.

Each Per 10 Per 100 2-yr., No. 1........... \$0 60 \$5.00 $\$ 40.00$

Gardenia.-Bright yellow, opening cream; early flowering, fragrant and free.

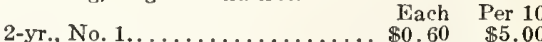

Mary Wallace (New).-Although a good pillar rose, it makes an ideal door-yard bush. The flower are semi-double, bright clear rose-pink with salmon base. These are of extreme size, and appear interheavy bloom. Each, \$1.75; per 10, $\$ 15.00$.

Paul's Scarlet Climber.-Brilliant vivid scarlet color maintained without burning or bleaching
until the petals fall. Flowers medium, semiuntil the petals fall. Flowers medium, semifrom top to bottom. This is without question the most important addition to our climbing roses.

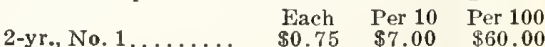
Silver Moon.-Silvery white, with yellow stamens.

2-yr., No. 1............... Each $\begin{array}{r}\text { Per } 10 \\ \$ 090\end{array}$

Tausendschoen (Thousand Beauties), -Varies from pure white to deep pink.

Each Per 10

2-yr., No. 1................. \$0.75 for ground covering.

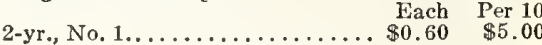

\section{MOSS ROSES}

2-yr., No. 1: Each, \$0.90; per 10, $\$ 8.00$

White Moss.-White.

Henri Martin.-Large deep red flowers.

Crested Moss. - Rose color, beautifully crested.

Salet.-Rose-pink, well mossed.

\section{RUGOSA AND HYBRID RUGOSA}

Price-2-yr., No. 1, each, $\$ 0.85$; per $10, \$ 8.90$ per $100, \$ 70.00$, unless otherwise noted.

Conrad F. Meyer-Clear silvery-pink.

Rugosa Alba.-Single white.

Rugosa Rubra.-Red, single.

2-year, Noch Per 10 Per 100

\section{MISCELLANEOUS ROSES}

Harrison's Yellow.-Deep yellow, hardy. 2-yr., each, 90c; per $10, \$ 8.00$

Rosa Blanda (Wild Meadow Rose).-Bright ose. 2-yr., oach, 50c: per 10, $\$ 4.0$ 9.

Rosa un (Wild Rose)-The familiar redRosa "Wuciaa (Wild, Rose). - The familiar redfruited

4.00. Multiflora-Strong growing, long arching cen whe each, $50 \mathrm{c}$; per $10, \$ 4.00$.

Rosa Palustris (Carolina Rose) (Swamp Rose).Flowers pink. Numerous, June to Septemher. Leaves five to nine lobed. Grows four to seven feet high. Largely used in shrub plantings in the

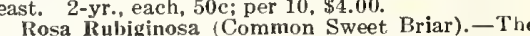
well known old yariety, famous for the fragrance of its foliage, 2-yr., each, 75c; per $10, \$ 6.50$.

Rosa Setigera.-Single, deep rose-colored flower. 2-yr., each, 50c; per $10, \$ 4.00$

Sweet Briar.--See Rosa Rubiginosa.

\section{NEW PERNATENIA ROSES}

Juliet-Fine flowers; petals gold outside, inside rich rosy-red, deepening as the flower expands. Each $\$ 1.00$; per $10, \$ 9.00$.

Soleil d'Or.-A fine, hardy outdoor Rose, showing mucb the same character as the Hybrid Perpetuals. Gold and orange-yellow, varying to ruddy gold suffused with

We are agents for the DEMING line of Spray and Power Pumps. Manufactured by the Deming Co., Salem, Ohio. IIf in the market for a "Spray Pump," write us, tell us number of trees you have to spray and we will be pleased to suggest and price you a suilable outfit. II you are in need of Scalecide, Sulfocide, Arsenate of Lead, Cal-Arsenate, Bordeaux Mixlure, Bordeaux-Lead Arsenate, Nicotine Sulfate 40 per cent, see pages 46 and 47. 


\section{Weber's Collection of Climbing and Trailing Roses}
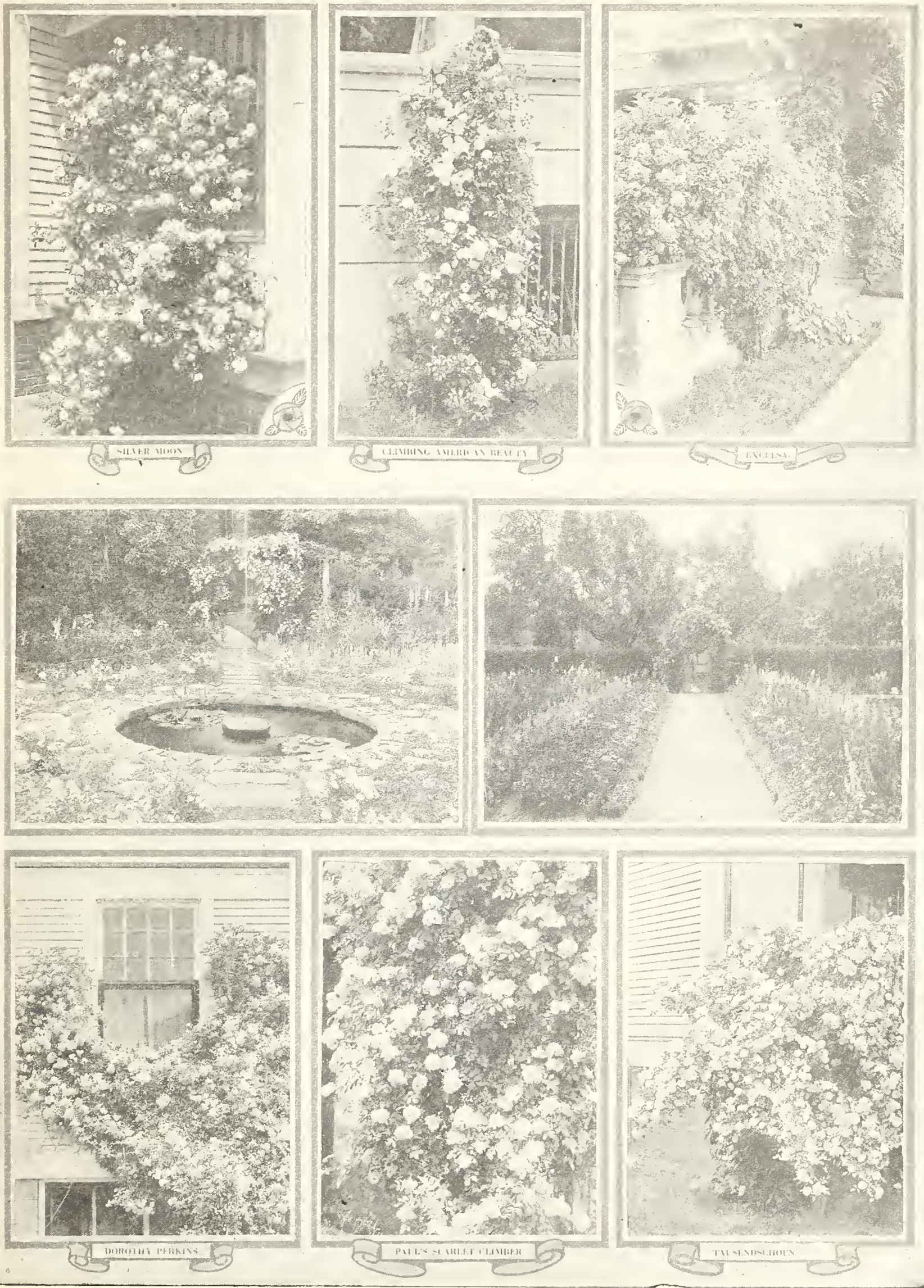


\section{Weber's Select Hardy Perennials}

\section{Plant Flowers to beautify your home grounds, to hide unsightly foundations, in borders or hedge, or in artistically arranged beds, to make your grounds radiate with their beauty and fragrance.}

Although popularly known as old-fashioned plants, Perennials have never been so popular as they are at the present time, and we fee safe in saying that a permanent taste has been developed which is certain to continue and make Perennials as popular in the United States as they have been in the horticultural centers of Europe for many years. Cultivation is of the simplest, beginning with any good soil for a foundation, which may be enriched with any good fertilizer, such as well decomposed cow manure or bone meal, deeply dug, well pulverized. in season as early as possible, so as to enable them to become well rooted and established before hot, dry weather sets in, keeping the ground well stirred, and where it is convenient to water beds during hot, dry weather, a mulch of any loose material, which will keep the soil from baking, will be found very beneficial.

Short grass, the rakings of the lawn after cutting, will be as good for this purpose as anything. given the occasional staking of a plant, the cutting off of decaying flowers, which will prolong the flowering season of many species, and the dividing and replanting occasionally of such varieties that have become too large, being all that is needed.

Our Perennials are mostly all potted in the fall and carried over winter in cold frames. This gives them an excellent root system and they start off in the spring the same as though they had been planted in the fall. They are grown annually from seed or divisions, hence

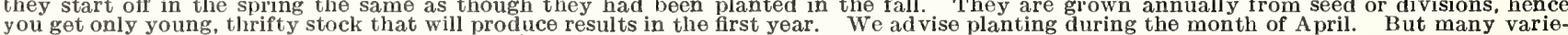
you can be planted all through the month of May.

The Heights given indicate the height Plant attains at maturity.

PERENNIAL CLASSIFICATION LIST

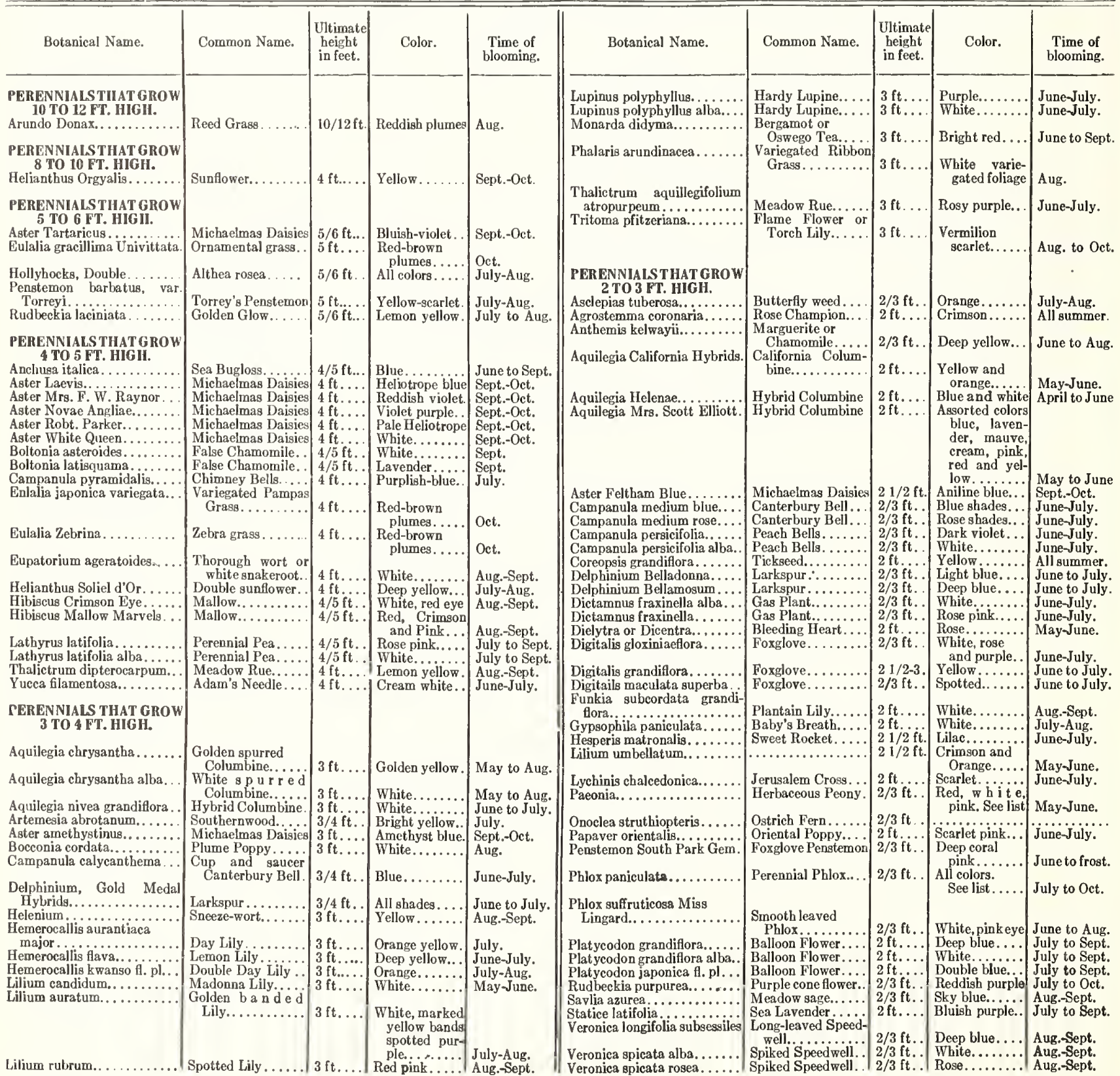


PERENNIAL CLASSIFICATION LIST-Continued.

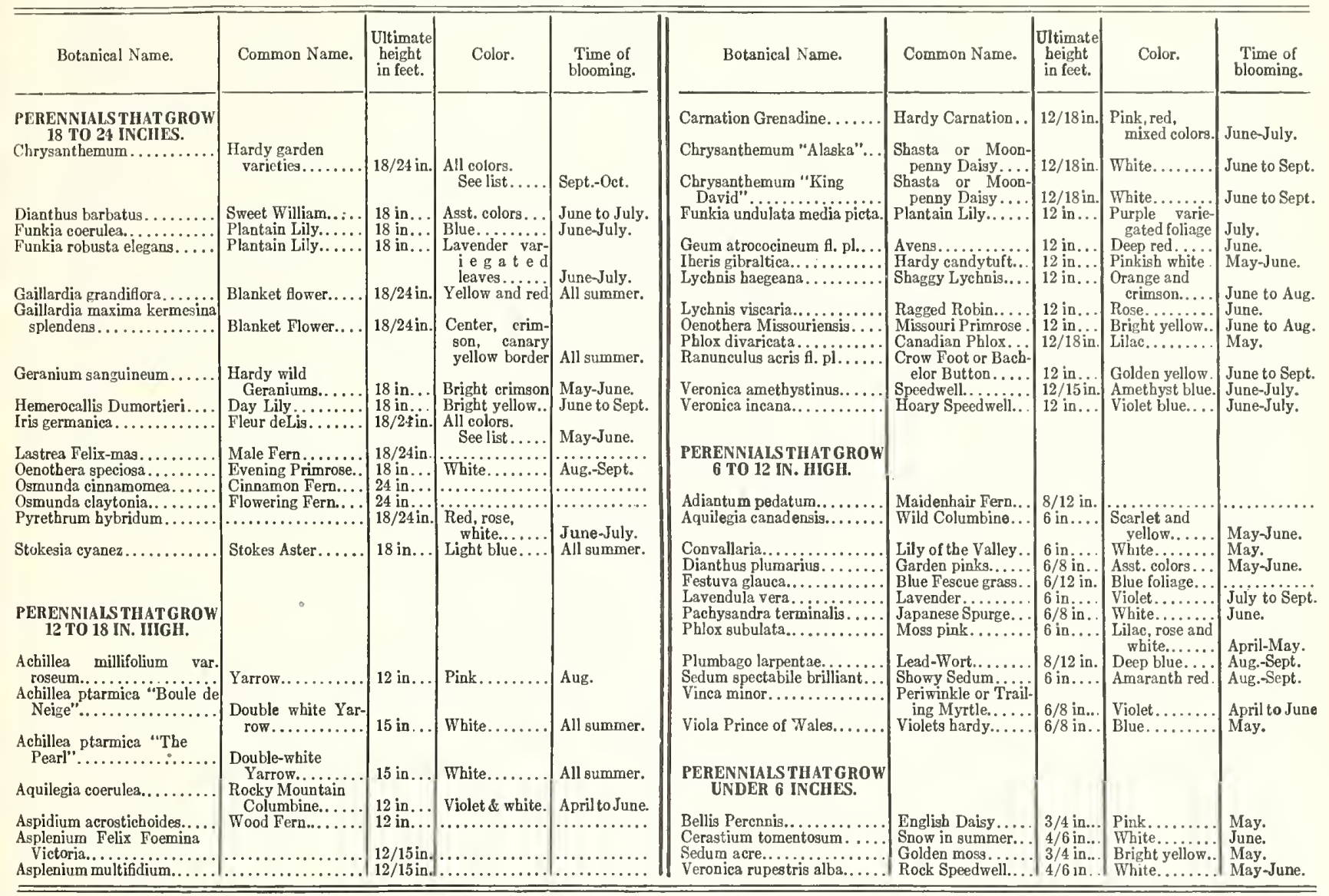

\section{Weber's Hardy Perennials}

\section{ACHILLEA-Milfoil or Yarrow}

A. millifolium roseum (Rose-flowered Yarrow).Rosy-lilac, from June to August. Eacb, 25c; per doz., $\$ 2.50$.

A. Ptarmica "Doule de Neige" (Ball of Snow).Pure white, double flowers. Each, 25c; per doz., $\$ 2.50$.

A. Ptarmica fl. pI. (The Pearl).-Pure white flowers all summer long. Eacb, 25c; per doz., $\$ 2.50$.

\section{Agrostemma-Rose Campion}

A. Coronaria (Mullein Pink).-Bright rosecrimson. Eacb, 25c; per doz., $\$ 2.50$.

\section{ALYSSUM}

A. Saxatile Compactum (Basket of Gold).Showy brigbt yellow flowers; excellent for rock work. Each, 25c; per doz., \$2.50.

\section{ANCHUSA-Sea Bugloss}

A. Italica "Dropmore Variety." - Rich gentian blue. Eacb, 35c; per doz., $\$ 3.50$.

\section{ANTHEMIS-Marguerite}

A. Kelwayi.-Daisy-like golden yellow blossoms all summer. Nice for cutting. Eacb, 25c; per doz., $\$ 2.50$.

\section{AQUILEGIA - Columbine}

A. California Hybrids.-Exquisite flowers, yelow and orange sbades.

A. Canadensis.- Scarlet and yellow native species, one of tbe brightest.

A. Chrysantha (Golden spurred).-Golden yelA. Chrysantha Alba.-Very pretty wbite variety. A. Coern

A. Helenae.-Strong grower, producing numerA. Helenae. - Strong grower, producing numer-
ous flowers of a lovely shade of blue and white. A. Hybrids (Long Spurred). - Large flowers A. Hybrids (Long Spurred). - Large fowers
witb long spurs in blue, wbite, yellow, orange, witb long spurs in blue, wbite, yellow, orange
scarlet and brigbt rose. A. Nivea Grandiflora.-Beautiful large pure

Each, 25c; per doz., $\$ 2.50$.

\section{ARTEMESIA}

A. Abrotanum.-Dark green, finely cut foliage, witb pleasant odor. foliage. Good for carpet bedding. A. Lactiflora (Hawthorn scented).-Elegantly cut dark-green foliage and terminated by panicles of Hawtborn-scented cream

Each, 25c; per doz., $\$ 2.50$.
E

\section{ASCLEPIAS-Butterfly Weed.}

A. Tuberose.-Very showy brilliant orange colored flowers in July and September. Each, 30c. per doz., $\$ 3.00$.

ASTERS-Michaelmas Daisies

A. Amethystinus.-Amethyst Blue, $3 \mathrm{ft}$. A. Feltham Blue,-Pretty sbade of aniline blue, $21 / 2 \mathrm{ft}$.

A. Laevis. - Light heliotrope, $4 \mathrm{ft}$.
A. Mrs, F. W. Raynor.-Reddisb violet, $4 \mathrm{ft}$. A. Novae angliae.-Bright violet purple, $4 \mathrm{ft}$.

A. Robert Parker.-Pale heliotrope, $4 \mathrm{ft}$

A. Tartarieus.-Bluisb violet, late, 6

Each, 25c; per doz., $\$ 2.50$.

BOCCONIA-Plume Poppy

B. Cordata.-A noble plant, beautiful in foliage and witb creamy white flowers during July and August. Each, $25 \mathrm{c}$; per doz., $\$ 2.50$.

BOLTONIA - False Chamomile

Native hardy plant with large single aster-like flowers. Blooms during the summer and autumn months with hundreds of flowers.

B. asteroides.-White.

B. Iatisquama.-Lavender.

Eacb, 25c; per doz., \$2.50.

\section{CAMPANULA-Bell Flower}

C. Medium Blue (Canterbury Bells).-Plants grown from the very best strain of seeds. C. Medium Rose (Canterbury Bells).-Plants rown from the very best strain of seeds.

C. Medium White.-Plants grown from the very best strain of seeds.

C. Calycanthema Blue (Cup and Saucer Canterbury Bells). A very fine clear sbade of blue and flowers nice for cut flowers.

C. Calycanthema White.-Similar to the blue variety, only fiowers are white.

C. Pyramidalis (Chimney Bell Flower).-An at tractive plant for berbaceous borders, forming a perfect pyramid, crowned with large, salver-blue flowers.

Eacb, 25c; per doz., \$2.50 


\section{Hardy Perennials--Continued}

CARNATION-Hardy

A fine border plant for the hardy garden. Grenadine.-Pink.

Grenadine.-Red.

Strong plants to bloom this year.

Each, 25c; per doz.. \$2.50.

CARYOPTERIS-Blue Spirea See Shrubs.

\section{CHRYSANTHEMUM}

\section{Moonpenny Daisy.}

Shasta Daisy "Alaska."- - Large glistening white Howers that bloom all summer. Each, 25c; per loz., $\$ 2.50$; per $100, \$ 20.00$.

\section{CHRYSANTHEMUMS-Aster- flowered Varieties}

Adironda.-A fine bronze.

Angelo.-A beautiful light pink.

Capt. R. H. Cook.-Clear deep rose.

Edina.-Pleasing rose pink.

Excelsior.-Bright yellow.

Julia Lagravere.-Rich garnet.

Juliana.-Fine yellow.

Lilian Doty.-Large incurved pink.

Soliel d'Or.-Fine golden yellow.

Wanda.-Large pure white.

Each, 20c; per doz., \$2.00; per 100, $\$ 15.00$.

Early Flowering Garden and OldFashioned Varieties

Carmelitc.-A splendid yellow.

Idolf.-Pleasing shade of salmon pink.

Lucifer.-Ox-blood red.

Oconto.-Pure white.

Old Homestead.-Light pink.

Bronze (Unnamed).-A fine bronze variety of old-fashioned type.

Each, 20c; per doz., \$2.00; per 100, $\$ 15.00$.

\section{Button-shaped Pompon}

Beth.-Red-wine color.

Iva.-Very small bronze.

LIttle Dot--Early mahogany crimson.

Model of Perfection.-White.

Nio.-Shell pink.

Ouray.-Bright reddish bronze.

Rhoda.-Fine rosy pink.

White Midget.-Pure white.

Each, 20c; per doz., $\$ 2.00$; per $100, \$ 15.00$.

CONVALLARIA-Lily of the Valley The popular little spring flower, for shady places, 1-in. potted plants, each, 35c; per doz. $\$ 3.50$. 4-in. potted plants, each, 35c; per doz,
Dutch pips, per $25, \$ 1.50$; per $100, \$ 5.00$.

\section{COREOPSIS}

C. Ianceolata grandiflora.-The most popular summer cut flower, golden yellow. Should be in every garden. Each, 20c; per doz., \$2.00; per 100, $\$ 10.00$.

\section{DELPIIINIUM-Larkspur}

D. Belladonna.-Free bloomer, June to frost. Flowers turquoise blue. A fine summer cutflower plant.

D. Bellamosum.-The dark blue form of the popular light blue Belladonna with which it is identical in habit of growth, freedom of bloom but with intensely rich, deep blue flowers.

D. Gold Medal Hybrids.-A fine strain of mixed hybrids from England. Very fine.

Each, 30c; per doz., \$3.00; per 100, $\$ 20.00$.

Limited supply extra sized plants. Each, $40 \mathrm{c}$ per doz., $\$ 4.00$

\section{DIANTHUS BARBATUS-Sweet} William

D. Scarlet Beauty.-A fine searlet variety.

D. Maroon (Single).-Almost black.

D. Newport Pink.-An excellent pink variety.
D. Holborn Glory.-A beautiful variety.

Special Mixed.-A mixture of all colors, just the thing for mass planting along walks, or for mixed borders.

Each, 25c; per doz., $\$ 2.50$; per 100, $\$ 15.00$.

DIANTHIUS-Hardy Garden Pinks

D. Delicata.-Soft delicate rose pink. D. Elsie.-Bright, rose with maroon center. D. Homer.-Rosy red with dark center. D. Juliette.-White-laced crimson. D. White Reserve.-An everblooming white. Each, 25c; per doz., \$2.50; per 100, \$15.00.

\section{DICTAMNUS-Gas Plant}

D. Fraxinella.-Rose-pink flowers. D. Fraxinella alba.-Pure white. Each, $35 \mathrm{c}$; per doz., $\$ 3.50$.

\section{DIELYTRA or DICENTRA}

D. Spectabillis (Bleeding Heart or Seal Flower). An old-time favorite. Each, 50c; per doz., $\$ 5.00$.

D. Exima.-Flowers reddish-purple, drooping. Foliage silvery and lanceolated, growing 10 to 18 inches high. Each, 50c; per doz., $\$ 5.00$.

\section{DIGITALIS-Foxglove}

D. Gloxiniaeflora.-A fine strain of finely spotted varieties in colors, wbite, rose and purple.

D. Maculata Superba.-An extra cboice strain of beautifully spotted sorts.

Each, 25e; per doz., $\$ 2.50$; per $100, \$ 15.00$.

\section{EUPATORIUM}

E. Ageratoides.-A useful border plant of strong free growth with white flowers in August and September.

Each, 25c; per doz., $\$ 2.50$; per 100, $\$ 15.00$.

\section{FERNS-Hardy}

Adianthum Pedatum (Hardy Maidenhair).-12 to 18 inches.

spidlum goldiana. -2 to 3 feet tall.

Asplenium Filix Foeminae Victoriae. -15 to 30 nches.

Onoclea Struthiopteris (Ostrich Fern).-24 to 36 inches.

Osmunda Claytonia (Flowering Fern).-24 inches.

Osmunda Cinnamomea (Cinnamon Fern).-24 to 30 inches.

Osmunda regalis (Flowering Fern), -2 to 3 feet tall. $\$ 5.00$

\section{FUNKIA-Plantain Lily}

F. Coerulca.-Blue flowers, broad green leaves. Fach, 35c: per doz., \$3.50.

F. Subcordata Grandiflora.-Pure white, lily shaped flowers in August.

Each, 50e; per doz., $\$ 5.00$

F. Undulata Media Picta-Purple flowers, green and white variegated foliage.

Each, 35c; per doz., $\$ 3.50$.

\section{GAILLARDIA-Blanket Flower}

G. Grandiflora.-One of the showiest of the perennials, excellent cut flowers.

Each, 20c; per doz., \$2.00; per 100, \$10.00.

\section{GERANIUM-Crane Bill}

G. Sanquineum.-A desirable plant with pretty cut foliage and bright erimson flowers.

Each, 25e; per doz., $\$ 2.50$.

\section{GEUM-Avens}

G. Atrococcineum.-A pretty border plant, growing about 15 to 18 inches high, producing showy bright colored flowers from May to June. Each, 25c; per doz, \$2 50 .
GRASSES-Hardy Ornamental

For single specimens, beds or groups on the lawn nothing gives a finer effect than these. They are now largely used in prominent positions in many of the public parks, etc.

Eulalia Japonica Variegata.-A very graceful tall variety from Japan. Long leaf blades, striped with green, white, pink and yellow. Each, 35c per doz.. $\$ 3.50$.

Eulalia Zebrina (Zebra Grass).-The long blades of this variety are marked with broad yellow band across the leaf. Each. 35c; per doz., $\$ 3.50$.

Eulalia Gracillima Univittata-O habit, with a very narrow foliage of bright green color. Each, 35c; per doz., $\$ 3.50$.

Elymus Glaucus (Blue Lyme Grass).-A handsome grass with narrow glaucous silvery foliage, well adapted for the border or edge of beds conweining taller sorts. Grows about three feet high. taining taller sorts. Grows

Erianthins Ravennae.-Gows 8 to 12 feet high. It resembles the Pampas Grass, but blooms more abundantly. Each, 50c; per doz., \$5.00.

Pennisetum Japonicum.-One of the most valuable for beds and specimens.

4-in. pots, each, 25 cents; dozen, $\$ 2.50$

Phalaris Arundinacea (Variegated Ribbon Gras or Gardener's Grass). - Large variegated foliage, an excellent grass for bordering large beds. Each. $25 \mathrm{c}$; per doz., $\$ 2.50$.

\section{GYPSOPHILA-Baby's Breath}

G. Paniculata.-Minute white flowers in gauzelike sprays, exquisite in combination with other flowers when used as eut flowers. Each, 25c per doz., $\$ 2.50$.

Gypsophila Flore Plena.-Beautiful double flowering form; flowers very large and pure white. A valuable subject for a hardy border.

HELENIUM-Sneeze Wort

H. Autumnale Superbum.-Golden yellow flowers in late summer. Each, $25 \mathrm{c}$; per doz., $\$ 2.50$.

HELIANTHUS-Hardy Sunflower H. Orgyalis.-Medium sized yellow flowers in September.

H. Soliel d'Or.-Double golden yellow flowers in August and September.

Each, 25c; per don., $\$ 2.50$.

HEMEROCALLIS-Yellow Day Lily

H. Aurantiaca Major.-Rich Indian yellow with flowers in June.

w. Dumortieri.-Rich cadmium yellow, buds H. Dumortieri.--Rich cadmium yellow, buds
and reverse of petals bronze yellow. Very dwarf. and reverse of petals bronze yellow. Very dwarf.

H. Kwanso fil, pl.-Double orange yellow flowers in July, 25 ; per doz., $\$ 2.50$.

\section{IIESPERIS-Sweet Roeket}

H. Matronalis,-Deliciously sweet scented flowers for the garden and for cut flowers. Each $30 \mathrm{c}$; per doz., $\$ 3.00$.

\section{HIBISCUS-Mallow}

H. Crinson Eye.-Creamy white flowers with large crimson centers. Each, 25c; per doz. $\$ 2.50$; per $100, \$ 18.00$.

H. Mallow Marvels.-A robust type of upright habit, with abundance of flowers of enormous size in all the richest shades of crimson, pink and red. Each, $35 \mathrm{c}$; per doz., $\$ 3.50$; per $100, \$ 25.00$

\section{HOLLYHOCKS}

We have a popular list of these flowers grown in pots and will bloom this year. Double varieties in maroon, red, white and yellow. Also in the beautiful shade of Newport Pink. Each, 30c; per doz. $\$ 3.00$.

\section{PERENNIALS}

We usually begin shipping about April 1st and continue until May. our perennials are mostly pot grown. giving better results than those dug from the Nursery Row. 

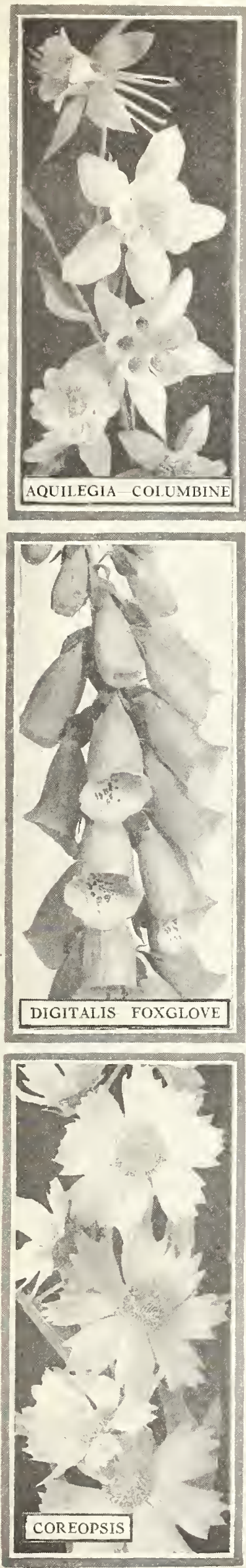
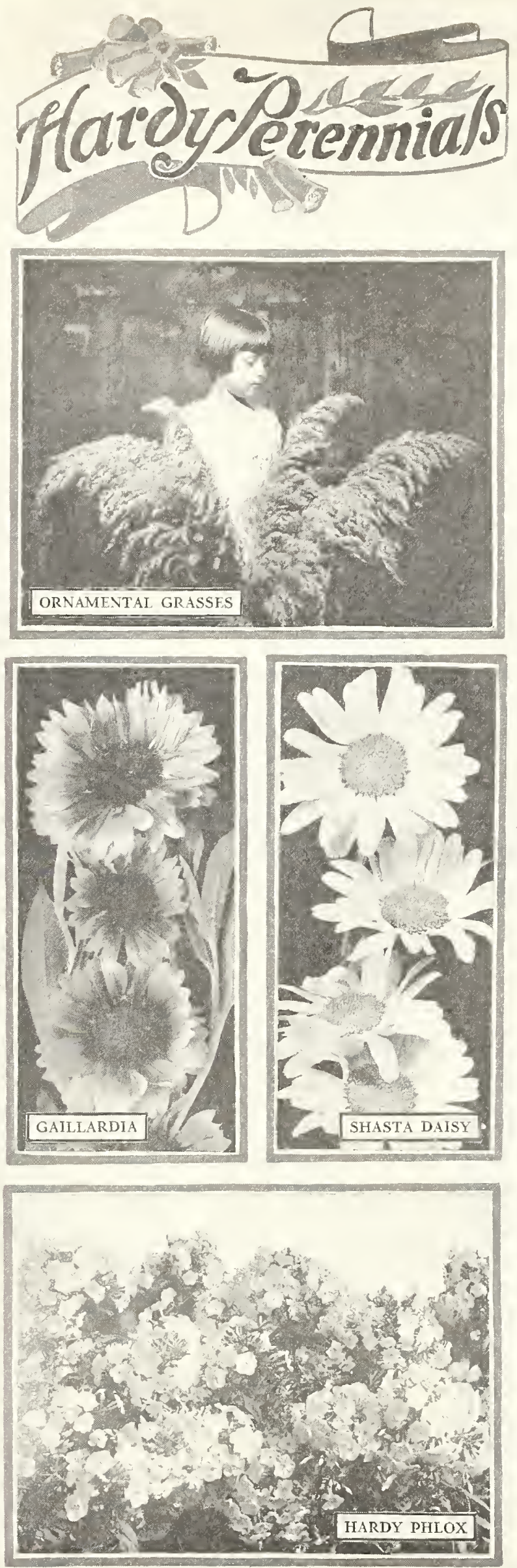
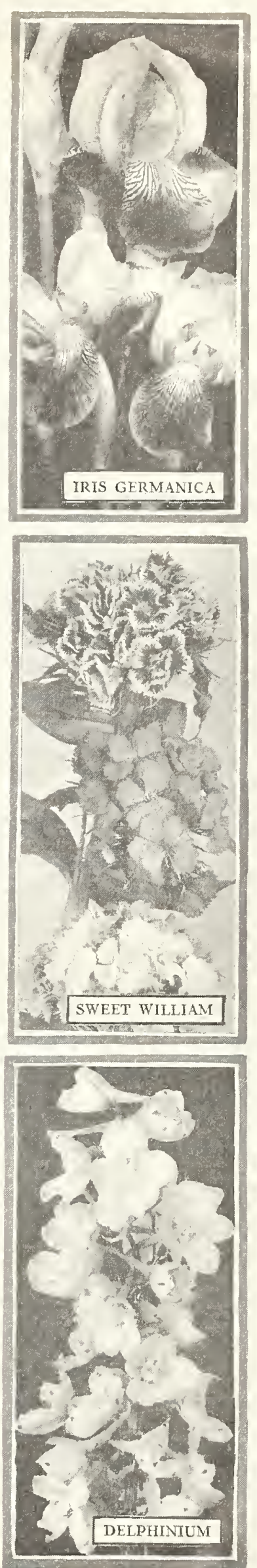


\section{Hardy Peremmials--Continued}

IBERIS-Perennial Candytuft I. Gibraltarica.-Pinkish white flowers. Each, 25 ; per doz., $\$ 2.50$.

IRIS-Germanica-Fleur de Lis Fi. The German Iris is one of the most desirable early spring flowering plants. The flowers are of large size and exquisite colors. No garden should be without a collection of these popular flowers. Our Iris are all potted in 4-inch pots in the fall, hence can be planted any time in the spring and will bloom first year.

Prices unless otherwise noted: Each, 20c; per doz., $\$ 2.00$.

Albert Victor.-S, soft blue: $F$, beautiful lavender. Large flower.

Alcazar.-S, light violet; $F$, deep purple-bronze, veined throat. Each, 50c; per doz., $\$ 5.50$

Celeste. - S, lavender; $F$, deep lavender. Large fower.

Crimson King.-Rich claret purple.

Delicatissima.-Pink, fragrant. Each, 25c; per doz., $\$ 2.50$.

Delmariensis. $-S$, pale gray-hlue; F, darker, shaded violet-brown.

Edith.-S, light plumbago blue; F, purple.

Eldorado--Bronze, good variety. Each, 25c; per doz., $\$ 2.50$.

Fro.-S, golden yellow, edged olive yeliow; F, hestnut brown. Each, $25 \mathrm{c}$; per doz., $\$ 2.50$.

Honorabilis. $-S$, golden-yellow; $F$, rich deep brown.

Jordaln.-Both standards and falls light mauve Khedive.-Both standards and falls soft lavender.

Lent A. Williarns.-A new introduction; very fine. $S$, lavender-violet. Each, $\$ 1.35$; per doz.,

Lohengrin.-Deep violet mauve, large. Each, $25 \mathrm{c}$; per doz., $\$ 2.50$.

Loreley.- $\mathrm{S}$, light yellow; $\mathrm{F}$, blue, bordered light yellow. Each, 25c; per doz., \$2.50.

Mad. Pacquette.-Rosy claret.

Mme. Chereau.-White, elegantly frilled azure blue.

Mrs. Horace Darwin.-S, snow white; F, white, slightly violet at hase.

Monsignor. - S, violet; $F$, velvety purple-crim-

Pallida Dalmatlca.-S, clear lavender-blue: F, deep lavender. Each, 25c; per doz., $\$ 2.50$.

Queen Catarina - Another new introduction: very fine. Azure blue, fragrant. Each, $\$ 2.00$; per doz., $\$ 18.00$.

per lozerwin Wright. $-S$ and $F$, bright clear yellow.

Each, 40c; per doz., $\$ 4.00$
Tamerlan. $-S$, violet hlue; F, deeper. Each, Tamer per doz., $\$ 2.50$.

Violacea Grandiflora.-Deep lavender blue.

Each, 25c; per doz., $\$ 2.50$.

INTERMEDIATE VARIETIES.

Walhalla. $-S$, lavender; $F$, wine red.

Freya. - S, pearl; $F$, flamed violet.

Helge,-Lemon-yellow, pearl shadings.

Each, 20c; per doz., $\$ 2.90$.

DWARF IRIS FOR FDGING.

Pumila.-Purple. Each, 20c; per doz., $\$ 2.00$.

LATHYRUS-Perennial Pea

L. Latifolius.-Hardy climbing pea. We have these in pink and white. Each $30 \mathrm{c}$, per doz., $\$ 3.00$.

\section{LAVANDULA-Lavender}

L. Vera.-This is the true sweet lavender: grows about eighteen inches high. Delightfully fragrant blue flowers in July and August. Each. $25 \mathrm{c}$; per doz., $\$ 2.50$.

\section{LILIUM-Lily}

Lilies do best in the hardy border where they get the benefit of the shade from the surrounding

get the benefit of the shade from the surrounding
plants. Candidum.-The old-fashioned pure white
L. Cand L. Candidum.-The old-fashioned pure white
garden lily. One of the hardiest. 5 and 6 -inch pots, each, 50c; per doz., $\$ 5.00$.

L. Auratum.-Flowers very large, delicate ivory white, thickly dotted with rich chocolate crimson spots. A bright golden band runs through the center of each petal. The finest of all lilies. 6 -inch pots, each, $75 \mathrm{c}$; per doz., $\$ 8.00$.

L. Rubrum.-White, heavily spotted with rich $\$ 8.00$

\section{LUPINUS-Iupine}

L. Polyphyllus.-An effective plant, producing large spikes of clear blue flowers during the latter part of May and early June. Grows about $\mathbf{3}$ feet high.

Each, 35c; per doz., $\$ 3.50$.

\section{LYSIMACHIA}

L. Nummularia (Creeping Jenny or Money. Wort).--Valuable for planting under trees or shrubs where grass will not grow, where it quickly forms a dense carpet. Each, 20c; per doz., \$2.00.

\section{LYCHNIS-Campion}

The Lychnis are of easy culture, thriving in any soil; their bright colors have brought them in high favor with lovers of hardy plants.

L. Chalcedonica (Jerusalem Cross), -Brilliant orange-scarlet flowers all summer; 2 to 3 feet high. L. Haageana.-Brilliant orange-scarlet flowers in May and June. 12 inches.

L. Viscaria.-Forms a dense tuft of evergreen foliage; flowerr spikes of double, deep red, fragrant flowers in June. 1 foot

Each, 25c; per doz., $\$ 2.50$.

\section{PACHYSANDRA-Japanese Spurge}

P. Terminalis. - A trailing plant; glossy green foliage; spikes of flowers in May and June. A cover plant either in sun or shade.

Each, 20c; per doz., $\$ 2.00$; per $100, \$ 15.00$

\section{PAEONIES-Herbaceous}

There is no flower that gives more pleasure to the grower than the Paeonia. It is probably the most grower than the Paeonia. It is probably the most showy spring flowering plant in our entire list of
hardy plants. Easy to grow, requiring very little hardy plants. Easy to grow, requiring very little care and attention, excepting fertilization annually of some well-rotted manure. Every garden should
have a goodly supply of this valuable flower. All have a goodly supply of this valuable flower. All plants will

Duchess de Nemours.-Pure white, early. Each, 50 c; per doz., $\$ 5.50$.

Edulus Superba.-Rose-pink, early. Each, 50c; per doz., $\$ 5.50$.

Festiva Maxima.-White, crimson-flecked center. Early. Each, 60c; per doz., \$6.50.

Francis Ortegat.-Purplish-crimson. Midseason.

Each, 75c; per doz, 88,50

Gen'l McMahon.-Brilliant red. Midseason. Each, 75c; per doz., $\$ 8.50$

L'Esperance.-Rose-pink. Midseason. Each, $50 \mathrm{c}$; per doz., $\$ 5.50$.

Marclel Valliant.-Very dark red. Very late. Each, $75 \mathrm{c}$; per doz., $\$ 8.50$

Mme, de Verneville.-Pure white. Early. Each. $50 \mathrm{c}$; per doz., $\$ 5.50$.

Mme. Ducel.-Silvery-pink. Midseason. Each, 50 c; per doz., $\$ 5.50$.

Mons. Krelage.-Dark red. Midseason. Each, $75 \mathrm{c}$; per doz., $\$ 8.50$.

Officinalis Rubra.-Crimson, fringed leaf. Early. Each, \$1.15; per doz., \$12.00.

Prince Imperial.-Brilliant scarlet. Midseason. Each, 75c; per doz., $\$ 8.50$.

\section{PAPAVER-Poppy}

Orientale Mixed.-Each, 25c; per doz. $\$ 2.50$

\section{PENSTEMON}

P. Barbatus (Chelone).-Brilliant scarlet flowers in June and August. Each, 25c; per doz.

$\$ 2.50$. South Park Gem.-A new variety, heing an improvement on Barbatus Torreyi. Flowers of improvement on Barbatus Torreyi. Flowers of this variety are much closer together and showier on the spikes. The pleasing shade of deep coral pink fowers are produced freely from June until frost. The plant is more compact in growth and at maturity is about thirty inches high. We have a This variety should be planted in every garden. This variety should be pl
Each, 30c; per doz, $\$ 3.00$.

\section{PHLOX SUIFRUTICOSA}

Early Flowering Hardy Phlox.

Miss Lingard. - A very fine white variety, begins to flower after the middle of June and continues throughout the season. Largely used for cut flowers.

Miss Lingard.-Each, 30c; per doz., \$3.00; per $100, \$ 20.00$.
PHLOX

Anton Buchner.-One of the finest white Tvarieies. Med.

Beacon.-Brilliant cherry-red.

Bridesmaid.-White, red eye

Coquelicot.-Clear searlet with crimson eye

Crepescule.-White, rosy-purple eye.

Eclaireur.-Rosy-carmine.

La Vague.-Mauve, red eye.

Mrs. Jenkins (Tall). - Pure white.

M. Paul Dutrie.--Delicate light rose.

Pantheon (Tall).-Bright carmine rose

Rynstrom.-Deep rose.
R. P. Struthers (Tall):-Rosy cherry-red.
Sunset.-Dark rosy-pink.

Each, 25c; per doz., $\$ 2.50$; per 100, $\$ 15.00$.

Elizabeth Campbell.--Salmon-pink. Very fine. Each, 35c; per doz., \$3.50; per 100, \$25.00. Each 30c; per doz., \$3.00; per 100, $\$ 20.00$.

Saimon Queen (New). $100, \$ 20.00$. Saimon Queen (New). A beautiful clear salmon-
pink. Rivals Elizabeth Campbell. Strong, hardy grower. Large flowers and trusses. Each, $40 \mathrm{c}$; per doz., \$4.00; per 100, $\$ 30.00$.

Siebold.-Orange-searlet. Each, 30c; per doz. $\$ 3.00$; per $100, \$ 20.00$.

Special French.-Light pink. Extra fine. Each, $35 \mathrm{c}$; per doz., $\$ 3.50$; per $100, \$ 25.00$.

W. C. Egan.-Pleasing shade of soft pink, very fine. Each, 30c; per doz., $\$ 3.00$; per $100, \$ 20.00$

\section{PLATYCODON-Balloon Flower or} Japanese Bell Flower

P. Grandiflorum.-Deep blue, cupped, starshaped flowers.

P. Grandiflorum alba.-Pure white star-shaped owers.

P. Double White.-Same as Grandiflorum.

P. Double Blue.-Same as Grandiflorum.

Each, 25c; per doz., $\$ 2.50$.

\section{PLUMBaGO-Leadwort}

P. Larpentea.-Of dwarf, spreading habit. Useful for an edging plant or for rockery, covered with beautiful deep blue flowers during the summer and fall months. Each, 25c; per doz., \$2.50.

\section{PYRETHRUM}

P. Grandiflorum roseum.-Mixed colors

P. Hybridum fl. pl.-In colors from deep red Each, 30c., per doz., $\$ 3.00$.

\section{RANUNCULUS-Crow Foot}

R. Acris fl. pl.-A double flowered form of our Bloom

\section{RUDBECKIA - Cone Flower}

R. Laciniata (Golden Glow).-Flowers produced in enormous quantities on long stems and resemble golden yellow cactus Dahlias. Each, 25c; per doz. $\$ 2.50 .5$

R. Purpurea (Giant Purple).-Flowers a peculiar reddish purple with a cone shaped center of brown. Blooms from July to October. Each, 30c; per doz.. $\$ 3.00$.

\section{SALVIA-Meadow Sage}

S. Azurea.-A Rocky Mountain species, growing about two feet high. Produces a great number of sky-blue flowers in August and September. Each, 25 c: per doz., $\$ 2.50$; per $100, \$ 15.00$.

\section{SEDUM-Stone Crop}

The dwarf of creeping varieties; are suitable for rock work, covering gTaves, dry, sunny banks and carpet bedding.

S. Acre (Golden Moss) -CCreeping, foliage and flowers bright yellow. Each, 25c; per doz., \$2.50,

S. Spectabile Brilliant.-A rich colored form of the preceding, being a bright amaranth red. Each $30 \mathrm{c}$; per doz., $\$ 3.00$.

STATICE-Great Sea Lavender

S. Latifolia.-A most valuable plant either for the border or rockery, with tufts of leathery leaves and immense candelabra-like heads. Purplish minute flowers during July and August. Each. 25 c; per doz.. $\$ 2.50$. 


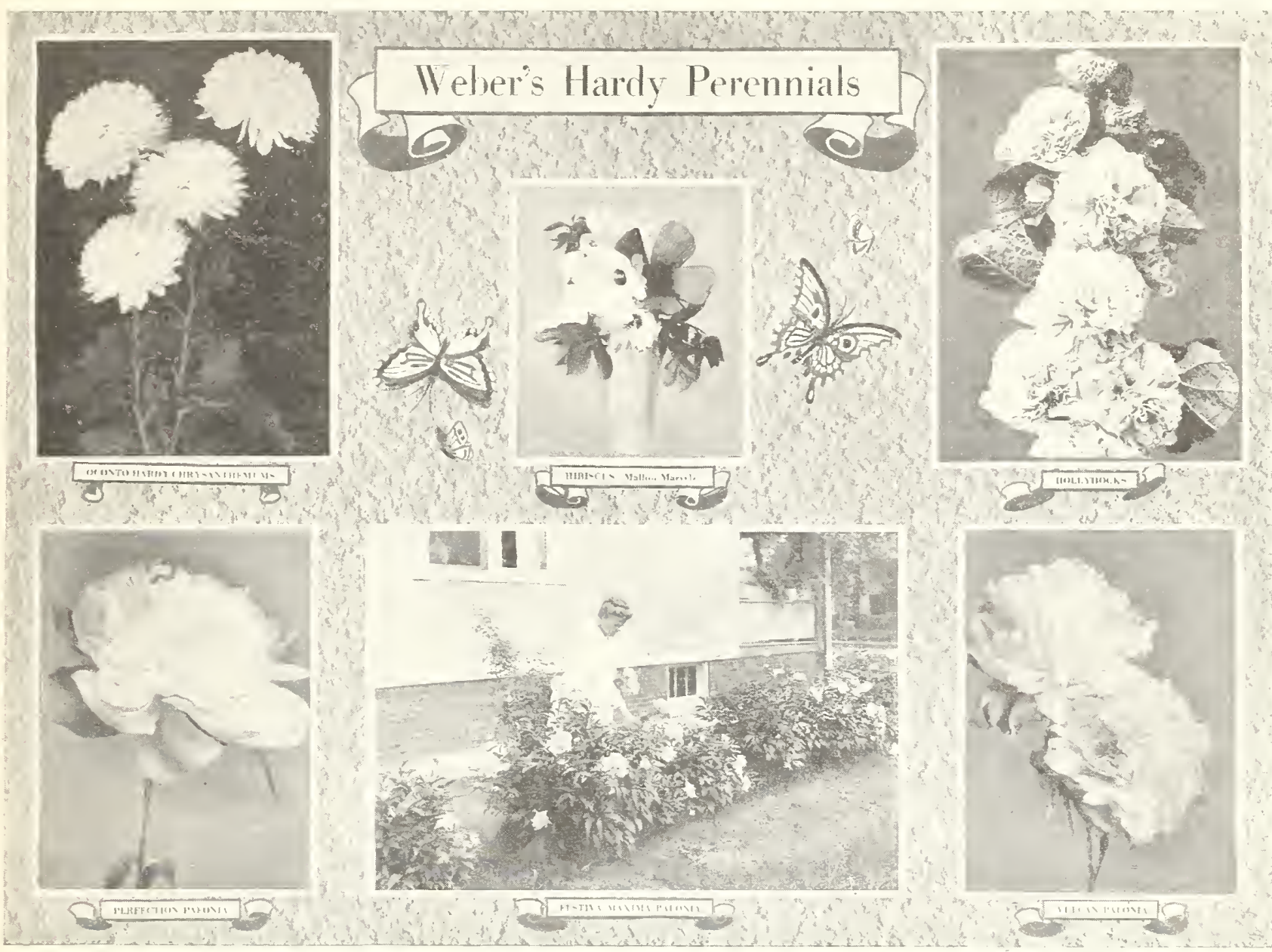

\section{Hardy Perennials.-Continued}

\section{STOKESIA}

S. Cyanea.-One of the prettiest and most distinct hardy plants in our collection. It produces showy, aster-like deep lavender blue flowers from early in June until cut down by frost. Each, $25 \mathrm{c}$ per doz., \$2.50.

\section{THALICTRUM-Meadow Rue}

T. Aguillegifolium Atropurpureum. - Elegant graceful foliage and masses of rosy purple flowers in May to July.

T. Dipterocarpam.-A graceful border plant about four feet high, with pretty, fine-cut foliage, producing lemon yellow flowers in August and September.

Each, 30c; per doz., $\$ 3.00$.

\section{TRITOMA-Flame Flower, or Torch Lily}

P. Pfitzerii.-A grand improvement on Tritoma Uvaria Grandiflora. The spikes, which are produced with considerably more freedom than in the old variety, are of gigantic size, frequently four and a half feet high, and with heads of bloom over twelve inches long, of a rich orange scarlet, shading to
salmon rose on the edge. Each, $30 \mathrm{c}$; per doz., $\$ 3.00$.

\section{VERONICA-Speed well}

Most desirable hardy plants, the fall growing sorts being admirably adapted to the border while the dwarf varieties are excellent rock plants.

v. Amethystina. - Amethyst blue, flowers in June and July.
V. Incana.-Bright, silvery foliage, with spikes of amethyst blue flowers.

V. Longiflora Subsessillis. - Should be planted in the spring; begins to bloom in mide planted continues to mid-August Flowers duly and Should be mulched in winter and watered at times during dry weather.

V. Spicata.-A fine border plant, producing long spikes of white flowers.

V. Spicata Rosea.-A fine border plant, producing long spikes of rose colored flowers.

Each, 30c; per doze colored

\section{VINCA-Periwinkle, or Trailing Myrtle}

v. Minor.-An excellent dwarf evergreen trailing plant that is used extensively for carpeting the ground under shrubs and trees or on graves, where it is too shady for other plants to thrive. Each, $15 \mathrm{c}$; per doz., $\$ 1.50$; per $100, \$ 10.00$.

\section{VIOLAS-Violets}

7. Prince of Wales (English).-Hardy and sweet scented. Each, 20c; per doz., $\$ 2.00$.

\section{YUCCA-Adam's Needle}

Y. Filamentosa.-Among hardy ornamental foliage and flowering plants this can be classed at the head of the list. Its broad sword-like foliage and tall branched spikes of large flagrant, drooping. creamy white flowers make it an effective plant for all positions. Each, $40 \mathrm{c}$; per doz., $\$ 4.00$.

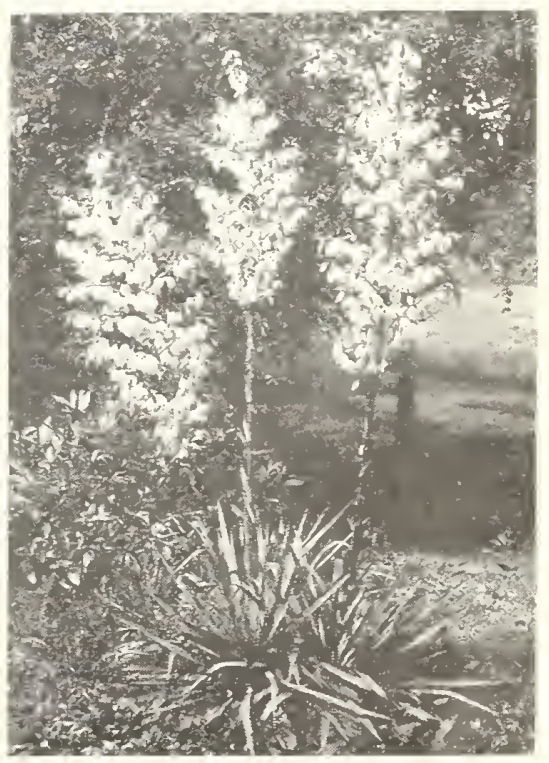

Yucca-Adam's Needle 


\section{Greenhouse Department "Gay Ift with $\mathfrak{J}$ Iomers"}

The have quit growing Cut Flowers and a

TIME OF SHIPMENT.- ive will ship all orders at the best time for planting. If you want special shipments made on certain dates

METHOD OF SHIPMENT.-Greenhouse plants should never be shipped by freight. Express is the proper way to ship this class of plants.

PARCEL POST SHIPMENTS.-Add 10 per cent to amount of bill for local, first, second and third zones; 15 per cent for fourth and fifth zones, and 20 per cent for sixth and seventh zones. We are in St. Louis, Mo., zone.

\section{ACHYRANTHUS}

Brilliantissima.-Bright red foliage.

Each, 10c; per doz., $\$ 1.00$

\section{AGERATUM-Floss Flower}

Stella Gurney.-A fine dwarf blue, fine for bedding and borders.

Each, 10c; per doz, $\$ 1.00$.

\section{AGLAONEMA}

A. Costatum.-A dwarf-growing Aroid, suitahle for the conservatory or window garden. Very compact heart-shaped leaves of dark, shining green, with wbite midrib and scattering blotches of wbite. Each, $\$ 1.00$

\section{ALTERNANTHERA}

Bright foliage plants of dwarf habit, much used for carpet bedding.

Aurea Nana.-Dwarf growing, bright red foliage. Brilliantissima.-Rather broad leaves, busby srowth; mottled hronze and cream, but mostly bright red.

Each, 10c; per doz., $\$ 1.00$

ALYSSUM-Sweet Alyssum

Little Gem (Carpet of Snow). - The dwarf white variety so much used for edging.

Each, 10c; per doz., \$1.00.

\section{ANTHERICUM}

A. Vittatum Variegatum.-A most desirable plant A. Vittatum Variegatum.-A most desirable plant - wor window boxes, vases, or for growing as a single

with white. Each, 30c. habit, but with narrower foliage, the leaves being green on the edges with creamy white center. Each, $30 \mathrm{c}$.

\section{ANTHIRRHINUM-Snapdragon}

Daphne.-Soft blush pink.

Golden Queen.-Ricb, pure yellow.

Firebrand.-Rich, deep red.

Each, 15c; per doz., $\$ 1.50$.

\section{ASPARAGUS}

Sprengeri.-Graceful pot plant for house decoration or for hanging baskets. According to size, $25 \mathrm{c}, 50 \mathrm{c}$. $75 \mathrm{c}$ each. size.

\section{ASPIDISTRA}

The Aspidistra is the easiest of all decorative plants to grow well. Give it a loamy soil and plenty of water, and it will ask for nothing more. $A$ useful plant for the veranda in summer, and for bardiness has no equal as a bouse plant at any
season. It will succeed even in a comparatively dark hall where few other plants would live.

Lurida.-Green leaved.

According to size, $50 \mathrm{c} ; 75 \mathrm{c} ; \$ 1.00$.

BEGONIA-Four Varieties

According to size, $25 \mathrm{c}, 35 \mathrm{c}, 50 \mathrm{c}, 75 \mathrm{c}, \$ 1.00 \mathrm{each}$

\section{CANNA}

A. Crozy.-Very brilliant and attractive, rich crimson scarlet bordered with golden yellow. crimson

Allemania,-Orchid flowered. Salmon with golden markings. 5 feet.

Apricot-A distinct apricot color; very good. 4 feet.

Burbank.-Yellow. 3 feet. Thickly spotted in tbe throat with bright scarlet.

City of Portland.-A new variety of a good deep clear pink: the full petaled trusses are borne freely on heavy stalks, continuing throughout the

David Harum.-Dark bronze foliage; grand grower and free bloomer; fine large flowers with round petals. Bright vermilion-scarlet, dotted with crimson spots. $31 / 2$ feet. Deet.

Favorite.-A good yellow spotted with red dots. Yellow is intense and the dots not too pronounced. $41 / 2$ feet.

George Birdie.-Clear yellow, $31 / 2$ to $4 \mathrm{ft}$.

Gustav Gumper.-Rich golden yellow. $31 / 2$ to fit.

Hungaria.-A beautiful rose pink.

Jean d'Arc-Deep pink, $4 \mathrm{ft}$.

King Humbert.-Bronze leaf, flowers 6 inches in diameter, hrilliant orange scarlet with bright red markings. Good bedding variety. 5 feet.

Louisiana.-Soft, glowing scarlet, with orange throat. 6 feet.

Louis Revershon.-Fine dark leaved variety, lowers large of a cochineal red color. $41 / 2$ to $5 \mathrm{ft}$. Meteor.-Bright blood-red flowers. 5 feet.

Mrs. Dreer.-Yellow flowers, green leaf. $31 / 2 \mathrm{ft}$.

The President.-Most sensational introduction of recent years. Largest flowered, most vigorous growing red Canna. This variety should have a place in every collection.

Venus.-Soft rosy pink with mottled border of creamy yellow. $31 / 3$ feet.

Yellow King Humbert.-A sport of the red flowered King Humbert. Flowers yellow, dotted orange-scarlet.

Prices on above varieties: Each, 20c; per doz. $\$ 2.00$.

\section{COLEUS}

Best plants for carpet bedding and borders for Canna beds.

Christmas Gem.-Leaves very broad, the underside a bright, yellowish very broad, the over and beyond the beaded edge until lost, after fitul struggling, beneath a covering surface of fitful struggling, beneath a covering surface of old rose, pointed here and there with pearl and old rose, pointed here and there with pearl and carmine. A beautiful pot plant for conservatory
use. Prices $15 \mathrm{c}, 25 \mathrm{c}, 35 \mathrm{c}$ and $50 \mathrm{c}$, according to use. Price
size pot.

$\begin{array}{ll}\text { Flambeau } & \text { Prince Leopold } \\ \text { Golden Bedder } & \text { Setting Sun } \\ \text { Brilliancy } & \text { Vershafelti }\end{array}$

21/2-inch pots-Each, 10c; per doz., $\$ 1.00$; per $100, \$ 6.00$.

Trailing Coleus.-For baskets and window boxes. 3 -inch pots, each $15 \mathrm{c}$; per doz. $\$ 1.50$.

$21 / 2$-inch pots, eacb, $10 \mathrm{c}$; per doz., $\$ 1.00$.

\section{CROTONS}

Splendid decorative plants for conservatory use or for use in carpet bedding. Fine selection of

According to size, $30 \mathrm{c}$ to $\$ 2.00$ each.

\section{DRACENA}

Noted for the odd and beautiful foliage.

D. Fragrans.-An excellent house plant with broad dark-green foliage; grows under the most adverse conditions. 4-inch pots, $75 \mathrm{c}$ each.

D. Kelleriana.-Entirely different from the other varieties. Rather compact. Foliage of a leathery texture, rich dark green color, densely marked with spots of creamy white. 4-inch pots, $75 \mathrm{c}$. each.

D. Massangeana.-Broad green foliage with yellow band through the center. 4-inch pots, $75 \mathrm{c}$ each.

D. Mrs. Ed. Andre.-One of the finest highcolored varieties yet introduced with heavy bronz foliage déveloping to an intense hrilliant rosycarmine. 4-inch pots, $75 \mathrm{c}$ each.

D. Sanderiana.-A distinct and pretty variety with glaucous green foliage, edged with a broad border of creamy-white. 3 -inch pots, $35 \mathrm{c}$ each.

D. Terminalis.-Rich, crimson foliage, marked with pink and white.

According to size, $\$ 1.50$ to $\$ 3.00$ each.

\section{FERNS}

Dwarf Boston. Similar to the well-known Boston Fern, only more compact.

Polypodium Mandaianum.-Fronds wavy and undulated and of an attractive glaucous-blue color. Very hardy house plants.

Specimen plants, 8 -inch pots, $\$ 3.00 ; 10$-inch pots, $\$ 5.00$.

Roosevelt.-Dwarf compact grower.

Teddy, Jr.-Very dwarf form of the Roosevelt. Verona.-Very fine foliage.

According to size, $50 \mathrm{c}$ to $\$ 3.00$ each.

\section{FERNS-For Fern Dishes}

We have at all times a good supply of the most desirable varieties.

Pteris Rivertoniana.

Pteris Alba Liniata.

Aspidium Tessineuse.

Holly Ferns.

$2 \frac{1}{4}$ inch pots. $15 \mathrm{c}$ each; $\$ 1.50$ per dozen.

\section{GERANIUMS}

Our list of geraniums is not a long one, but is made up of the most popular bedding sorts

Beacon.-Single deep vermilion scarlet.

Beauty Poitevine.--Rosy salmon.

Bertha de Pressily.-Double delicate pink.

Francis Meehan.-Very pretty double pink variety.

Jean Pabon.-Blood red with small white eye.

John Doyle.-Semi-double, vermilion-scarlet.

Madam Barney.-Double, brilliant rose.

Madam Landry.-Semi-double, salmon shaded orange.

Mme. Recamier.-Double pure white.

Mrs. E. G. Hill.-Beautiful salmon, single.

Mont Mart.-Purplish color.

Red Barney.-Double red.

Ruby.-Double crimson.

S. A. Nutt.-Double, rich dark crimson.

Scarlet Bedder.-Rather dwarf, semi-double, dark fiery red flowers.

Tiffin.- Rich glowing scarlet, shading to crimson on upper petals; single.

Above varieties, each, $25 \mathrm{c}$; per doz., $\$ 2.50$; per $100, \$ 20.00$.

Ivy Leaved.-Fine for baskets or vases or where a trailing or climbing plant may be desired.

Scented Leaves.-Noted for tbeir scented leaves.

We have the rose, lemon and nutmer.

Each, 25c; per doz., \$2.50; per 100, \$15.00.

\section{HEDERA-Ivy}

H. Helix (English Ivy).-A familiar evergreen vine, dark green leaves, favors shady locations. The young wood sometimes winter-kills in this section, due to the action of the sun more than tbe cold. Suitable to cover buildings, rocks, trellis work, graves and as a carpet under trees in places where grass will not grow.

5 -inch pot plants, each $60 \mathrm{c}$; per doz., $\$ 6.50$.

4 -inch pot plants, each $50 \mathrm{c}$; per doz, $\$ 5.50$.

3 -inch pot plants, each $35 \mathrm{c}$; per doz., $\$ 3.75$.

\section{HELIOTROPE}

A favorite flower with everyone.

Each, 25c, per doz., $\$ 2.50$.

\section{HIBISCUS}

Sinensis.-Single, red and pink; double red and pink.

According to size: Each, 25c, 50c, 75c, $\$ 1.00$ $\$ 1.50$

\section{LANTANA}

Well known useful summer bedding plants; the varieties offered are of dwart habit.

Comtesse de Biencourt.-A splendid pink.

M. Schmitt.-A fine yellow.

Jacob Schulz.-Pink and yellow.

Leo Dex.-A fine red.

Each, 25c; per doz., $\$ 2.50$.

\section{LANTANA}

Weeping.-Showy hedding or basket plants.

Each, 20c; per doz., $\$ 2.00$ 


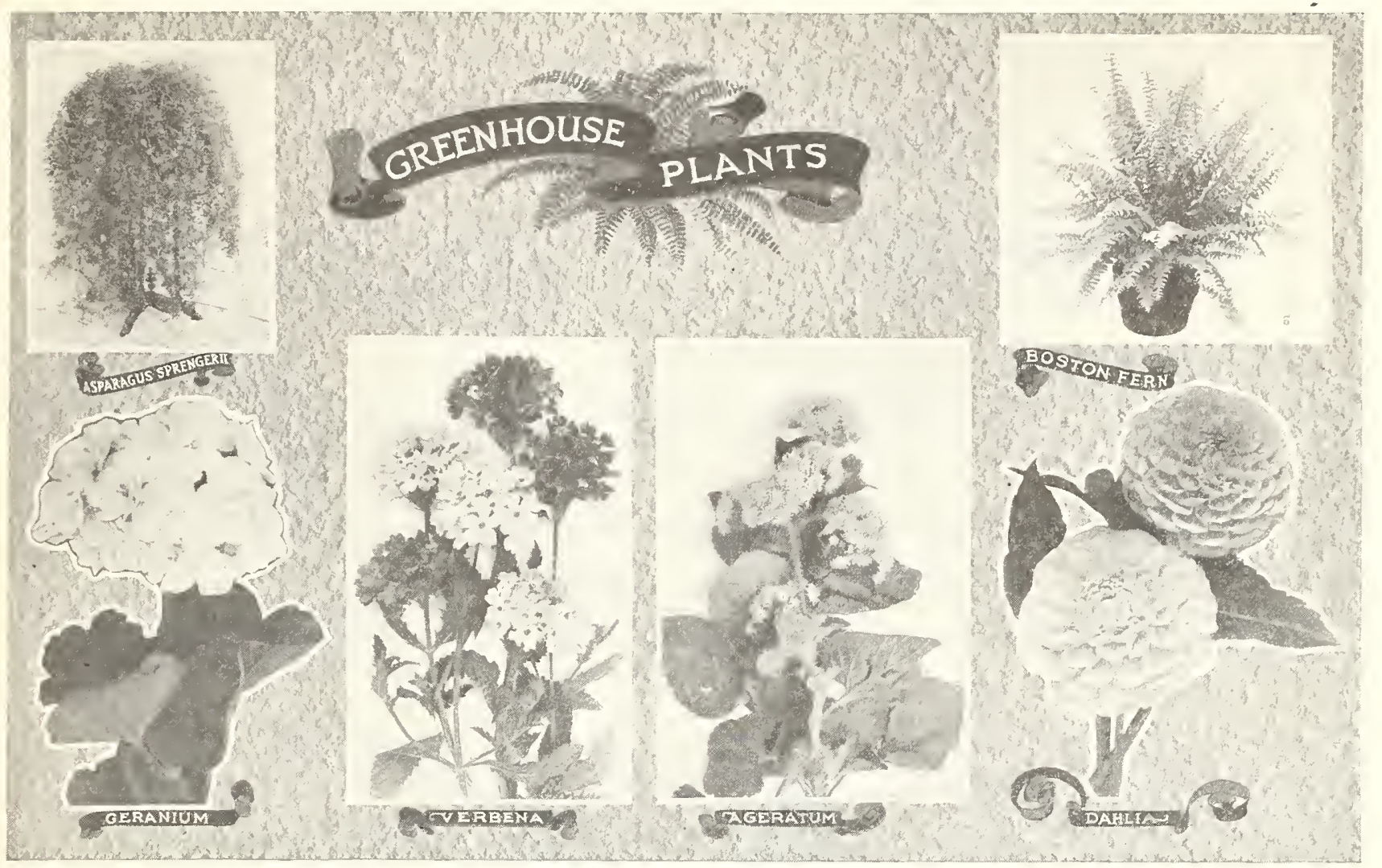

\section{MARAN'TA}

Beautiful variegated foliage plants, suitable for the warm conservatory.

M. Rosea Liniata.- Rich deep-green leaves beautifully variegated with many narrow lines of soft salmon-rose. 4-inch pots, $\$ 1.50$ each.

M. Vanden Heckei.-Rich dark green leaves beautifully variegated with silvery-white. 4 -inch pots, $\$ 1.50$ each.

\section{MARIGOLD}

Both the African and French sorts are among the most popular annuals for bedding and for cut Gowers.

Golden Ball (French).-Pure golden yellow, a fine bedding plant.

Lemon Ball (French). - Light lemon yellow.

Each, 15c; per doz., \$1.50; per 100, $\$ 10.00$.

MESEMBRYANTEMUM-California Pink

Dwarf trailing annual plants. Flowers pink, prized for its singularly icy foliage.

Each, 15c; per doz., $\$ 1.50$.

\section{MOONFLOWER}

Mexican.-The fastest growing climbing annual. Each, 20c; per doz.. $\$ 2.00$.

PELARGONIUMS-Lady Washington Geraniums

Easter greeting.

Each, $25 \mathrm{c}, 35 \mathrm{c}, 50 \mathrm{c}$.

PHILODENDRON, or MONSTERA

Giganteum.-Of strong climbing habit, with large deep green foliage, a splendid wall plant for a

warm conservatory.

Each, 15c; per doz. $\$ 1.50$

PANSY-Mammoth Strain

We will have ten thousand to offer this Spring. Per doz.. 75 c; per $100, \$ \overline{5} .00$.

\section{PALMS}

Kentia Belmoreana.-Of dwarfer hahit than Fosteriana, hut with more spreading leaves. The Kentias are the hardiest house plants. They are of slow growth and are less affected hy dust and dry atmosphere.

Kentia Fosteriana.-Of taller hahit than the

Belmoreana, somewhat heavier foliage.

Phoenix Roebeleni.-Most graceful of the Phoenix and a palm which has become one of the most popular for room decoration. Graceful recurving leaves, with narrow dark green pinnae give it a lightness and airiness not surpassed.

According to size, $75 c$ up.

\section{PANDANUS}

Pandanus Veitchii (Screw Pine).-One of the Pandanus Veitchii (Screw Pine). - One of the best and most attractive decorative plants for the
house. The leaves are light green, heautifully house. The leaves are light green, heautifully According to size: Each, $\$ 1.00$ to $\$ 5.00$.

\section{PENNISETUM-Fountain Grass}

Tender ornamental grasses, valuahle either as individual specimens in the garden or for massing. For border plants for canna beds nothing equal them.

Pennisetum cooperianium.-Pretty bronze foliage and grows three to four feet tall. Fine for ede ing canna heds.

3 -inch pots, each, $25 \mathrm{c}$; per dozen, $\$ 2.75$.

Pennisetum longistylum.-Extremely graceful greenish plumes; excellent for hedding purposes.

3 -inch pots, $15 \mathrm{c}$ each, $\$ 1.50$ per dozen.

\section{PETUNIA}

Double Fringed Mixed.

4 -inch pots, $25 \mathrm{c}$ each. $\$ 2.50$ per dozen.

Single Giant Fringed Mixed.

4 -inch pots, $25 \mathrm{c}$ each, $\$ 2.50$ per dozen.

Each, 15c; doz., \$1.50; per 100, $\$ 10.00$.

\section{PLUMBAGO}

Capensis.-Light lavender blue.

Each, 15c; per doz., $\$ 1.50$.

\section{SALVIA-Scarlet Sage}

Zurich.-A splendid dwarf variety, growing about two feet high, and is especially valuahle on account of heing the earliest to hloom, flowering ten days in advance of any other sort.

4 -inch pots, each, 20c; per doz., $\$ 2.00$; per 100 , $\$ 15.00$.

\section{SANSEVIERA}

Zeylanica.-An elegant variegated plant, especially adapted for house decoration, the thick, leathery leaves standing the heat and dust of the house with impunity.

According to size, $75 \mathrm{c}$ to $\$ 1.50$ each.

Zeylanica Laurenti.-This plant has a band of creamy-yellow, varying from $1 / 4$ to $1 / 2$ inch or more in width on each edge of the leaves, which adds greatly to its decorative effect.

4-inch pots, $\$ 1.25$.

SANTOLINA-Lavender Cotton

S. Incana.-A d warf evergreen perennial with attractive, silvery-white foliage; useful as a rock or horder plant, and largely used for carpet hedding. Each, $10 \mathrm{c}$; per doz., $\$ 1.00$; per $100, \$ 6.00$

\section{TRADESCAN'TIA}

Wandering Jew.-Splendid plants for hasket and window hoxes. Each, 10c and $15 \mathrm{c}$.

\section{VINCA-Vines}

Major Variegata.-A popular plant for vases, haskets and window hoxes, trailing vines. According to size, $20 \mathrm{c}$ to $25 \mathrm{c}$ each; doz., $\$ 2.00$ to
$\$ 2.50$.

\section{VINCA-Periwinkle}

A splendid plant for hedding or for horders, grows 18 to 24 inches high. Always clean and hlooms continuously throughout the summer. Flowers single.

V. Alha.-White

V. Aurea.-Rose.

Each, 10c; per doz., $\$ 1$ 00; per $100, \$ 6.00$.

\section{VERBENA}

We have a nice collection of assorted colors.

Each, 10c; per doz., $\$ 1.00$; per $100, \$ 6.00$.

\section{AQUATIC PLANTS FOR} AQUARIUMS

Fish will not thrive unless some plants are growing to supply oxygen.

\section{ANACHARIS}

A Canadensis Gigantea (Giant Water Weed). A heautiful suhmerged plant with dark greenovate leaves and light stems. $25 \mathrm{c}$ each.

CYPERUS-Umbrella Plant

Alternifolius.-A splendid aquatic plant.

According to size, each, $25 \mathrm{c}$ to $50 \mathrm{c}$

EICHORNIA-Water Hyacinths

Crassipes Major.-A very free-growing and showy floating aquatic, bearing flowers of delicate lilac rose in trusses like a hyacinth. Does splendidly MYRIOPHYLLUM-Parrot's Feather Proserpinacoides.-Long, trailing stems, clothed with whorls of the most exquisite foliage, as delicate as the cypress vine. An aquatic plant.

Each, 10c; per doz., \$1.00.

We invite every flower Iover to isic our "GREENHOUSES" and see the large line of plants we carry. 


\section{SPRAYING}

\section{Simple - Easy - Effective}

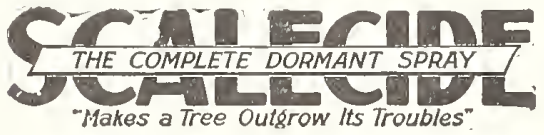

Any fruit grower who understands the value of Scalecide will select it as his regular dormant spray. Scalecide is truly "the complete dormant spray." When you spray with Scalecide, you can rest assured that you have done al that can be done, at that particular time, hy any dormant spray or combination of sprays. Scalecide is the quality miscihle oil. It is a profit maker and not merely a bug killer. The invigorating effect alone is worth the cost. Many of the finest orchards are sprayed every year with Scalecide. Dilute one gallon to fifteen gallons of water.

Kills Scale.-Scalecide kills scale almost instantly and does a thorough job. It smothers the scale with a film of oil. It creeps under the protective scales and into the cracks and crevices of the rough bark. It controls scale even when and into the cracks and crevices of the rough bark. It controls scale even when has done its work-no amount of rain after that affects its efficiency.

IKills Aphis Without Nicotine.-If aphis control is one of your serious orchard problems, this alone is sufficient reason for your use of Sealecide. 'The fact that Scalecide controls aphis, without nicotine, means much more than the saving of the cost of nicotine. It means the control of aphis, year in and year out, by the simple method of spraying with Scalecide as a delayed dormant spray.

Kills Eggs of Leaf Roller and Red Mite.-Scalecide again demonstrates its effectiveness, as the complete dormant spray, hy killing insect eggs wintering effectiveness, as the complete dormant spray, hy killing insect eggs wintering on the tree. Best control is ohtained by applying Scalecide, as a delayed dormant spray, as near hatching tim $121 / 2$; for red mite, 1 to 15 .

Kills Fire Blight Cankers.-If your orchard is infested with fire blight, try Scalecide this year. Scalecide penetrates and kills the infectious hold-over cankers, allows the wound to heal, and checks the spread of fire blight, without pruning or cutting. Fire hlight control is an extra henefit from the annual use of Scalecide to control scale and other pests.

Kills Fungous Spores and Fungous Cankers.-Scalecide is the only oil spray which is also a fungicide. And Scalecide, unlike any other fungicide, pene trates diseased tissue and is therefore effective against more fungous trouhle than a mere surface spray like lime-sulphur. Applied before the huds swell, Scalecide controls peach leaf curl. Brown rot cankers, black rot cankers, collar rot and root rot yield to treatment with Scalecide.

Guaranteed to Make a Better Orchard Than Lime-Sulphur.-The manufac turer's guarantee that, if an orchard is divided in two parts, one part heing sprayed with Scalecide, and the other part with lime-sulphur for three years, other things being equal, the part sprayed with Scalecide will be better than ther things being equal, the part sprayed with Scalecide will be better than the part sprayed with lime-sulphur, or they will refund
paid for the Scalecide. Ask for copy of the guarantee.

Invigorates Your Trees.-Scalecide applied regularly every year gives your trees the vigor required to produce hoth fruit and bud. The leaves of the Scalecide-sprayed tree are larger and darker green and they hang on later in the fall. Thus they enable the tree to build up more starches and sugars and properly nourish the fruit spurs.

Saves Labor.-Twice as much dilute lime-sulphur as dilute Scalecide is required to spray the same trees. The saving is not only in applying half as quired to spray the same trees. The saving is not only in applying half as much material but especially in filling and hauling one-half as many spray busy days of spring.

Saves Haulage.-Instead of sending a truck to the station for a fifty-gallon barrel of lime-sulphur, weighing 600 pounds, you can bring home a fifteengallon drum of Scalecide, weighing 135 pounds, on the running board of your car. This 135* pound drum of Scalecide weighs even less than enough dry lime-sulphur (150 lhs.) to spray the same trees.

Pleasant to Use.-When you spray with Scalecide, you do a way with slickers and gauntlets and goggles. You will enjoy spraying with Scalecide-it is so pleasant to use. You can look straight at your work, without fear of injuring your eyes. Fruit growers say, "The job I used to dread so much before, I now actually look forward to. I like to spray with Scalecide."

\section{SCALECJDE PRICES}

F. O. B. St. Louis, Missouri. 50 -gal. bhls..........\$38.00$$
30 \text {-gal }
$$

15 gals.

Drum

$\$ 11.50)$ 13.50

Two 5-gal. cans........... 10.60

One 5-gal. can......... 6.25

One 1-gal. can

1.75

.75

One 1-qt. can.
Briefly, these are the reasons why Sulfocide is " a hetter summer spray:" It does not russet apples (bordeaux does); it does not devitalize the foliage and dwarf the fruit (lime-sulphur does); it can he used on both peaches and apples and on all kinds of fruits and vegetables (no other fungicide can); it imparts to the fruit a heautiful lustre and finish; it costs no more than home-made bordeaux. Sulfocide is a highly concentrated, non-poisonous, liquid sulpbur fungicide, quite distinct from lime-sulphur.

A Powerful Fungicide.-Witbin a few minutes after the Sulfocide spray is applied, the sulphur is precipitated by the action of the carbonic acid gas of the plied, the sulphur is precipitated by the action of the carbonic acid gas of the air. This precipitated sulphur is manufactured right on the leaf, where you want it, and is so fine that it is scarcely visible, except where drops accumu-
late. This is sulphur in its strongest fungical form, for the finer the sulphur the greater is its fungicidal action.

Used On All Kinds of Fruits, Vegetables and Flowers.-Where peaches and apples are interplanted, there is no fungicide, except Sulfocide, which is at the same time safe for peaches and effective in the control of apple diseases. Sulfocide is the only fungicide which can be used on all kinds of fruits, vegetables and flowers.

Controls Apple Scab.-The control of apple scab is in some seasons the most difficult problem of the apple grower. Sulfocide is not only an effective fungicide for scah control, but it does not injure chlorophyl and does not turn scab spots black. Do not take chances with apple scah-spray with Sulfocide and prevent it.

Stops Brown Rot.-Sulfocide controls brown rot of peaches, plums, cherries, etc. It even checks brown rot after it has started and keeps it from spreading. We know of no other fungicide that will do this. Failure to set fruit is often due to brown rot attacking the hlossoms. Spray early-just as the buds swell and before the hlossoms open-to protect the blossoms.

Retards Decay In Marketed Fruit. - The day before picking, spray the fruit thoroughly, using 1 gallon of Sulfocide and 3 pounds of any good odorless soapnot fish oil soap- to 200 gallons of water. This covers the fruit with a film of extremely fine sulpbur, which retards decay and at the same time can neitber he seen nor tasted and is non-poisonous and harmless. One Gallon Makes 200 Gallons of Spray.-Sulfocide is a very concentrated
spray material and a little of it goes a long ways. For most purposes dilute spray material and a little of it goes a long ways. For most purposes dilute Sulfocide, 1 gallon to 200 gallons of water. For potatoes, use 1 gallon to 150
gallons of water. The low cost of Sulfocide is due to the fact that it goes so gar.

Convenient to Use.-Sulfocide is so convenient to use-just pour it into the water and spray. It is a clear liquid, containing no grit or sediment. Tbere is nothing to clog the nozzle or eat out the valves. Because of the great dilution the spray is non-caustic. Sulfocide may he combined with nicotine for aphis.

Cost is Low.- Sulfocide costs no more than home-made bordeaux, commercial lime-sulphur, self-hoiled lime-sulphur or dry-mix. A fifty-gallon harrel of Sulfocide costing $\$ 60.00$ makes 10,000 gallons of spray. The low cost of Sulfecile makes it the idea spray for the commercial fruit grower.

Combines With Cal-Arsenate.-Sulfocide may be combined with a good grade of calcium arsenate (arsenate of lime) with or without Kayso. However, we recommend the use of Kayso, whenever convenient, for when Kayso is mixed in the water first, it tends to neutralize any arsenical residue which may he in the spray tank. Combines With Kayso and Arsenate of Lead.- We can now recommend tbe
new comhination of Kayso ( $\mathrm{mix}$ it in the water first), and arsenate of lead (mix it in the water second), with Sulfocide (mix it in the water last). Always mix in the order named. Add the Sulfocide after all the water has been put in the in the spray tank. Use only plain arsenate of lead-in the case of an arsenate of lead containing a so-called self-spreader, there is apt to be burning.
CARBOLEINE

The safest and most effectlve low priced oil spray on the market since 1907. It mixes instantly in any kind of water and stays mixed. Diluted 1 to 20, Carboleine kills scale, aphis and many other pests. But it does not have fungicidal or invigorating properties and does not control fire-blight cankers-Scalecide is the only oil spray that has these advantages. You can buy Carboleine at $\$ 20.00$ per 50-gallon barrel F. O. B. Hackensack, N. J., with full assurance that no dormant spray-except Scalecide-will serve you so well.

\section{SULFOCIDE PRICES}

F. o. B. St. Louis, Missouri. 50 -gal. bbls...........\$60.00 30 -gal. bbls 39.00

Two 5-gal. cans......... 15.00

One 5-gal. can.......... 8.75

One 1-gal can.......... 2.75

One 1 -qt. can.............. 1.00

One 1-pt. can........... .7 


\section{SPRAY PUMPS FOR ALL PURPOSES}

We are agents for the well-known DEMING PUMPS. As our space is limited we can only show a small portion of the various styles we carry. If you are in the market for a pump, kindly send for a catalogue, showing a complete line. Free to all applicants.

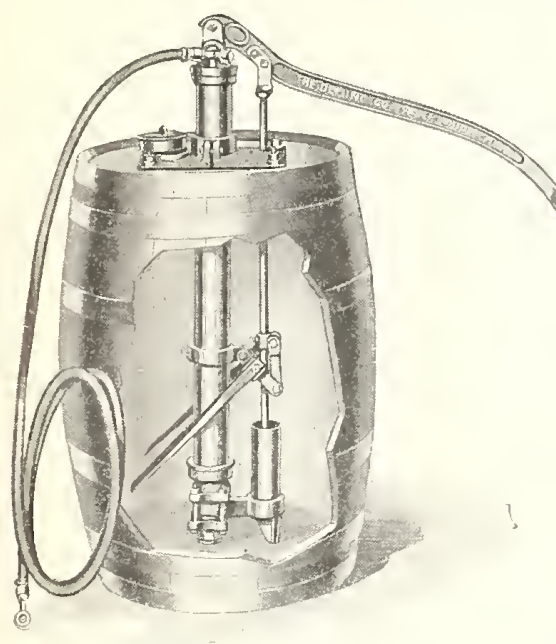

Fig. 645-THE "CENTURY"

The acknowledged leader of all harrel pumps for more than twenty years. Will supply two leads of hose and four nozzles.

Universal iron base-adjustable to any size or depth of barrel-fits the flat head or curved side of barrel. Base fits 7x10-inch hole. Filling hole in base for mixtures. Valves may be quickly in base for mixtures. Valves may be quickly reached hy removing four holts. Twin paddle agitator; $21 / 4$-inch all-brass cylinder; brass ball valeel tuhing, 32 inches long. Barrel not furnished unless so ordered.

One 121/2-ft. section of "Deco" hose and one nozzle supplied with pump.

Shipping weight, boxed, 75 pounds.

Outfit $\mathrm{A}$-as deseribed above......... $\$ 18.30$

Outfit B-with 2 leads of $121 / 2$-ft. hose and

2 nozzles........................

Pump only-without hose or nozzles.....

22.25

Barrel, painted, and cut ready for mount-

14.30

ing pump......................

Don't let insects eat your fruit, that is what these sprayers are for.

THE "GARDENERS' CHOICE"
A "One-Man" Machine

This is a very convenient outfit for general use. The pump is fitted with mechanical agitator and is good for 125 pounds pressure. It has a large air chamber. Working parts are hrass.

Tank holds 24 gallons; has hinged wood top. Leg, tongue and handle are wrought iron pipe. Metal wheels, diameter 24 inches, with staggered spokes and 2-inch tires 24 inches, with staggered tank, 30 inches; height to top of pump, 42 inches. Sink, 30 inches; height to top of pump, 42 inches. nozzle are furnished. When crated, with eart, shipping weight is about 120 pounds. Net cash price.

$\$ 38.70$

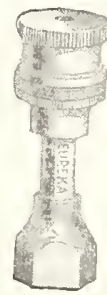

Fig. 754

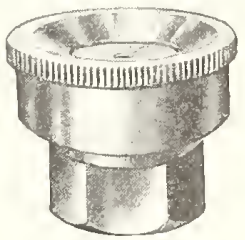

Fig. 766
Fig. 965

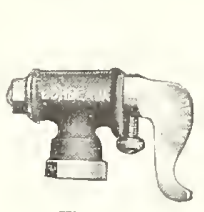$$
\text { (n) }
$$

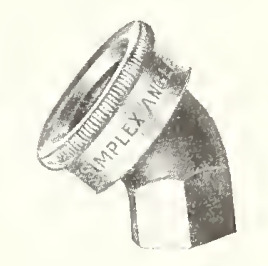

Fig. $766 \frac{1}{2}$

DEMING SPRAY NOZZLES AND ACCESSORIES

For Use With Any Make Sprayer

Parcel Post paid on all nozzles and accessories except as noted.

Fig. 965-" Bourdeaux." Best general purpose spray nozzle. Throws solid stream, fine or coarse Each, \$1.05.

Fig. 766-" Simplex." Has two interchangeahle steel spray disks, one for coarse and one for mediumne spray. Each, \$0.50.

Fig. $7661 / 2$ - Same as Fig. 766, hut with angle connection. Each, \$0.60.

Fig. 754-" "Eureka." Throws conical-shaped spray. Disgorges by pushing against fence or tree. Highly recommended for whitewashing. Each, \$0.50.

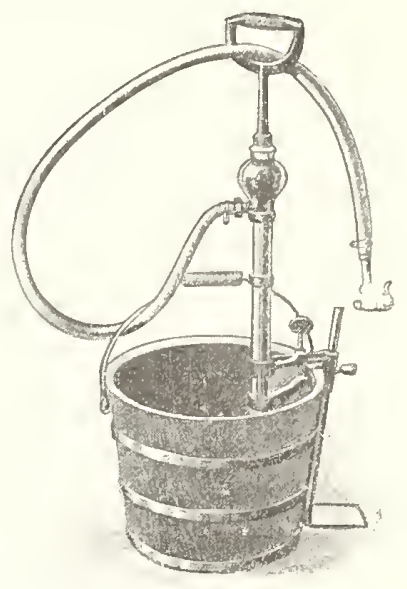

Fig. 689-THE "PERFECT SUCCESS"

The "Perfect Success" consists of the "Success" pump with malleahle iron bucket clamp and ad justahle foot rest which holds pump and bucket together, so entire outat can be carried from place to place when hucket is filled with mixture. Fou feet of hose and Bordeaux nozzle are included. Bucket is not furnished. Shipping weight, crated, 12 pounds.

Net eash price.... $\$ 7.95$ If wanted by Parcel Post, add sufficient postage for St. Louis Zone.

\section{"SAMSON" SPRAYER}

With Complete Equipment

This outfit consists of a "Samson" pump, with 50 -gallon harrel, anchored hy steel tie rods to substantial wood platform.

Pump is connected to harrel with 1 -inch suction ose witb strainer.

Mechanical agitator operates from pump lever. Filling hole with hinged cover in top of harrel. utfit may be placed in any wagon box.

Equipment includes "Samson", pump; pressure gauge; 50-gallon barrel; mechanical agitator; 1 nch suction hose and strainer; discharge "Y for one or two leads of hose; 25-foot section of $1 / 2$-inen "Deeo" sprayer hose; 8-foot extension pipe with stop cock, also ruhher hand-hold and drip shield; double spraying attachment and two illustrated above.

Shipping weight, crated, 310 pounds.

Net eash price, complete as described.

$\$ 93.75$

\section{Insecticides and Fungicides}

\section{KAYSO}

Revised Directions

Spraying authorities and commercial fruit growers in the Atlantic Coast and Middle Western States have concluded after two years' practical use and experimentation, that for hest results KAYSO should be used at the rate of $1 \mathrm{lb}$. to 100 gallons of dilute spray (2 lhs. to 200 -gallon 100 gallons of dilute spray (2 lis. to 200 -gallon
tank). This amount not only gives better spreading tank). This amount not only gives better spreading
but, by increasing adhesiveness, it makes the sprays but, by increasing adhesiveness, it makes the sprays
more resistant to weathering by rain, wind and more

$100-\mathrm{lb}$. sacks, per lb................ \$0.20

50 -lb. sacks, per lh.................... $\quad .21$

10-lb. sacks, per lb

2-lb. packages, per $1 \mathrm{lb} . \ldots \ldots \ldots \ldots \ldots \ldots \ldots \ldots$. .24

$10-0 z$. packages, each.................... Parcel Post.

BLUE VITROL (Blue-stone)

Used in making home-made Bordeaux Mixture. 450-lb. harrels, per lb................. \$0.07\%

Poison -Cannot be sent by Parcel Post.

\section{NICOTINE SULPHATE (40\%)}

For spraying Fruit Trees and Truck Crops40 per cent Nicotine guaranteed. Aphids, thrips and similar soft-bodied, sucking insects can be wiped out of the orchard or garden hy systematic spraying with Nicotine Sulphate. Being a vegetable poison it will not injure fruit or foliage.

$10-1 b$. tins. $\$ 13.50$

2-lh. tins. ..................... 3.50

$1 / 2-1 b$. tins ....................... $\quad 1.25$

1-oz. bottles...................

Can be sent by Parcel Post.

.35

BORDEAUX MIXTURE POWDER

A good many people prefer to use Bordeaux mixture for various fungous diseases for summer spraying. We recommend the use of KAYSO in combination? with Bordeaux to avoid any possi- bility of hurning foliage or staining of fruit. 100-lb. drum, per lb.............. \$0.15

4-lb. bags, per lb................. 20

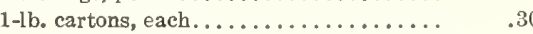

Poison-Cannot be sent by Parcel Post.

CALCIUM ARSENATE (Powder) (Same as Cal-Arsenate)

100-lb. barrels, per lh .............. \$0.18 4-lb. bags, per lh................ . .24

1-lb. cartons, eacb.

Poison-Cannot be sent by Parcel Post.

ARSENATE OF LEAD (Powder) 100-lb. drums, per lb............... \$0.20

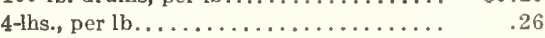
1-lh. carton, each..................... 30

Poison-Cannot be sent by Parcel Post. 


\section{GENERAL INDEX}

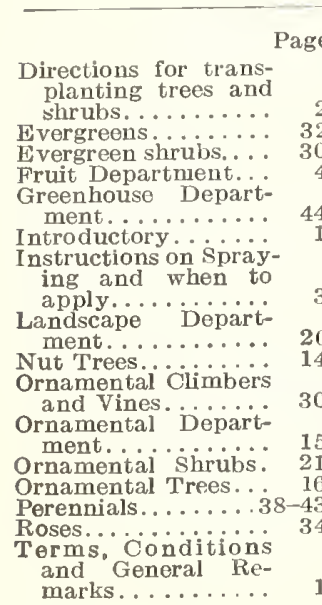

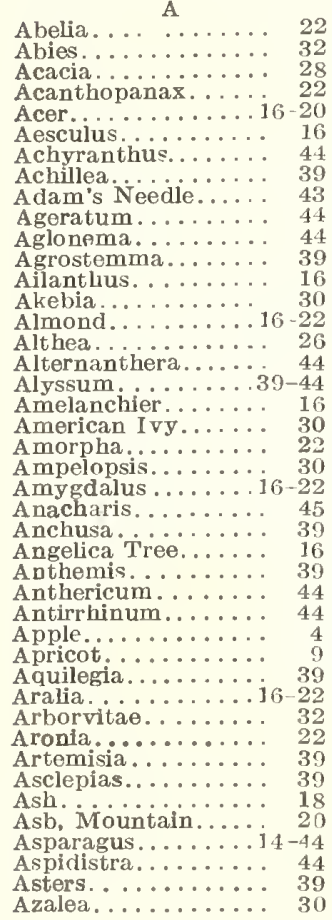

\section{B}

Baccharis.

Baby's Breath.... 40

Balloon Flower.

Barberry.

Bell Flowe.

Benzoin. .

Berberis

Betula.

Biota.............. 32

Birch. S.èt …....

Bitter Sweet

Blackberry

Blackalder

Blanket Flower.

Bleeding Heart.

Blue Fescue
Blue

Bocconia............ 3

\begin{tabular}{|c|c|c|}
\hline & Page & Page \\
\hline Boltonia & 39 & Flame Flower........ \\
\hline Boston Ivy........ & 30 & Fleur de Lis....... \\
\hline Bramble... & 28 & Floss Flower....... \\
\hline Buckthorn... . . . . . & 26 & Forsythia. \\
\hline Buddleia. & 24 & Fountain Grass..... \\
\hline Butterfiy Bush...... & 24 & Foxglove.......... \\
\hline Butterfly Wced..... & 39 & Fraxinus......... \\
\hline Button Bush....... & 24 & Funkia........... \\
\hline $\mathrm{C}$ & & G \\
\hline California Pink. . . . & 45 & Graillardia.......... \\
\hline Callicarpa.......... & 24 & $\begin{array}{l}\text { Gas Plant......... } 40-40 \\
\text { Geranium. }\end{array}$ \\
\hline Calycanthus....... & 24 & Geranium Lady \\
\hline $\begin{array}{l}\text { Campanula.......... } \\
\text { Campion......... }\end{array}$ & $\begin{array}{l}39 \\
49\end{array}$ & Washington...... \\
\hline 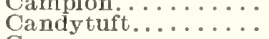 & $\begin{array}{l}42 \\
42\end{array}$ & Geum........... \\
\hline 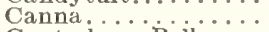 & 44 & Ginkgo . \\
\hline Canterbury Bells.... & 39 & 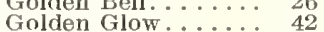 \\
\hline 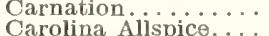 & 40 & Gooseberry............. \\
\hline $\begin{array}{l}\text { Carolina Allspic } \theta . . . . \\
\text { Caryopteris, ...... }\end{array}$ & 24 & 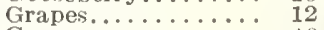 \\
\hline $\begin{array}{l}\text { Caryopteris,......... } \\
\text { Cataipa.......... }\end{array}$ & 16 & Grasses.......... \\
\hline Cedar.... & 32 & Groundsel Trec. .... \\
\hline Celastrus & 5 & Gymnocladus....... \\
\hline & & \\
\hline Cercis. & 16 & \\
\hline
\end{tabular}

Cercisanthus.

Chastise Tree.

Cherry ......... ${ }^{18}$ - 14 Hamamelis

Chinonanthus

Chokeberry....

Chrysantiemum

Cinquetoil.

Clethra.

Coleus.

Columbine.

Colutea

Cone Flower

Coniferae.

Convallaria.

Coreopsis. . .

Cornel.

Corylus...

Crab.

Crab Äpple.

Crane Bill.

Crataegus...

Crepe Myrtle..

Creeping Jcn
Crntons...

Crow Foot

Currant.

Cyperus.

Day Lily....

Delphinium.

Desmodium

Dewberry

Dianthus.

Dicentra..

Dielytra.

Diervilla.

Digitalis.

Dogwood.

Dracena.

\section{F}

Eichor

Elder....

English livy

Eulalia (grasses)

Fuonymus.

Eupatorium

Exochorda.

False Chamomile...

False Indigo.

Ferns, Hardy

Filberts

Fire Bush......... 24

Japan Quince

Juniper us

Kentia K

Kentucky Coffè 'Tree I

Kudzu Vine...... 30

Lantana.

Larkspur.

Lavender.

Lavender cotton.

Lilac

Ligustrum

Lily.

Lily of the valley.

Linden ..............

Liquidamber....... 18

$\begin{array}{ll}\text { Liriodendron . . . . . . . . } & 18 \\ \text { Locust....... } & 18\end{array}$

Lonicera. . . . . . 26-30

Lupine............... 42

Lychinis...........

Lysimachia........... 42

Magnolia M

Magnolia

Maiden Hair Treo.

Malus

Mallow

Maple........... 16 ${ }^{40}$

Maranta..........
Marigold........ 45

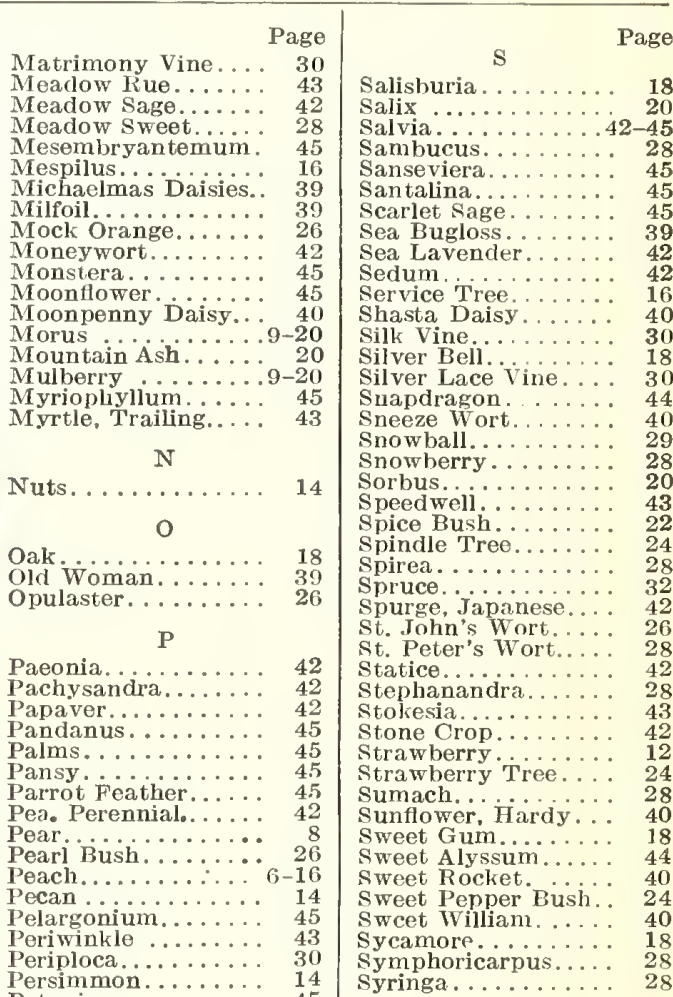

Petunia.

Pennisetum

Penstemon.

Philadelplius.

Phlox, Hardy.

Phy socarpus.

Picea.

Pine.

Pinks, Hardy Garden

Plane.

Plane.

Plantain Lily............

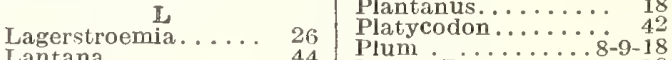

Lavendula........ 42 Poppy

$\begin{array}{ll}\text { Marguerite........... } & 45 \\ \end{array}$
Plume Poppy..... $\begin{array}{r}39 \\ \text { Plumbago . . . . } 42-45 \\ 30\end{array}$

Poplar.

Potentil

Prunus.

Pseudtsuga

Pueraria.

$\begin{array}{lll} & \text { Pyrethrum.......... } & 30 \\ 42\end{array}$

Quercus.....

$$
\mathrm{Q}
$$

Raspberry.

Red Bud.

Rhamnus....

Rhubarb...

Rhus

Ribes....

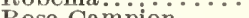

rose campion..... 39

Rose of . . ........... ${ }^{24}-36$

$\begin{array}{ll}\text { Rubus................ } & 28 \\ \text { Rudbeckia......... } & 42\end{array}$
Ranunculus age

\section{$\mathrm{T}$}

Tamarisk. .

Tamarix

Thalictru

Thuya

Torch Lily

Torch Lily

Tritoma

Truga .......

Tulip Tree.

Ulmus
Umbrella Plant......

Verbena... V

Veronica.

Viburnum

Vinca

Violets.

Virginia Creeper. . ... 33

Vitex ............ ${ }_{29}^{30}$

\section{W}

Walnut...........

Water Hyacinth.

Weeping Trees.

White Fringe........ 16

White Kerria........ 28

Willow ............ 20

Winterberry........ 26

Witch Hazel.......... 26

Y
Yarrow $\ldots \ldots \ldots \ldots \ldots$
Yucca. . . . . 39

Zebra Grass.
Tree of Heaven 
(In St. Louis County)

\section{H. J. WEBER \& SONS NURSERY CO.}

Date

Forward by

Iiail. Express or Freight

NURSERY, MO.

Please Do Not Write Here

Name

Prefix Mr., Mrs, or Miss. Write Plainly

Street, P. O. Box or R. F. D.

Post Office.

Express or Freight Office

if different from Post Office

County

State

Amount Enclosed.

State whether P. O. Order, Express Money Order, Draft, Stamps or Cast

\begin{tabular}{l|c|c}
\hline \hline Quantity & VARIETIES & Price \\
\hline
\end{tabular}

NON-WARRANTY CLAUSE. If nursery stock proves untrue to the name under which it is sold by us, a replacement of the stock, as originally ordered, without charge, or a refund of the purchase price shall be a complete satisfaction of our liability, except for such liability, we give no undertaking or warranty, express or implied, as to description, quality, growth, productiveness, or any other matter on any nursery stock we sell. We assume no liability for delays in delivery, or for nondelivery of nursery stock caused by frost, fire, flood, drought, hail, strikes, embargoes, war or other causes beyond our control delivery of nursery stock caused by frost, fire, flood, drought, hail, strikes, embargoes, war or other causes beyond our control
our responsibility ceases upon the delivery of stock in good condition. Complaints, if any, must be made within five days after delivery. Railroad, express companies and boat lines must be held responsible for losses in case of delay or damage in transit.

H. J. WEBER \& SONS NURSERY CO. 


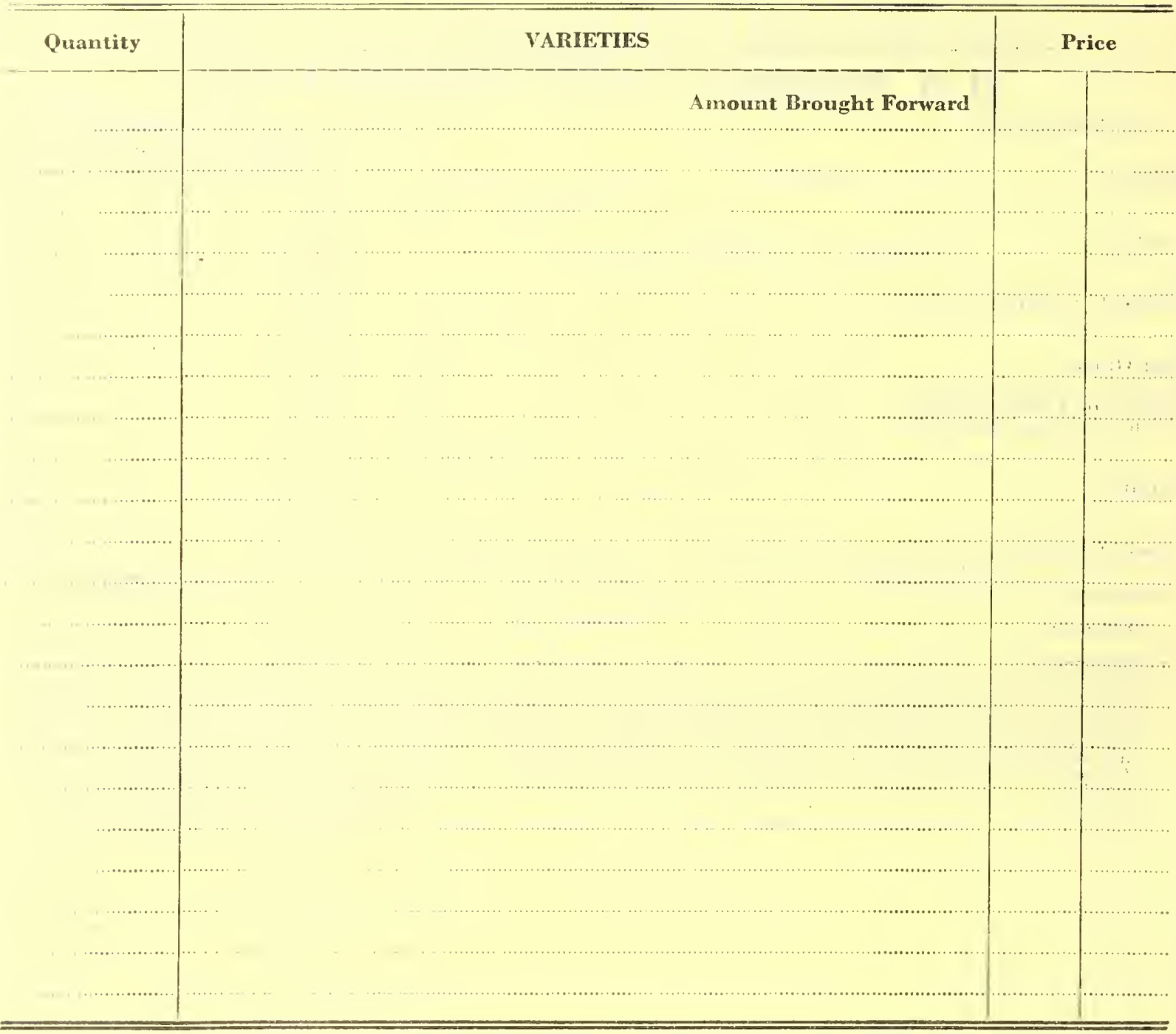

You will oblige us by sending us a few names of Friends who may be interested in our Goods. 


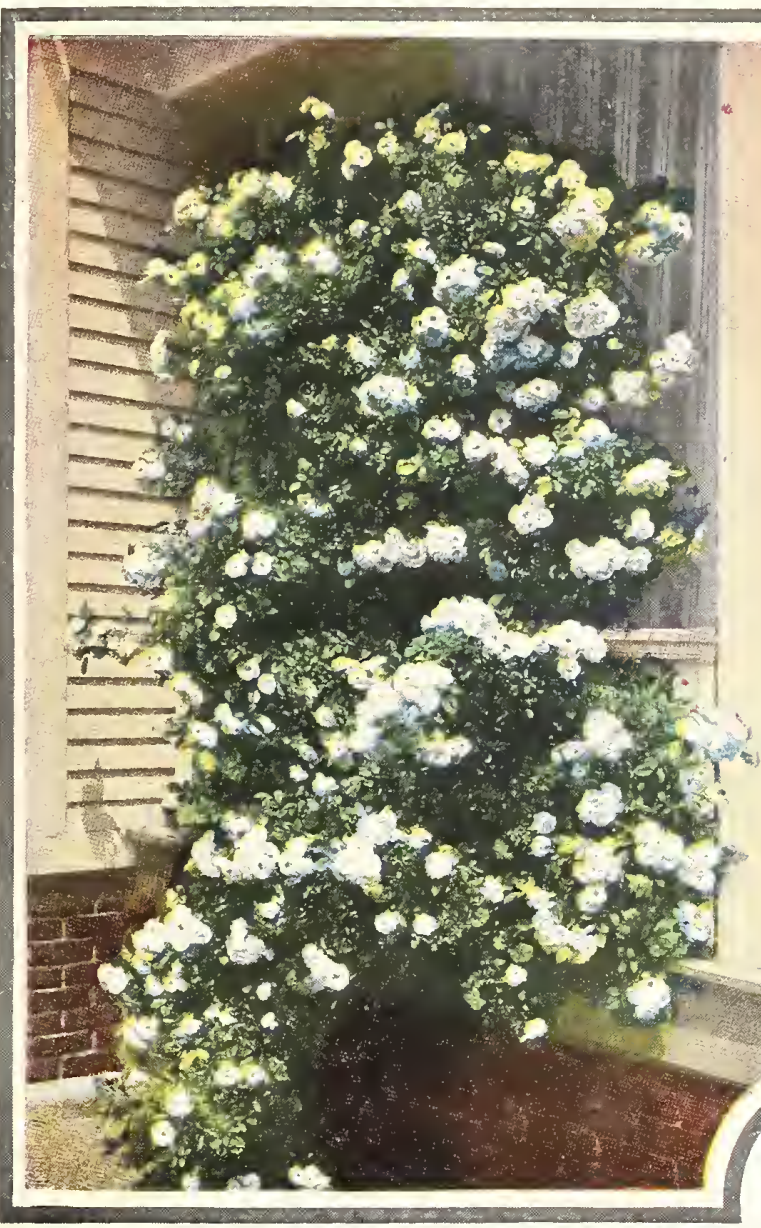
SILVER MOON

See Page 36

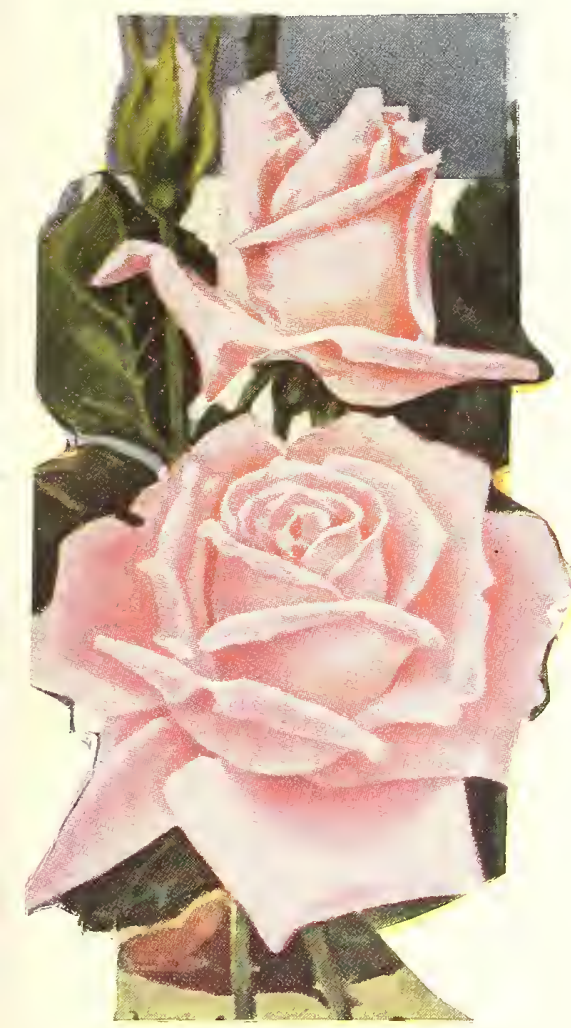

COLUMBIA

See page 36

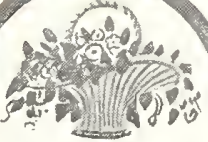

nin:

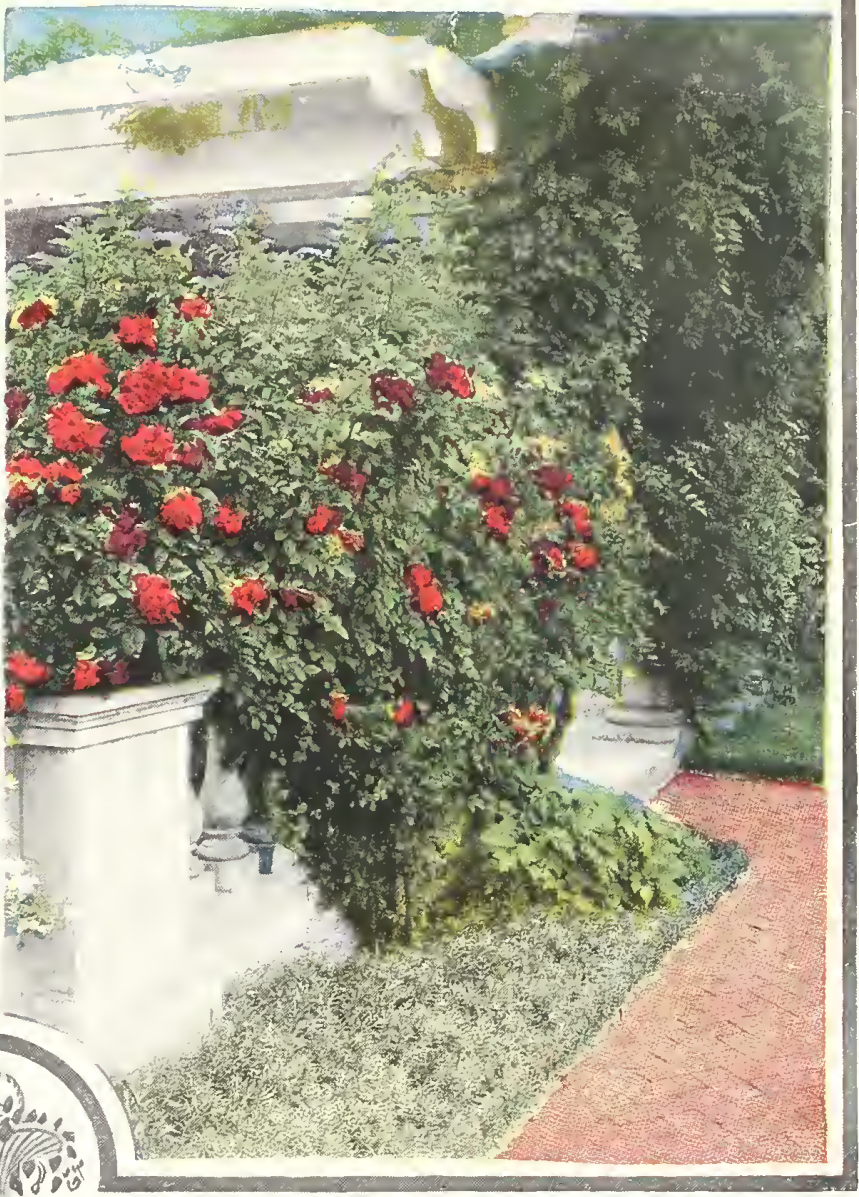

EX CELSA

See Page 36

\section{Weber's Selected Roses}

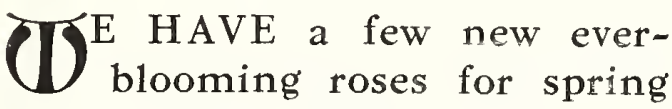
delivery-give them a trial.

SOUV. de CLAUDIUS PERNET

CRUSADER

MISS LOLITA ARMOUR

PREMIER

See Descriptions on Page 36

\section{MARY WALLACE}

NEW CLIMBING ROSE

\section{PRICE \$1.75 EACH}

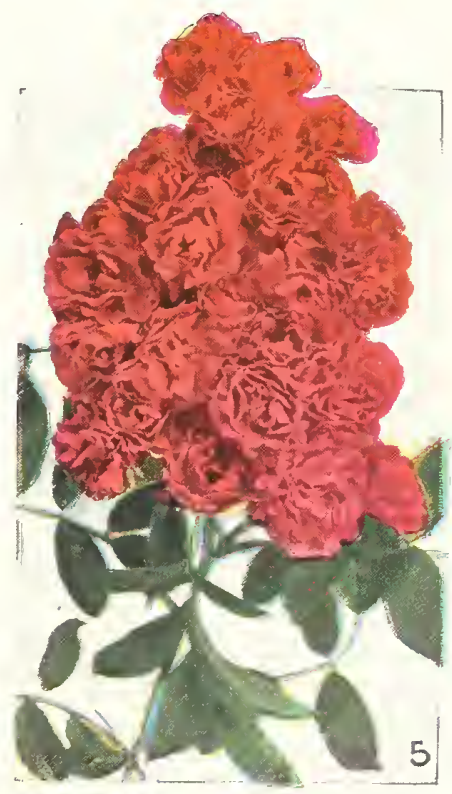

RED BABY ORLEANS 


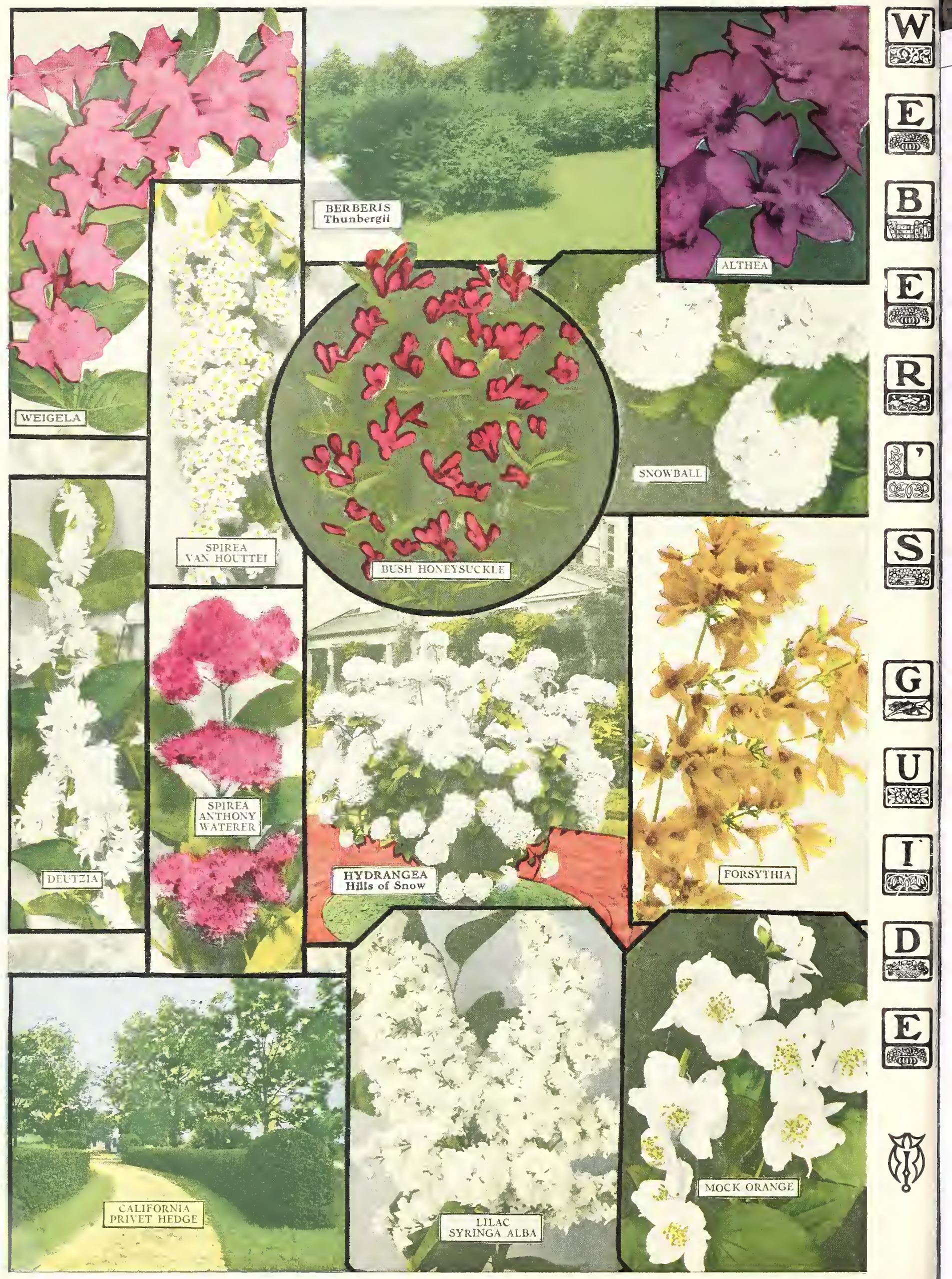

